Portland State University

PDXScholar

6-1-1972

\title{
A study of the characteristics of runaways and their families in two social agencies
}

Susan G. Greer

Portland State University

Sarah J. Hertlein

Stephen C. Regner

Follow this and additional works at: https://pdxscholar.library.pdx.edu/open_access_etds Let us know how access to this document benefits you.

\section{Recommended Citation}

Greer, Susan G.; Hertlein, Sarah J.; and Regner, Stephen C., "A study of the characteristics of runaways and their families in two social agencies" (1972). Dissertations and Theses. Paper 734.

https://doi.org/10.15760/etd.734

This Thesis is brought to you for free and open access. It has been accepted for inclusion in Dissertations and Theses by an authorized administrator of PDXScholar. Please contact us if we can make this document more accessible: pdxscholar@pdx.edu. 
( A STUDY OF THE CHARACTERISTICS OF RUNAWAYS AND THEIR FAMILIES IN TWO SOCIAL AGENCIES'

by

SUSAN G. GREER

SARAH J. HERTLEIN

STEPHEN C. REGNER

A report submitted in partial fulfillment of the requirements for the degree of

\author{
MASTER OF \\ SOCIAL WORK
}

Portland State University

1972 
TO THE OFFICE OF GRADUATE STUDIES:

The members of the Committee approve the practicum of Susan G. Greer, et al, presented June 7, 1972.

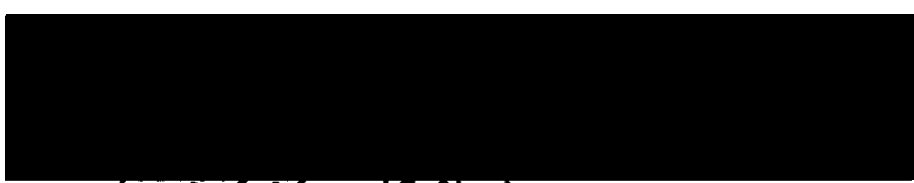

L. Jac6rnrags Chairman

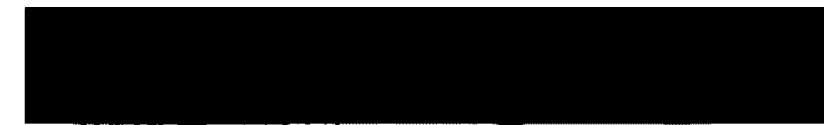

Dr. Quentin D. Clarkson

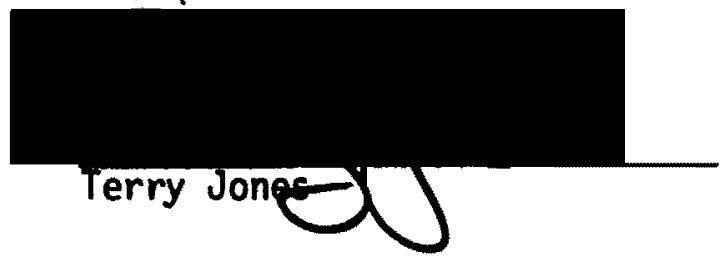

APPROVED:

Dr. Gordon Hearn, Dean of the School of Social Work

June 7, 1972 


\section{ACKNOWLEDGEMENTS}

The research group wishes to acknowledge the following individuals:

Mr. L. Jay Conrad, the Practicum Chairman, who provided a great deal of guidance and insight toward the completion of this research study. His time and support are greatly appreciated.

Mr. Quentin Clarkson, Associate Professor, who extended himself to the research group as a consultant throughout the entire study.

Mr. Terry Jones, Director of Contact Center Runaway Program, as well as the Runaway staff, who provided resource information in addition to their counseling cooperation in obtaining data.

Mr. Robert Dahl, Supervisor of Counseling Services of the Multnomah County Juvenile Court, and the participating intake and field counseling staff, without whose help we could not have completed this study.

Mr. Floyd Harmon, Cleveland High School, and Mr. Jack Ryan, Lincoln High School, for their assistance.

Ms. Carol Stone, our typist. 
TABLE OF CONTENTS

PAGE

ACKNOWLEDGEMENTS ........................ . . . . .

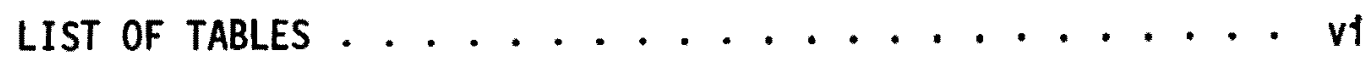

LIST OF ILLUSTRATIONS. . . . . . . . . . . . . ix CHAPTER

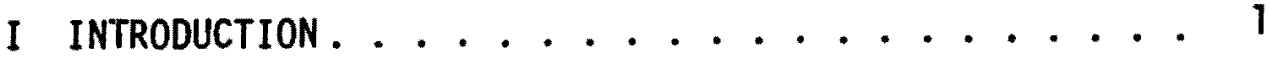

Purposes of the Study

Questions to be Studied

Definitions

Delimitations

II REVIEW OF THE LITERATURE. . . . . . . . . . 8

III METHODOLOGY .................. 25

Selection of Sample

Preliminary Survey

Final Survey

Collection of Data

Data Processing

IV PRESENTATION AND INTERPRETATION OF DATA FROM

PRELIMINARY QUESTIONNAIRE . . . . . . . . 35

Variables

Summary

$\checkmark$ PRESENTATION AND INTERPRETATION OF DATA FROM

FINAL SURVEY ................ 66

Introduction

Variables

VI CONCLUSIONS ....................... 102

Results

Impact for the Community

Implications for Future Research 
PAGE

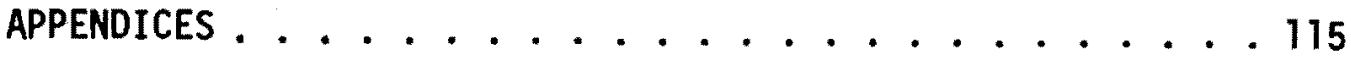

A, B, C Preliminary Questionnaire

D, E, F Final Questionnaire

G Frequency Tabulation Tables of Independent

Variable for Second Questionnaire

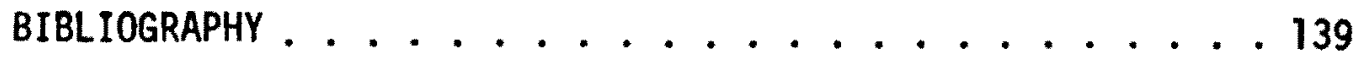




\section{LIST OF TABLES}

TABLE

PAGE

I Runaway Dispositions in Multnomah County Juventle Court According to Residency--1970

II Frequency and Percentage Distribution of Sex

III Frequency and Percentage Distribution of Race 68

IV Frequency and Means of Subjects' Ages 71

V Frequency and Percentage Distribution of School

Grade Levels

VI Frequency and Percentage Distribution of Residing Area

VII Frequency and Percentage Distribution of Marital Status of Natural Parents

VIII Frequency and Percentage Distribution of Marital

Status of Natural Parents--Married Compared to Al1 Other Categories

IX Length of Time Parents Have Been Separated or Divorced

$X$ Frequency and Percentage Distribution of Living Arrangement of Child Prior to Running Away

$X I$ Frequency and Percentage Distribution of Intact Fantly

XII Frequency and Percentage Distribution of Person

Having Legal Custody if Subject Not Living

With Natural Parents 
XIII Frequency and Percentage Distribution of Visitation With Absent Father

XIV Frequency and Percentage Distribution of Visitation With Absent Mother

XV Analysis of Variance: Subject's Feel ings Toward

Parents (or Institution) He Was Living With

XVI Analysis of Variance: How Subject Thinks Parent(s)

Feel Toward Him

XVII Frequency Distribution of Total Number of Siblings

and Percentage Distribution of Unnatural

Siblings

XVIII Frequency and Percentage Distribution of Ordinal

Positions

XIX Frequency and Percentage Distribution of Potential

Treatment of Subject in Relation to Sibiings

XX Analysis of Variance: How Subject Feels Parents

Trust Him

XXI Analys is of Variance: Subject's Trust of Parents

.XXII Frequency and Percentage Distribution of Adults

With Whom Important Matters Are Discussed

XXIII Frequency and Percentage Distribution for How Long Subject Was on the Run

XXIV Frequency and Percentage Distribution of Previous

Runaway Experiences

$X X V$ Frequency and Percentage Distribution of Event

That Precipitated Runaway 
$X X V I$ Frequency and Percentage Distribution of Previous Juvenile Court Contacts

XXVII Frequency and Percentage Distribution of Status Offense Referrals to Juvenile Court

XXVIII Frequency and Percentage Distribution of Subject Having Been in Trouble at School

XXIX Frequency and Percentage Distribution of Type of Trouble in School

XXX How Subject Feels Toward School 


\section{LIST OF ILLUSTRATIONS}

FIGURE

PAGE

I Total Monthly Referrals to Multnomah County Juvenile Court for Runaway in 1971

II Percentage and Total Number of Runaway Referral to Juvenile Court for 1967-1971

II Age Groupings of Juvenile Court and Contact Center Runaways in Preliminary Survey

IV Age Groupings of Male and Female Runaways in

Final Survey 
"If there is anything that we wish to change in the child, we should first examine it and see whether it is not something that could better be changed in ourselves."

\author{
C. G. Jung
}




\section{CHAPTER I}

INTRODUCTION

\section{PURPOSES OF STUDY}

Running away from home has always been a potential alternative for children who were unhappy, sought adventure, or simply wanted to test their ability to survive by themselves. Certainly adolescence is a critical period in one's life when considerable experimentation of new behavior takes place, usually culminating in a sense of identity for the young person. This identity is not achleved without. considerable stress and anxiety, particularly for the child and his parents. Breaking the dependent ties between child and parents, and seeking a unique identity can be a painful, difficult experience for the young adult. The achievement of independence is further complicated by parents who do not understand the process, have much different values than their child, or still need the dependent relationship of their child. What this adolescent phenomenon results in is often times the young person deciding that running away is the answer, usually temporarily, but sometimes permanently. The incidence of this behavior has undergone significant change in the past few years.

In Oregon, running away is defined as a delinquent act and comes under the jurisdiction of the Juvenile Court. ORS 419.476 states:

Children within jurisdiction of juvenile court. (1) The juvenile court has exclusive original jurisdiction in any case involving a person who is under 18 years of age and: ... (f) who has run away from his home. 
Currently, the Juvenile Code Revision Committee in Oregon is considering placing runaway acts in a separate category from delinquency. If this policy were adopted, new treatment alternatives will need to be developed to adequately handle this enormous number of non-delinquent referrals. In 1971, about $24 \%$ of the delinquency referrals to Multnomah County Juventle Court were for runaway (See Fig. I). This represents the most frequent delinquent referral to the court, and moreover signifies a tremendous social problem. In the last five $7 \%$ years, running away has increased aboutAin proportion to the total delinquency referrals to the court. (See Fig. II). Thus the evidence seems clear that this pattern of behavior is becoming increasingly frequent. Widespread publicity has been received about runaway rates soaring throughout the nation. Public reaction has been largely punitive and fearful of the potential involvement of runaways in drugs, theft, truancy, and sexual promiscuity. Because of the relative uniqueness of the runaway experience as it now exists, minimal current research information is avaflable. It was our feeling that knowledge about runaways, their families, and the social agencies which serve them is essential if significant prevention and treatment for the problem were to be implemented by the community.

The purpose and scope of this exploratory research was essentially two-fold; to contribute descriptive information about runaway youth and their families to the community, and to evaluate the current populations of two agencies which service them. An underlying goal throughout the research was to utflize the data collected to identify trends in runaway behavior, increase the potential for predictability, and provide some real insight into prevention techniques. Our informal 


\section{Figure I}

\section{0 \\ 220 \\ 210 \\ 200 \\ 190 \\ 180 \\ 170 \\ 160 \\ 150 \\ 140 \\ 130 \\ 120 \\ 110}

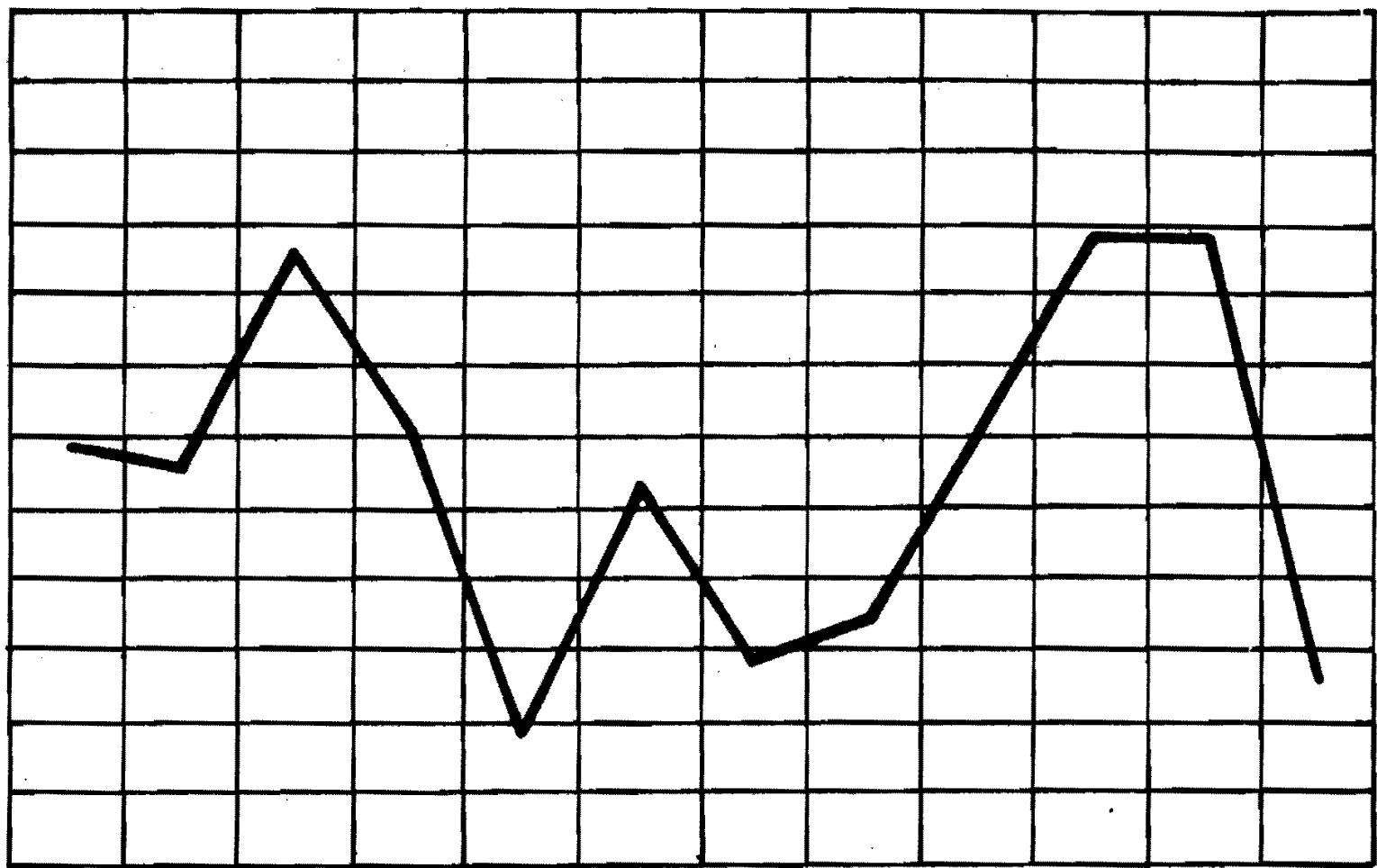

Jan Feb Mar Apr May Jun Jul Aug Sep Oct Nov Dec

Figure I reflects total monthly referrals to Mul tnomah County Juventle Court for Runaway in 1971

\section{Figure II}

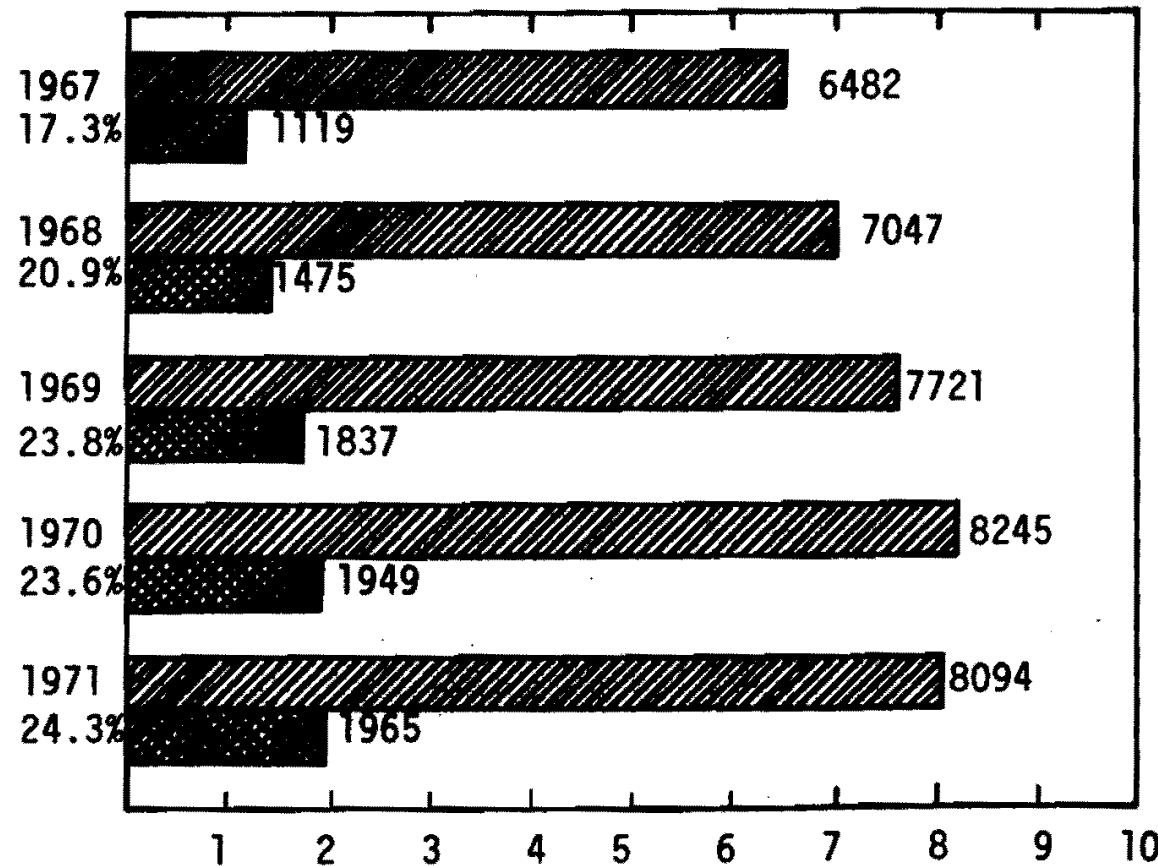

Figure II reflects the percentage of Runaway referrals out of delinquency referrals and the total number of each group for years 1967-1971 
hypothesis was that there is a significant difference in specific variables between runaway and non-runaway populations. We were interested in developing a typology of runaways, identifying those factors which increase a child's probability that he/she will run away. Finally, we wanted to know if different agencies tend to serve a particular kind of runaway who has specific characteristics. These constituted the major goals for this research practicum.

Since most law enforcement and social service energy is spent at the point of crisis, this research sought to identify trends in the scope of the problem which would aid preventative services for runaways. Hopefully, the impact of this practicum will influence crucial issues in terms of family dynamics, treatment intervention, community resources, and delinquency prevention. The results of this study will be distributed to the participating agencies and other interested segments of the community. Probably more detailed hypothesis testing will be needed; however, this study forms a base of information for future research. Better assessment of meeting the problem by evaluating all existing services should be a continuing focus for the social service community.

\section{QUESTIONS TO BE STUDIED}

Essentially, there were three basic questions which we hoped to answer from this research. They were as follows:

1. Are there significant differences between runaways and their family characteristics vs. non-runaways and their family characteristics? The specific vartables used for this question were personaldemographic data, family composition, attitudes toward famfly and 
school, parental attitudes toward runaway and non-runaway, and reported delinquency.

2. Are there significant differences between the characteristics of runaways and their families who are referred to Multnomah County Juventle Court and the characteristics of runaways and their families who seek help from Contact Center? The same variables used in Question \#1 were used in this question.

3. Are there significant differences between chronic runaways and their family characteristics vs. non-chronic runaways and their family characteristics? Again, the same variables used in Question \#1 were used in this question.

These three questions determined the research design for analysis of the data and the specific content of the questionnaires. Each question on the final survey was given statistical analysis to identify significant differences in terms of the above three questions.

\section{DEFINITIONS}

The following operational definitions were used in this research:

1. Runaway--a child between the ages of 12-18 who was referred to Juvenile Court for being a runaway, or was gone without parental permission for more than 24 hours.

2. Non-runaway--a child between the ages of 12-18 who identified himself on the questionnaire as never having run away from home.

3. Age--this was computed to the nearest year on the final survey.

4. Chronic runaway--a runaway who identified himself as having run away 3-9 times before. 
5. Non-chronic runaway--a runaway who identified himself as having run away $0-2$ times before.

6. Intact Famfly--a famfly composed of at least one natural parent and one step-parent if the other natural parent is gone.

7. Status offense--a delinquent act such as runaway, truancy, curfew, and drinking which are not criminal acts for an adult.

8. Portland Area-- the geographical area of Washington, Clackamas, and Multnomah counties.

9. Significant difference--a statistical difference which results in a .05 level of probabllity.

\section{DELIMITATIONS}

Perhaps the most difficult research to perform in the social sciences is longitudinal follow-up--a limiting factor of this research practicum. Primarily because of time limitations we could not follow our runaway population after they recelved service from the agencies studied. This type of information is crucial; further evaluative research needs to be done on agencies serving the runaway population. Also, treatment and dispositional information is only available on the preliminary survey. Due to the design of the final survey, we could not receive data related to the treatment and disposition. Comprehensive research needs to be done on this component of runaway services.

Another obvious problem with this research design is that only runaways who came in contact with Juvenile Court and Contact Center were studied. Certainly there are many runaways who never seek help from social service agencies or who have no contact with the juvenile 
justice system. What proportion of the total runaway population these agencies are actually seeing is only speculation at this point in runaway knowledge. It is entirely possible that the undetected runaway population may have unique characteristics from our sampling. A final limitation of this research is the lack of any personality assessment for the runaway and non-runaway groups. Some people have suggested emotional instability causes certain kids to run away from home. No data in this practicum can adequately answer this theory of causation. Only further exploration will solve these unanswered questions. 


\section{REVIEW OF THE LITERATURE}

Youth who run away from home are a common phenomenon in our current society. In the Washington, D.C. area alone, there are now 10,000 runaway youths per year. 1 In the Portland, Oregon area, the Multnomah County Juvenile Court recorded 1,965 runaways in 1971.2 Children and adolescents leaving home of their own accord is something that has always occurred. However, studtes concerning this phenomenon in the U.S. have mostly taken place since the 1920's. From this time to the present, many reasons have been suggested for why children run away. George Outland in 1938 predicted that the causes of running away would change:

As general conditions improve, the basic economic and social reasons for boys leaving home will be modified, the spirit of adventure will be sublimated into other channels, and transiency will tend to become more and more the wandering of the maladjusted. 3

Many of the current writers on the subject would disagree with this prediction which tends to emphasize the social and economic influence on running away. The primary purpose of most of the articles and texts to be reviewed was to discover the factors suggested as causes of adolescent running away. For this reason, organization of this section will be centered basically on those significant factors suggested as causes of youth who run away. At the time when the above statement by Outland was written, this country was just beginning to recover from the influence of the Depression. As with other runaway 
studies conducted during this decade, Outland's research focused on the economic determinants of human behavior. His study, covering the period of one year--from 1934 to 1935--dealt with the transient experiences of 3300 boys who had registered with the Los Angeles bureau of the Federal Transient Service. His data consisted of verified information from the social agencies with which each of these boys had been in contact. The author grouped the direct or immediate causes for the transiency under these general headings: economic (seeking employment, left home because of job loss, etc.), social (broken home, trouble with parents or step-parent, trouble with the law, etc.), adventure, reason connected with the army, personality defect, educational, and miscellaneous. Of the sample group, 86.7 per cent left home because of one or a combination of the first three causes--economic, social, and adventure. The primary reason for a boy leaving home was found to be economic problems: "More than 30 per cent of the families represented were active relief cases at the time the boy left home, and an additional 5 per cent had no member of the family working." 4

Another study of this same period, Boy and Girl Tramps, by Thomas Minehan (1934),5 closely resembled Outland's study. The author, from interviews with children who were on the road during the Depression years, found that 387 of the 466 boys and girls he talked to stated definitely that hard times drove them away from home. In addition to economic hardships, Minehan also included dislike of school, trouble with parents or step-parents, a desire to see the country, and the rather vague factor of "the difficulties and desires of adolescence" as other factors influencing children to leave home. 
August Aichhorn, however, took another view of transient children. In his book, Wayward Youth, $(1935)^{6}$, he does not see transiency as a phenomenon resulting mainly from economic circumstances. Instead, he includes running away with truancy and stealing and lists all three as symptoms of delinquency, like the symptoms of a disease. He states that these symptoms are "the result of psychic forces which found no socially acceptable outlet and therefore forced him [the youth] to misbehavior which was at odds with society."7 He also distinguishes between manifest and latent delinquency:

The boy who plays truant, runs away, or steals is manifestly delinquent; the boy in whom these experiences lie dormant is in the stage of latent delinquency. Suitable circumstances only are needed to turn latent into manifest delinquency. 8

A fourth, quite dissimilar view of runaway children was written during the period of the Depression by Douglas A. Thom (1932).9 This author did not consider running away either as a result of economic hardship or as a symptom of delinquency, but instead as a natural phenomenon of youth:

Every year, innumerable children "run away" for no outstanding reason. They are pushed on by the spirit of wanderlust that urges the more venturesome to seek new scenes, new faces, new experiences, and real adventure. Their running away is in no way an indication that their homes are bad or their parents unjust, or that they themselves are suffering from any particular confifct in life; it is simply an indication that they belong to that group of human being who are more concerned with having new experfences than they are with enjoying a quiet security. 10

From this statement, one would gather that the only determinant within the adolescent of running away is a spirit of adventure. Other studies by psychoanalytic authors, however, have shown that there is often important psychological determinants involved in running away. Three 
of these studies suggest that the prime cause of adolescents running away from home is an attempt to escape a supposed or a realistic incestuous relationship.

Amos Robey, et al (1964) ${ }^{11}$ in a clinical setting studied 42 teenage girls who had been referred for running away. Contacts involved one interview with the parents and at least three interviews with the subject, although treatment in some cases continued as long as two years. From these contact as well as from a review of the family's history, a pattern emerged concerning the family relationships of these girls. Significant factors in this pattern included a disturbed marital relationship, inadequate control by the parents over their own and their daughters' impulses, and a love-depriving mother who subtly pushed her daughter to assume the maternal role. These authors regarded running away by an adolescent as more than a "childish escapade." They felt it was indicative of either severe individual or family pathology, resulting from a variety of intolerable conditions within the home. The authors, therefore, conclude: "The cause most frequently observed in this study was the unconscious threat of an incestuous relationship with the father, the fear of the resultant dissolution of the family and the concurrent depression." 12

Another article by Dorothy Wylie and Joseph Weinreb (1953) 13 also establishes an incestuous relationship as the principle cause for teenage girls running away. The authors use a case example to demonstrate how treatment of the mother successfully alleviates the Oedipal conflict. It was found that this treatment of the mother, which centers on helping her recognize her own feelings regarding 
the family relationships, is more appropriate than direct therapy of the runaway girl.

Fear of an incestuous relationship is also reported as a factor in male runaways. Frederick Rosenheim (1940)14 uses three case studies to show that male adolescents run away to escape the Oedipal conflict. Dr. Rosenheim concludes: "The running away is self-banishment. . The boy cannot stay at home because of his own violent hatred, guilt and fear." 15

Because of the emotional problems facing adolescents, Herbert Staub (1943) 16 advocates that runaways should not be treated as criminals. His detailed case history of a runaway adolescent boy showed that his motives for running away came fron unresolved conflicts in childhood involving his parents. The adolescent was at the point where he was still testing his parents and searching for the "good" parent. This conflict was exhibited by his running away. An adolescent's home situation and particularly his relationship with his parents has been identified as a significant area in which friction may cause the adolescent to run away. In contrast to the previous discussion, the following studies do not specify that these parent-child conflicts stem from an underlying Oedipal wish. Lawson Lowrey 17 over a five-year period from 1935 through 1939 studied 2,756 runaways who had been given service by the Travelers' Aid, Society. The average age of the boys in this investigation was 16, while that of the girls was 17 ; it was found that boys pre-dominated at the earlier ages and girls at the later ages, yet the proportion of runaway males was greater for the total group. Although the specific method of obtaining his data is not cited by the author, he stated 
that the main reasons for running away centered around the parentchild and sibling relationships. There was often either open hostility in these relationships or a feeling of rejection experienced by the runaway. This feeling of rejection resulted either from parents who were over-protective or else psychologically neglecting of the child. Lowrey did not feel that the running away by the adolescent was particularly pathological; to the contrary he stated: "In many instances running away seems to be a healthy mode of response to an intolerable situation."18 A further comment by Lowrey regarding this phenomenon asserted:

. running away is not necessarily a complex
psychopathological phenomenon, but represents in
the great majority of cases a simple and primitive
reaction to an uncomfortable situation, the de-
tails of which are not necessarily understood
either by fhe individual or by those in the en-
vironment.

Leo Kanner (1950)20 agrees with the supposition that a runaway is responding to the home situation and also points out the significance of leaving home even to a child who has yet to attempt it:

The common, usually short-lived, escapades are immediate responses to situations evoking acute fear, anger, or spite. . . In the fantasies of unhappy children who feel neglected, unwanted, or unloved, the idea of going away often plays a considerable role as a daydream which may never be enacted. They may spin dramatic yarns around this preoccupation and, if the situation seems to become intolerable, they may actually run away. 21

The view of running away as resulting from the unmet needs of the child was put forth by Morris Reimer (1940): "The dominant perserverance and tenacity in the act of getting away suggest urgent needs which the child is striving to gratify."22 In the clinical treatment of runaway children, Reimer found that those he dealt with 
differed somewhat from adolescent runaways. The younger children usually exhibited extreme swings between unprovoked assaultive behavior and over-obedient behavior. In looking at the histories of these children, a common element of an early, extremely traumatic experience appeared:

Cruel treatment in the first years of childhood at the hands of psychotic or alcoholic parents and other terrorizing influences, such as constant fighting of parents, severe physical trauma in the form of repeated accidents or starvation, poverty or death of one or both parents, or separation of the parents, are prominent in the milieu of these chilidren.23

Reimer's explanation of the psychodynamics' involved in such families shows parents who are unable to offer spontaneous affection to their children. To counteract all the underlying needs that are not met by his parents, the child, in turn, builds a strong system of defenses by which he dentes any helplessness. These defenses are exhibited in strong negative attitudes. Reimer explains:

From a practical standpoint, the compensating reactions of the child only serve to drive him "more and more with his back against the wall," until compelled to run away from the unyielding environment and seek to satisfy that which urges him on, i.e., the need for security. The child hopes to find a new parent, one who will support and love him. 2

Because of his narcissistic needs, the child has little energy to invest in interpersonal relationships--he is thwarting his own needs even while he is attempting to satisfy them. This circumstance creates two polarities: the need for love and the need for hostile aggression. From his experience with this particular group of runaways, the author reached the following conclusions: 1) a basic factor of these children was the lack of parental love, which resulted from mismated, mentally 
i11, or inadequately adjusted parents, and 2) the symptoms of these runaway children resulted from the unmet needs for love, for hostile aggression, and for increased self-esteem. 25

Randa11 Foster (1962)26 studied the parent-child relationship and its influence on juventle delinquents, including those who had and those who had not run away. His sample of 175 consisted of children referred by a juventle court to a psychiatric clinic for treatment. The runaway sample contained an equal number of boys and girls, though the incidence of running away for girls was found to be 64.2 per cent, while it was 34.7 per cent for boys. Two groups, one of 100 runaways and another of 75 nonrunaways, were established and all subjects were seen in a diagnostic psychiatric interview. From these interviews, three areas of information were gathered: 1) demographic information, 2) information concerning the parent-child relationship, and 3) information concerning the runaway activity of the experimental group.

The author concluded from this study that there was a greater incidence of parent-child separations for the runaways as compared with the nonrunaways. This separation usually was from the father and occurred before the child was five; a reunion between the parent and child usually did not take place. There was more of ten a stepor adoptive parent in the family of the runaway delinquent than that of the nonrunaway. These families also exhibited more physical aggression and open sexual activity in the home; they tended to be more mobile than the families of the nonrunaway group. The parents of the runaway child were found to show open rejection of the child. of the runaway children themselves, there was a limited ability to express their aggressive impulses in socially acceptable ways. Truancy 
was twice as frequent in the runaway group. Punishment from or arguments with parents was the main reason given for why these children ran away. From these results, the author suggests:

It is apparent from the data presented here that the loss of a parent or the presence of a substitute parent is not in itself sufficient to determine this symptom. Nor is an intact family a guarantee that a child will not run away. These disturbances in family structure rather appear to interact with other factors, such as the degree of parental rejection and the extent of overt aggression or sexual promiscuity in the home, in the formation of this symptom. 27

Theodore Leventhal (1964)28, in analyzing the psychodynamics of runaways, emphasized the difference in the degree of "inner control" by runaways as compared to nonrunaways. HIs study involved an experimental group of 42 runaways and an equal group of nonrunaways. Through diagnostic interview data, Leventhal studied the manifestations of uncontrol in both groups of adolescents and developed a scale for rating it. His criteria for uncontrol were: 1) dischargetype behavior, such as temper tantrums, impulsivity, and enuresis, 2) deficient mechanisms that usually regulate behavior--examples of this being poor judgment and insuffictencies in cognition and mobility, and 3) a self-image of being helpless and unable to control.29 Results showed that runaways manifested more uncontrol in each of these areas than did nonrunaways; some behavior and personality traits that expressed this greater uncontrol included demanding behavior, envy, orality, stealing, truancy, irresponsibility about time, suspiciousness and poor physical coordination. Further significant points included the fact that one-third of the runaways in comparison to none of the nonrunaways, verbalized their lack of control and that in 
extended therapeutic contacts with 16 runaways, their main concern was with having little or no control over their inner impulses as well as external events. 30 Leventhal concludes:

It would thus appear that runaways, as a group, experience in many areas and for many types of stimuli, poor control. . . The danger for them is of ego loss and it has been speculated that when such a threat becomes imminent, reactions of a gross, intense, and desparate nature may appear--e.g., running away. 3

Differences within the runaway population were also significant:

-. runaways referred by police and other correctional agencies have lower uncontrol ratings than ones where parents refer themselves or are referred by nonpunitive agencies. . . Contrary to what might have been expected, the police referrals seem to have less difficulty with control than the other runaways. 32

A specific type of runaway--the runaway foster child--is considered by Joseph Paull (1956) 33 . He notes that the dynamics of such a child are different from one who is in his own home. The reason for foster children running away, he suggests, is because of their inability to accept a substitute home and substitute parents.

A study conducted by Lawrence Bradshaw, et al, $(1969)^{34}$ in Salt Lake County, Utah, showed that 30 percent of all referrals to the juvenile court in that county were for running away. From a sample group of 80 taken from these runaway referrals, it was found that 60 percent had a previous record at the juventle court. Events precipitating the running away usually fell in three areas: trouble with parents or foster parents, trouble at school, or trouble with relatives. Seventy-five percent of the time problems in the home was the reason for running away. Although a vast majority of the sample (85\%) said they ran away because of a personal problem they had for six months or longer, sixty-three percent felt they had not been helped in resolving 
these problems.

There are several studies concerning runaways that propose that runaway behavior can be used as a predictive tool of delinquency. One of these is James Hildebrand's study $(1963)^{35}$ in which he asserts that runaways for the most part represent youth who have a problem, but in most cases have not developed a definite anti-social attitude. The author feels that such behavior has great significance in terms of further acting out and should be recognized as a danger signal in attempts to control crime. This study involved 262 runaway cases reported to police in a section of Brooklyn, New York, and was concerned with investigating four areas: age distribution, recidivist patterns, length of time away from home, and motivation for leaving. It was found that in this study the frequency of boys to girls running away was equal. It was also found that boys run away at a younger age and that this behavior peaks at age 14 to 15; for girls the rate of running away increased until age 17 . The recidivist rate showed that boys repeatedly ran away at a younger age, usually around 12, while girl repeaters increased as their age increased. Until age 12, most runaways stayed away from home for one day or less; the length of time away increased as the runaway's age increased.

Motivation for running away was found to be the most difficult factor to determine. Rather than one isolated cause, there were exhibited a variety of factors that interacted to cause the running away. The most influential of these was a poor home environment--a large part of which was lack of family discipline. A second factor was school; difficulties in this area were exhibited by truancy, poor grades, and misconduct. The author notes that in most cases of 
runaways, their parents expressed complete ignorance as to why their children ran away. If they did affix blame, it was to the school or the neighbor's children. Hildebrand concludes that running away is a strong indicator of problems within the family and as such should prompt intervention to solve the problems before they are acted out in criminal behavior.

A study by Ivan Nye and James Short (1957) ${ }^{36}$ also designates running away as a behavior that implies future delinquency. With a total sample of 2,350 , these investigators attempted to develop a delinquency scale. The sample population included normal high school students from two sections of the country as well as residents at a boys' training school. They constructed an initial list of 21 items of criminal and anti-social behavior. Running away was found to be the first item on the scale that occurred in less than 10 percent of the high school population, while it occurred in 61 percent of the training sichool population. Running away, then, formed the cutting off point between these two populations and appeared to be a significant behavior problem that was highly related to serious delinquent behavior in boys.

In a 30-year follow-up study, Lee Robins $(1958)^{37}$ investigated the psychiatric status of 179 male patients who were seen at a child guidance clinic as children and interviewed 30 years later. Of the 179 sample, 56 had a history of running away from home. The other male patients had childhood problems that did not include running away. Based on the Nye and Short study, the author makes the following statement: "Running away was chosen as the behavior problem to study because it promised to select a group with a serious degree of antisocial behavior in childhood." 38 Results showed that in comparison 
to normal control subjects and to the male patients who did not run away as children, the adult who had run away as a child had a higher rate of psychiatric 111 ness. Those who had been runaways also had a higher incidence of delinquency and reformatory experience. In comparing runaways to nonrunaways according to juvenile offenses, runaways again showed a higher rate of psychiatric illness. Robins, therefore, points out that runaway behavior is predictive of later mental illness even when the high rate of delinquency and reformatory experience is taken into account.

A joint report of Robins and Patricia $0^{1}$ Neal (1959) ${ }^{39}$ continued to study the rate of adult deviance among mental patients who had run away as children as compared to those patients who had not. The sample of 246 patients included 96 patients with a runaway history. The criteria for measuring the patients' adult deviance were 1) arrest and prison records, 2) divorce rates, and 3) current psychiatric diagnosis. Findings from this study showed that those with a history of running away had more adult arrests and were incarcerated more often than those who had not run away; over half of the runaway subjects had been divorced at one time. In terms of psychiatric diagnosis, the runaway patients were most often diagnosed sociopathic personality, a diagnosis characterized by continuing anti-social behavior. The authors conclude:

... while running away does not predict adult adjustment when juvenile offense history is controlled, taken as a single index of adult adjustment, it is an excellent prognostic tool. Therefore, it would be useful in making predictions about the future of children for whom running away is a first offense, before the total juvenile offense pattern has unfolded. 40

In an intensive study of runaways by Robert Shellow, et. al, 
(1967) 41 , the authors comment on previous studies that have attempted to designate running away either as an act of delinquency or as a result of personal psychopathology. They feel that this either/or position results from the type of agency from which the experimental group was selected. Whether the agency involved was a correctional institution, a mental health facility, or welfare services influenced the outcome of the research. In order to eliminate this bias in their study, the researchers chose a sample from a more general group--776 youths reported missing to the police over the period of one year. To further prevent bias, they made the contacts themselves with the youth and their parents rather than through police personnel. A summary concerning the runaway activity of these youth shows that they traveled a short distance, rarely getting beyond their own metropolitan area, stayed away only briefly (in two-thirds of the cases, the episode had ended within 48 hours), and returned frequently of their own volition. There was an equal number of cases in which children ran away alone or ran with compantons; perhaps because of the dating situation, the researchers found that girls were somewhat more likely to run away with someone else.

Other factors of the runaways included a socioeconomic and educational background of their parents that was compatible with the general community in which they lived, but a greater proportion had broken homes than did nonrunaways. Two-thirds of the parents of the runaways stated that their children experienced trouble in school. A student questionnaire to a control group, however, showed the same proportion listing problems in school. The significance may have been in the 
degree of these difficulties: ". . school records show that runaways, in contrast to other adolescents, were absent more often, had lower grades, and were more likely to have been retained." 42

Those adolescents who had not run away were asked if they had ever seriously considered doing so. Of these, one out of three said yes. The authors caution, therefore, that it may be difficult to designate clear-cut differences between runaways and nonrunaways since a deciding factor may be the immediate circumstances of the adolescent which causes him to run away.

The authors did feel that from the data they gathered this runaway population could be separated into two groups. They state that the first group ". . . was a relatively small group for whom running away was intimately bound up with individual or family pathology. "43 The second group which was much larger included some repeaters, but mainly those who had run away only once. This group, although showing some differences, more closely resembled the nonrunaway group rather than the seriously disturbed of the first group. A recomnendation from this study states that when planning treatment for runaway adolescents, both groups should be kept in mind--the first group being treated for the severity of their problem and the second group in ways similar to normally troubled adolescents.

In Larry Begg's Huckleberry's for Runaways $(1969)^{44}$, he cites as the primary reason for running away the adolescent's attempt to draw attention to the home situation; it is a plea for help. He further explains that what motivated the runaway is usually a family problem rather than just a personal problem. By running away, the adolescent challenges his parents' and the school's assumption that everything 
is alright. In order to help parents and runaways work on the problems, intervention (as well as shelter for the runaway) is provided by the staff of this runaway house in San Francisco.

Another example of the same type of intervention is offered at Runaway House in Washington, D.C. In dealing with a portion of the 10,000 yearly runaways in this area, David Riley $(1971)^{45}$ found that an outstanding characteristic of these children was the high rate of family mobility. The author of this article feels that running away is basically a middle-class phenomenon. The runaways whom he serves usually left home because of fights or misunderstandings concerning their friends, the clothes they wear, or the style of their hair. Riley pursues underlying reasons, however, and asserts that the suburban syndrome is a life style that brings about many 111 effects:

If we are to understand why our kids are running away and what they are running from, we will have to think about a lot more than just family problems, tortured and complex as they are. We will have to look at the status rat race of fancy cars and manicured lawns and we will have to create communities that break down the isolation felt by so many parents and children. We have to encourage human contact and warmth between families, as well as within them. He will probably have to trans form the whole American ethos. 46

Two other articles in the popular press 47 are concerned with law enforcement contacts with runaways in metropolitan areas. Both articles point to a lack of parental guidance or inadequate values in the home as forces which push adolescents to seek another life style. These runaways, then, are viewed as leaving home in search of something, while several of the previous studies have suggested that running away is a temporary plan with the adolescent that he hopes will focus attention and perhaps change his home situation. 
A summary of the studies reviewed shows that a variety of reasons have been cited for adolescents running away; some of these are incestuous threats, poor relationships within the family, the hope of drawing attention to troubles at home, a natural reaction to an uncomfortable situation, and a spirit of adventure. As the runaway studies have occurred since the 1920 's and 30 's to the present, the causes stated for running away have shifted from being primarily designated as economic to reasons with a more social and psychological emphasis. The more current literature shows that problems within the famtly are more often the cause of running away rather than the individual pathology of the adolescent. In terms of methodology employed in these studies, it appears that in the majority of instances data was either obtained through interviews with the runaway or from case histories from psychiatric clinics or other social service agencies. An important use of the runaway data for predicting future acting out behavior has been pointed out. That no one factor has been isolated as the prime determinant of running away appears quite evident from the material presented. 
CHAPTER III

METHODOLOGY

\section{SELECTION OF SAMPLE}

Multnomah County Juvenile Court and Contact Center were selected to provide data from the runaway population because these agencies are two of the primary resources dealing with the runaway problem in the Portland Metropolitan Area. Furthermore, they represent a wide range of potential approaches to the runaway phenomena. Juvenile Court is representative of the traditional, law enforcement approach to handling delinquency, where the young offender is subject to detention, required counseling, and court intervention. Contact Center, on the other hand, represents the trend to more communtty-based soctal service to adolescents by young para-professionals. This new approach allows the young person more independence and operates in an advisory model, rather than a legalistic structure.

Multnomah County Juvenile Court is the major social agency handling runaways in the Portland area. Services include an intake section, a counseling section of about 30 staff, and a detention facility composed of three girls' units and four boys' units. Referrals come primarily from the police, with others coming from parents, schools, and other agencies. At the time of this research, a district office had been recently established in the Multi-Service Center in North Portland, with other district offices planned. Referrals to the court may be handled either formally or informally. The large majority of 
runaway cases are handled informally; the disposition is usually warning and closing the case, or informal supervision. Some chronic runaways are required to have a formal hearing before a judge, and this results in formal probation or committment to other institutions for some. Table II details the runaway referrals for the last five years, with $24 \%$ of the delinquency referrals for runaways in 1971.

Contact Center is a non-profit organization, known legally as the Portland Youth Advocates. Several members of the local community compose the P.Y.A. Board of Directors. Contact Center is located in the Koinonia House on the campus of Portland State University. Four programs comprise the Contact Center currently: the Drop-In Center/Streetwork Program, Open Meadow (an alternative school), a Group Home for adolescents, and the Runaway Program. In July, 1971, the Runaway Program received funding from the Law Enforcement Assistance Administration for counseling staff, a program director, and operational expenses to implement a treatment home for runaways. This crisis home, out Front House, is located at 928 SE 18th. The runaway staff is a group of para-professionals with considerable experience in relating with adolescents. Prior to July, 1971, no formal data or records had been kept on the runaways which Contact was seeing. Thus there is no comparative data for earlier time periods. Referrals come primarily from the runaways themselves, either by phone or in person. No action is taken to help the runaway resolve the problem unless he/she wants Contact to intervene. This self-referral process and non-legalistic approach makes Contact Center a unique resource for runaways. Working agreements are established with Juvenile Courts and Children's Services Divisions in the Portland Metropolitan Area. Contact may work with 
agencies which the runaway already has involvement, provide counseling and foster placement if needed, place in Out Front House for treatment, or simply give advice if the adolescent does not want formal help. Currently, the Runaway Program is seeing about 35 new runaway youths per month.

The non-runaway group was selected from Cleveland and Lincoln High schools on the preliminary survey, and only Cleveland High School on the final survey. It was felt that these two schools contained a good cross-section of adolescents in terms of race, socio-economic status, and family characteristics. Because of convenience, Lincoln was eliminated from the final survey without jeopardizing the cross-sectional sample significantly. Thus the control group for the final survey was comprised entirely of Cleveland High School students. Lincoln High School is located at 1600 S.W. Salmon in downtown Portland and has approximately 1,200 students. Cleveland High School is located at 3400 S.E. 26 th and has approximately 1,875 students. Most high school students in grades 9-12 are from ages 14-18.

\section{Preliminary Survey}

In the sample of 25 from Contact Center, questionnaires were gathered from the time period of June 1 to September 15, 1971. In this $3-1 / 2$ month time period, the majority of questionnaires received were used, with some being eliminated because of a lack of complete information, and not meeting our operational definition of runaway. Runaway counselors were instructed to administer the questionnaire as part of their intake session, but it was noted that some of the runaways completed the questionnaire themselves. It was felt that this inconsistency did not seriously affect the data. This population was 
not a randomized sample, since most runaways for this time period were included.

The sample of 16 runaways from Juvenile Court was based on voluntary participation from 7 counselors, one of whom was based at the Multi-Service Center field office in North Portland. Only 6 of the original counselors actually provided questionnaires used in the sample, and the distribution of the 16 runaways was not proportionate to these 6 counselors. Although haiff of these 6 counselors were female and half were male, $75 \%$ of the runaways in this sample were handled by female counselors. Since girls are usually assigned to a female counselor, this affected the sex distribution of our runaway sample. Furthermore, these 16 runaways used in the sample were only a portion of the total runaway cases which the counselors had during the time period of July 1 to September 15, 1971. While we had projected about 49 runaways for 7 counselors in this time span, 56 were actually assigned to the selected counselors. Table In details the 1970 runaway referrals to the court, according to dispositional records and gives runaway data for the selected time period. A sample of at least 30 was advised to perform valid statistical tests. Needless to say, the projected sample fell considerably short of the goal. Counselors at the court are given cases by high school district; thus we had six districts represented. This population was not a random sample because of the uncontrolled exclusion of most runaways from the sample.

The sample of 45 non-runaway adolescents was surveyed in June, 1971, by the research group at Cleveland and Lincoln high schools. 


\section{TABLE I}

Runaway Dispositions in Multnomah County Juventle Court According to Residency

(1970)

Portland 714

Multnomah County excluding Portland 245

Total Mul tnomah County 959 959

Other Oregon counties 343

Out of State 332

Unknown

Temporary Welfare Conmittment 808

Other Geographical Areas 1484 1484 Total Runaway Dispositions

(Since about $40 \%$ of the runaway dispositions were Multnomah County residents, we had projected that the total "in-county" runaways for 1971 would be about 800 . Assuming small seasonal fluctuation in the number of referrals, it was anticipated that the counseling section would receive about 67 runaway referrals per/month. Each counselor at Juvenile Court should recefve about two runaway referrals per/ month for 1971.) 
The students completed the questionnaire themselves, and forms were checked randomly as they were turned in. The sample was taken from English and Social Studies classes to be unbiased in terms of tract classes or interests and included 25 Freshman students and 20 Sophomores. All youths answering the question about prior running away as "Yes" were eliminated from the sample. Nearly half of the total questionnaires received were excluded because of prior running away or incomplete information. There were about twice as many girls in the total sample as there were boys; this tended to skew the sex distribution. This population was again not a random sample because of the uncontrolled exclusion of many students from the sample.

\section{Final Survey}

In the sample of 21 from Contact Center, questionnaires were gathered from the time period of December 1971 to February 1972. During this three month time period, many questionnaires had to be eliminated because of incomplete information. Runaway counselors were again instructed to administer the questionnaire, and this policy seemed to be followed. Because of the exclusion of many runaways, this population was not a random sample.

The sample of 50 runaways from Juvenile Court were taken in the months of January and February, 1972. Because of our earlier experience and difficulty in obtaining data from the court, we chose to sample the runaways coming to the intake section and detention, rather than the counseling section. This included out-of-county runaways in our final survey. Most of the runaways included in the sample had stayed in detention. Thus this sample of runaways were not necessarily Multnomah County residents, and not necessarily referred for counseling. 
Because of the nature of this methodology there was not available any dispositional information so that this factor was eliminated. Questionnaires were administered by the intake staff and the research group, with the runaway filling out the questionnaire himself. The total of 50 runaways was a small percentage of the total runaway referrals to the court during this time. The sample was also not random because of the uncontrolled exclusion of many runaways from the population.

The sample of 34 non-runaways from Cleveland High School was surveyed in February, 1972. The students completed the questionnaire themselves, and forms were checked randomly as they were completed. The sample was again taken from a combined Social Studies and English class over two periods of the day to be unbiased in terms of tract classes or interests. As with the preliminary survey, freshman high school classes were chosen because of the age distribution. 13 of the total questionnaires received were excluded because of prior running away or incomplete information. This population was again not strictly randomized because of the uncontrolled exclusion of many students from the sample.

\section{COLLECTION OF DATA}

Data was collected by the use of a two-page research questioninaire in all phases of the practicum. Appendices $A, B, C, D, E, F$ detail the six questionnaires used. Generally, the preliminary survey was used as a pre-test for the questionnaire. It was felt that a better research instrument could be achieved if a preliminary sampling were done. Also, by using a preliminary survey, significant factors concerning runaways and non-runaways could be identified and more attention given to these 
factors in the final survey. Open-ended questions were mainly the focus of the preliminary survey since all possible responses were needed to develop a more specific questionnaire in the final survey. It was decided after assessing the preliminary survey that attitudinal questions (ones which described feelings) would be better treated by the use of a numerical scale. Some questions were completely eliminated from the final questionnaire, while others were expanded in much more detail.

The preliminary questionnaire was developed by the research group and the participating agencies' staff. Approval and cooperation of the Juvenile Court administration was obtained initially. Following this, meetings were held by the research group with Contact Center staff and Juvenile Court counselors to gain input from the agencies in deciding the format and nature of the research instrument. Once the questionnaire was developed, additional meetings were held to orientate the participating staff members in the composition of the questions and the manner of administering it. It was planned that the questionnaire would be completed by the counselor as an integral part of the intake process rather than having the runaway confronted by the research group at a time of crisis. Much attempt was made to have a questionnaire which was easy to administer and would generally gain information needed in the interview process. In the final survey, the composition of the final questionnaire was developed exclusively by the research group.

It should be noted that a few inconsistencies appear in the collection of data. First, on the preliminary survey, court runaways were not asked about the nature of previous referrals to the court, 
while other sample groups were. Also in the preliminary survey, there were several questions asked of Contact Center runaways which were unique to that agency and were done mainly at the request of the agency. Finally, the question about welfare on the final survey was inadvertently left off the Juvenile Court questionnaire.

\section{DATA PROCESSING}

Data in the preliminary survey was not processed by data cards. The research groups hand-sorted and compiled all information since many open-ended questions did not lend themselves well to data processing. In the final survey, questionnaires were collected and a code sheet developed. Once the code sheet was typed (See Appendix G), al1 questionnaires were coded on an IBM Coding Form, and organized into the three population groups. Then coding forms were given to the Portland State Computer Center for key punching and proofreading. This resulted in 105 computer cards representing all questionnaires. The research group then sorted the cards for a count of all frequencies for each question by the use of an IBM Card Sorter. After looking at the data, the idea of setting up a chronic and non-chronic runaway study was formulated. We split the runaway population in half as nearly as possible in terms of the number of times they had run away. This resulted in our operational definition of chronic ( 3 to 9 times) and non-chronic (0 to 2 times). The runaway cards were then sorted again for all pertinent questions, and frequency counts made. This made a total of five population groups of data. 0ther card sorts were done when certain comparisons required isolating some factors. No further data processing or programing was necessary because of the relatively simple statistical testing which our data 
required. The majority of statistical testing consisted of Chisquare analysis, with some $F$-tests and t-tests performed on continuous variables and population means. Data processing techniques and statistical testing required appropriate research consultation. 


\section{CHAPTER FOUR \\ PRESENTATION AND INTERPRETATION OF DATA \\ FROM PRELIMINARY OUESTIONNAIRE}

In this section the results of the preliminary survey of runaways at Contact Center and Juvenile Court, and the non-runaway control group are discussed in terms of:

1. demographic characteristics,

2. previous referrals to Juvenile Court,

3. school experiences,

4. family and other significant relationships,

5. the runaway experience,

6. service wanted from the respective agencies, and

7. the final or anticipated disposition of the case at the time the interview was conducted.

As the preliminary survey was designed as an open-ended probe for dependent relationships that would distinguish runaways from nonrunaway youth, standard statistical testing was not performed on the data. Percentage figures that identified areas of considerable difference in responses of the three sample groups were included in the discussion.

$\underline{\text { Sex }}$

Usable responses from the first questionnaire were obtained from a significantly larger number of females than males in both the control and experimental groups. The predominance of females in the runaway group can be attributed to several factors: 
1. A bias in the sample reflecting a distortion resulting from the fact that this pahse of the study was completed in a limited time period.

2. An upward trend in the number of females being referred to Juvenile Court for runaway behavior. The slight increase in the total runaway referrals for 1971 (.8\% greater than 1970$)$ is due to an increase of 109 female referrals; in the same year male runaway referrals dropped by 93 .

3. A sampling procedure at Juvenile Court which relied upon counselors wishing to volunteer their assistance in the research project also contributed to the bias in sex distribution. Four of the seven counselors who volunteered to administer questionnaires were women. The Juvenile Court policy, in most instances, is to refer runaway girls to women counselors and boys to men counselors within the high school districts to which they are assigned. Therefore, it could have been anticipated from the constraints of our sampling procedure alone that a larger number of females would be included. In addition, two of the male counselors at the court remarked that during the sampling period referrals to them had in general dropped and, in particular, runaway referrals.

In regard to the control group, an effort was made to draw a high school sample that would avoid bias associated with special tracking and elective courses. However, the general required classes that were selected for the control population had over twice as many females as males in attendance when the questionnaire was administered. Of the 87 questionnaires that were returned about half were eliminated 
from the sample because of incompleteness or previous runaway experiences. It should be noted that of the four high school classes which supplied the non-runaway control group, almost $20 \%$ (16 out of 87 ) of the youngsters were eliminated because they had run away from home before.

\begin{tabular}{lccc}
\hline Sex: & Contact & JDH & Control \\
\hline Males & 10 & 4 & 7 \\
Females & $\frac{15}{12}$ & $\underline{12}$ & $\frac{38}{4}$ \\
Tota 1 & 25 & 16 & 45 \\
\hline
\end{tabular}

Age

The mean age of youth in both the control and the two experimental groups was approximately 15 years. Runaways at Juvenile Court averaged 14.75 years, Contact Center runaways averaged 14.76 years, and the non-runaway subjects' mean age was 14.96. Seventy-five percent of the total sample of runaways were 15 years of age or younger. Contact Center and Juvenile Court runaways were compared in terms of the ages at which runaway rates were highest. Runaways from Contact Center peaked in frequency at age 15 while Juvenile Court referrals were most numerous at age 14 and declined rapidly thereafter.

\begin{tabular}{lccc}
\hline Age: & Contact & JDH & Control \\
\hline 12 years old & 2 & 0 & 0 \\
13 & 1 & 2 & 0 \\
14 & 7 & 6 & 14 \\
15 & 9 & 4 & 19 \\
16 & 3 & 2 & 12 \\
17 & $\frac{3}{25}$ & $\frac{2}{16}$ & $\frac{0}{45}$ \\
Totals & $\frac{1}{25}$ & & \\
\hline
\end{tabular}


FIGURE III

Age Groupings of Juvenile Court and Contact Center

Runaways in Preltminary Survey

Number

of

Runaways

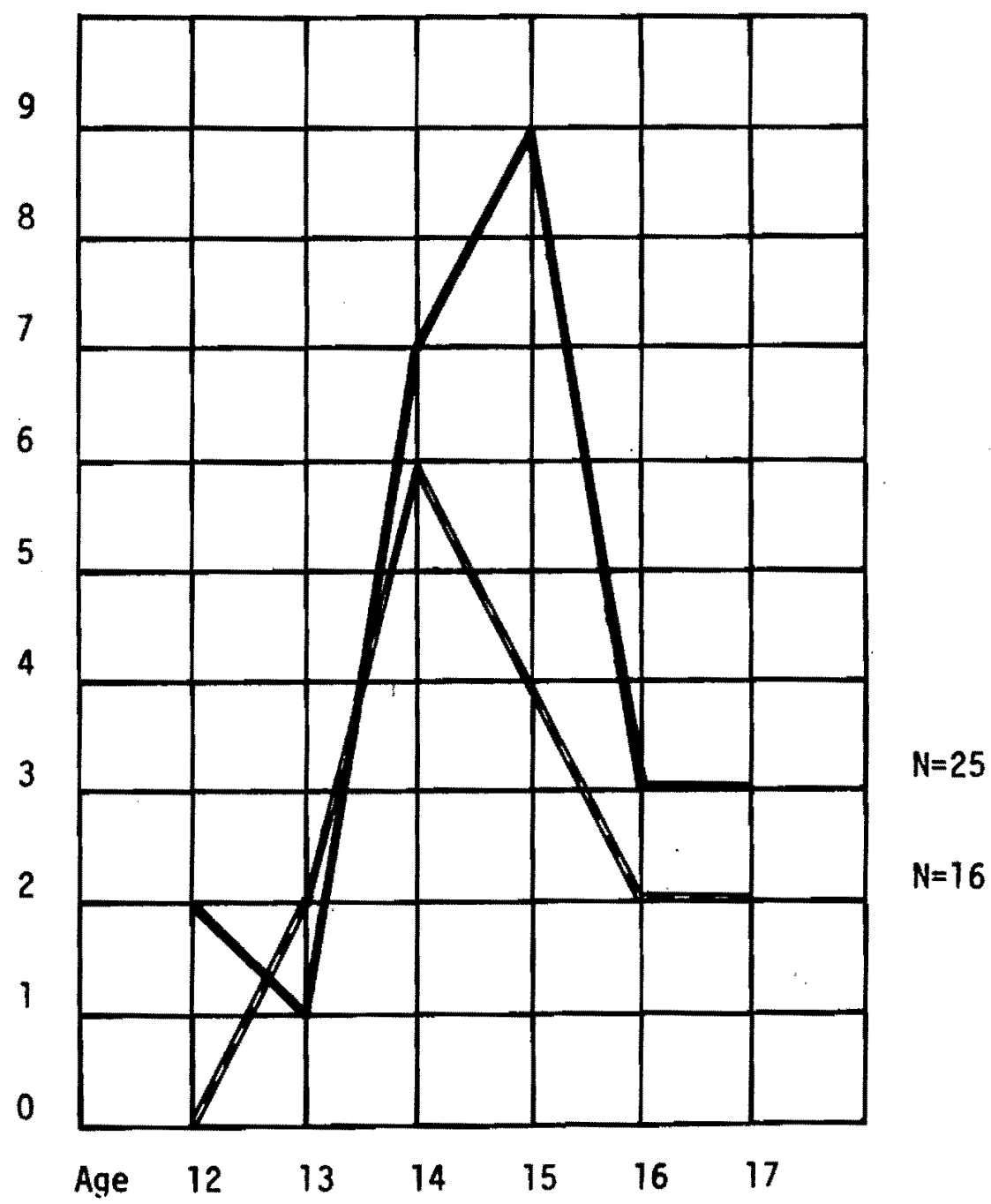

Court

Contact 
Ethnic Grouping

The runaway sample for the inftial questionnaire was predominantly Caucasian. Contact Center had 21 or $84 \%$ Caucasian runaways, plus two American Indians and one Spanish-American youngster. No information was avallable on one subject. The majority of runaways at Juvenile Court were also Caucasian: 13 out of 16 runaway referrals or $81 \%$ of the sample. Two court runaways were $B 1$ ack and one was of mixed racial background. Of the 45 high school students in the control group, 44 were Caucasian and one was Oriental.

\begin{tabular}{lccc}
\hline Race: & Contact & JDH & Control \\
\hline White & 21 & 13 & 44 \\
Indian & 2 & 0 & 0 \\
Black & 0 & 2 & 0 \\
Oriental & 0 & 0 & 1 \\
Chicano & 1 & 0 & 0 \\
Indian/French & 0 & 1 & 0 \\
Unanswered & 1 & 0 & 0 \\
Total & 25 & 16 & 45 \\
\hline
\end{tabular}

\section{Marital Status}

In less" than half of the homes of both runaway samples were natural parents married and still living together. Sixty-five percent of the runaways at Contact Center reported that their parents were divorced or widowed. None were separated and there was no information available on two subjects. Fifty-six percent of the Juvenile Court runaways had parents who are now separated, or divorced, or who were unwed at 
the time of the child's birth.

The marital status of the control group's parents contrasted markedly with that of the runaways' parents. Only $24 \%$ of the nonrunaway subjects reported that their parents were separated or divorced. Thus, our preliminary data tends to counter the findings of a Utah study which claimed that problems which could precipitate and cause a youth to run away from home are just as likely to occur in a home with both parents present as they are in other living arrangements.

\begin{tabular}{lccc}
\hline $\begin{array}{c}\text { Parents } \\
\text { Marital Status }\end{array}$ & Contact & JOH & Control \\
\hline Married & 8 & 7 & 34 \\
Separated & 0 & 1 & 3 \\
Divorced & 12 & 7 & 8 \\
Widowed & 3 & 0 & 0 \\
Unmarried & 0 & 1 & 0 \\
Unanswered & 2 & 0 & 0 \\
Totals & 25 & 16 & 45 \\
\hline
\end{tabular}

\section{Legal Custody}

The correlation between a disrupted home situation and running away that was suggested in the question regarding parents' marital status was further supported by data concerning legal custody of youths. of the combined runaway sample $(N=39)$, approximately $35 \%$ of the youngsters were not in the custody of either one of their natural parents.

In contrast to the runaway sample, all but one member of the control group was in the custody of either one or both of their natural parents. It was decided to continue inquiry as to the legal custody 
of subjects in the second phase of the study because of the potential value of the data as an additional indicator of the nature of family structure and relations.

\begin{tabular}{lccc}
\hline $\begin{array}{c}\text { Legal Custody } \\
\text { Of Child }\end{array}$ & Contact & JDH & Control \\
\hline Parents & 15 & 10 & 44 \\
Court & 7 & 5 & 0 \\
Welfare & 1 & 0 & 0 \\
Relative & 0 & 0 & 1 \\
$\begin{array}{l}\text { Children's } \\
\text { Farm Home }\end{array}$ & 0 & 1 & 0 \\
$\begin{array}{l}\text { Unanswered } \\
\text { Total }\end{array}$ & 2 & $\underline{0}$ & $\underline{0}$ \\
\end{tabular}

Siblings and Position in Family

A11 subjects were questioned in regard to the number of brothers and sisters in their family as well as the total number of siblings presently living at home. This question was included on the assumption that stress leading to a youngster's decision to leave home might be associated with the total number of siblings in his family. It was reasoned that in large families a child would face more competition for attention and affection from his parents. The frustration resulting from such sibling rivalry could contribute to runaway behavior.

It was found that the total number of siblings was considerably larger in the families of runaway youth as compared to non-runaways. The average number of siblings for Contact Center runaways was 4.00 ; Juvenile Court runaways averaged 3.13 ; while the control 
group had a low of 2.80 siblings. It was hoped that an increased sample size for the second questionnaire would support and clarify the possible correlation between famfly size and runaway behavior.

\begin{tabular}{|c|c|c|c|}
\hline No. of Siblings & Contact & JDH & Control \\
\hline $\begin{array}{l}\# \text { Brothers } \\
0 \\
1 \\
2 \\
3 \\
4 \\
5 \\
\text { Unanswered } \\
\text { Total }\end{array}$ & $\begin{array}{r}3 \\
7 \\
6 \\
2 \\
3 \\
2 \\
2 \\
\frac{2}{25}\end{array}$ & $\begin{array}{c}3 \\
4 \\
2 \\
3 \\
3 \\
1 \\
0 \\
16\end{array}$ & $\begin{array}{r}4 \\
27 \\
8 \\
2 \\
2 \\
1 \\
\frac{1}{45}(2 \text { half bros.) }\end{array}$ \\
\hline $\begin{array}{l}\text { \# Sisters } \\
0 \\
1 \\
2 \\
3 \\
4 \\
5 \\
6 \\
\text { Unanswered } \\
\text { Total }\end{array}$ & $\begin{array}{c}3 \\
7 \\
7 \\
3 \\
1 \\
1 \\
1 \\
\frac{2}{25}\end{array}$ & $\begin{array}{l}6 \\
3 \\
3 \\
2 \\
0 \\
0 \\
0 \\
\frac{2}{16} \text { (half sister) }\end{array}$ & $\begin{array}{r}12 \\
16 \\
7 \\
9 \\
0 \\
1 \\
0 \\
0 \\
\frac{0}{45}\end{array}$ \\
\hline $\begin{array}{c}\text { Total \# Siblings } \\
0 \\
1 \\
2 \\
3 \\
4 \\
5 \\
6 \\
7 \\
8 \\
\text { Unanswered } \\
\text { Total }\end{array}$ & $\begin{array}{l}0 \\
2 \\
4 \\
4 \\
1 \\
6 \\
2 \\
1 \\
2 \\
3 \\
25\end{array}$ & $\begin{array}{l}1 \\
3 \\
5 \\
1 \\
1 \\
1 \\
2 \\
2 \\
0 \\
0 \\
\frac{0}{16}\end{array}$ & $\begin{array}{r}0 \\
13 \\
10 \\
7 \\
9 \\
3 \\
2 \\
0 \\
1 \\
0 \\
\frac{0}{45}\end{array}$ \\
\hline
\end{tabular}

Data on the subjects' approximate ordinal position in the family suggested that the youngest child might be less prone toward running away. 


\begin{tabular}{lccc}
\hline $\begin{array}{c}\text { Child's Position } \\
\text { In Family }\end{array}$ & Contact & JDH & Control \\
\hline 0ldest & 4 & 6 & 7 \\
Middle & 10 & 8 & 18 \\
Youngest & 9 & 1 & 20 \\
Unanswered & 2 & 1 (only & 0 \\
Total & - & - child) & - \\
\hline
\end{tabular}

Family on Welfare

Investigation of a possible correlation between the socioeconomic status of the parents and youth running away from home was attempted in a very general manner with the inquiry as to whether the family was receiving welfare or not. It was decided that this question would yield a gross indication of the family income and probably would be more reliable than the youth's own estimate of his family's income. However, it is possible that younger subjects might be unaware that their parent(s) were receiving public assistance or that some subjects would be reluctant to acknowledge this fact on a questionnaire.

\begin{tabular}{lccc}
\hline $\begin{array}{l}\text { Is The Family } \\
\text { On Welfare? }\end{array}$ & Contact & JDH & Control \\
\hline$\dot{\text { Yes }}$ & 6 & 4 & 1 \\
No & 15 & 12 & 44 \\
Unanswered & $\underline{4}$ & $\underline{0}$ & $\underline{0}$ \\
Total & 25 & 16 & 45 \\
\hline
\end{tabular}

The results of our relatively small first sample pointed to an 
association between low family income and a youngster leaving home. Twenty-nine

Forty percent of the Contact Center runaways were on public assistance ( $N=21$; no information on four subjects). One-third of the runaways referred to Juvenile Court were on welfare. Only one subject out of 45 in the control group reported that their family was receiving public assistance.

Previous Juvenile Court Referral

The vast majority of identified runaways for whom information was available stated that they had previously been referred to Juvenile Court. Sixteen out of 23 runaways at Contact Center reported that they had been to Juvenile Court before. (No information available on two subjects.) Ten of these 16 previous court clients had been referred because of runaway or runaway in combination with other offenses such as breaking and entering, drug use, shoplifting, and truancy. Thirteen of the sixteen runaway subjects from Juvenile Court also had prior court referrals. However, no information was gathered on the nature of the previous referral with the initial questionnaire. In contrast to the experimental sample no members of the control group reported previous court contacts.

\begin{tabular}{lccc}
\hline $\begin{array}{c}\text { Previous Juvenile } \\
\text { Court Referrals }\end{array}$ & Contact & JDH & Control \\
\hline Yes & 16 & 13 & 0 \\
No & 6 & 3 & 45 \\
Unanswered & $\underline{3}$ & $\underline{0}$ & $\underline{0}$ \\
Total & 25 & 16 & 45 \\
\hline
\end{tabular}




\begin{tabular}{lccc}
\hline $\begin{array}{c}\text { Previous Juvenile } \\
\text { Court Referrals }\end{array}$ & Contact & JDH & Control \\
\hline If yes, why? & & & \\
runaway & 4 & (not & (not \\
foster home & 1 & avail.) & applic.) \\
burglary & 1 & & \\
incorrigible & 1 & & \\
combination & 6 & & \\
unanswered & 3 & \\
Total & 16 & \\
\hline
\end{tabular}

At least for this limited sample of 29 runaways it would appear that court intervention had little effect in deterring subsequent anti-social behavior or in relieving the emotional, interpersonal, or situational stress from which the youngster fled.

\section{School Information}

Responses from the Contact Center runaway group were not complete enough to make a definite determination of whether most of these youngsters were regularly attending school or had dropped out before they left home. As the first schedule was administered during the summer, some of the responses to the school attendance question may have been confused because of summer vacation.

\begin{tabular}{lccc}
\hline \multicolumn{4}{c}{ Was Child Attending } \\
Contact & $\begin{array}{c}\text { School } \\
\text { JDH }\end{array}$ & $\begin{array}{c}\text { When He Ran Away? } \\
\text { Control }\end{array}$ \\
\hline Yes & 7 & 13 & (not applicable) \\
No & 6 & 3 & \\
Unanswered & $\underline{12}$ & $\underline{0}$ & \\
Total & 25 & 45 & \\
\hline
\end{tabular}


It is assumed that some of the subjects who failed to answer the question were in school, then approximately half of the combined experimental groups were still in school before they ran.

In an effort to explore a possible link between school problems and runaway behavior, all subjects were questioned as to whether they had ever been in any serious trouble at school over a third of the Contact Center runaways and about half of the youngsters referred to Juvenile Court reported that they had been "in trouble" at school.

\begin{tabular}{|c|c|c|c|}
\hline Has Child Been Ir & $\begin{array}{l}\text { Serious Tr } \\
\text { Contact }\end{array}$ & $\begin{array}{l}e \text { in } \\
J_{D H^{*}}\end{array}$ & $\begin{array}{l}\text { hool? } \\
\text { Control }\end{array}$ \\
\hline Yes & 8 & 7 & 7 \\
\hline No & 14 & 8 & 38 \\
\hline Unanswered & 3 & 1 & 0 \\
\hline Total & 25 & 16 & 45 \\
\hline \multicolumn{4}{|l|}{ If yes, what? } \\
\hline truancy & 3 & 5 & 0 \\
\hline smoking & 0 & 0 & 2 \\
\hline marihuana & 1 & 0 & 0 \\
\hline teacher conflict & 1 & 0 & 0 \\
\hline "bad attitude" & 0 & 2 & 0 \\
\hline fighting & 0 & 2 & 0 \\
\hline breaking rules & 0 & 1 & 2 \\
\hline combination & 2 & 0 & 0 \\
\hline unanswered & 1 & $\underline{0}$ & 3 \\
\hline Total & 8 & 10 & 7 \\
\hline
\end{tabular}


By comparison, only $15 \%$ of the non-runaway control group noted school trouble. In general, the type of behavior which got youngsters into trouble at school was of a more serious nature for runaways than for the non-runaway control group. Lincoln and Cleveland High students reported behavior such as skipping study halls, smoking cigarettes, and water fights. However, runaway subjects listed truancy, fighting, marthuana, assault, teacher conflict, etc. as causing difficulty at school. Truancy was the behavior most often noted as the reason for trouble at school.

An open-ended question directed at probing the general feelings of the subject toward his school experience was included in the first questionnaire. Interviewers (counselors) were instructed to solicit the nature of the attitudes as well as the degree of emotion accompanying the response. The answers that were obtained to this question encompassed such a variety of situation-specific or, alternately, extremely vague statements that categorization for the purposes of analysis was quite difficult. Interpretation of the question was attempted by assigning the responses to an approximate scaling system ranging from DISLIKE to LIKE.

The Contact Center runaways were proportionately the most dissatisfied with school; almost half of the subjects indicated a definite dislike for school. Juvenlle Court subjects demonstrated a somewhat more positive attitude toward school. Very few members of the high school control group had strong positive or negative feelings regarding school. Approximately $70 \%$ of the control responses fell into the middle ground of liking school with various 
qualifications, i.e., it was "necessary," "OK," or "airight except for certain aspects," etc.

\begin{tabular}{lccc}
\hline & How Child Feels & About School & \\
Contact & JDH & Control \\
\hline Like & 4 & 2 & 6 \\
Like w/qualifications & 2 & 2 & 13 \\
Okay & 5 & 7 & 9 \\
Necessary & 1 & 0 & 9 \\
Dislike & 11 & 4 & 8 \\
Unanswered & 2 & 1 & 0 \\
Total & 25 & 16 & 45 \\
\hline
\end{tabular}

Family Relations: Feelings and Perceptions

Included on the first schedule was a second series of open-ended questions that focused on the subject's feelings toward his parents and other family members as well as his perception of their feelings toward him. Because considerations of time and confidentiality prevented a more extensive analysis of family interpersonal relations, we felt that it was particularly important to begin probing this area al though, initially, in a very impressionistic manner.

The high school control group expressed proportionately the most positive attitudes toward their parents with almost half of the subjects stating explicitly that they "loved" or "liked" them. Another $20 \%$ of the control group expressed satisfactory but less enthusiastic attitudes, such as "they're OK." The Contact Center runaways, by and large, were more negative in their expression of feelings toward their parents. A further indication of family discord was the fact that responses from this group were often divided between parents, e.g., 
warm emotions directed toward the mother and open hostility or resentment toward the father.

In contrast to the sample from Contact Center, runaways at Juventle Court were markedly more positive in their feelings toward their parents. Almost $70 \%$ indicated that they "loved" or "liked" their parents. Several factors were considered as possible contributors to the difference between the two runaway groups on this question:

1. The JDH group of youngsters was more actively repressing negative feelings toward their parents and/or idealizing their relationship. It should be noted that several subjects were committed to institutions and, therefore, were separated from their families.

2. The authority of the Juvenile Court and its representative (the counselor-interviewer) inhibited the expression of less socially acceptable feelings toward one's parents or guardian, i.e., anger or hostility.

3. Other situational or personal problems were more significant for this group then dislike of parents in the decision to run away.

\begin{tabular}{|c|c|c|c|}
\hline How Chil & $\begin{array}{c}\text { Feels Toward } \\
\text { Contact }\end{array}$ & $\begin{array}{l}\text { Parents } \\
\text { JDH }\end{array}$ & Control \\
\hline Positive attitude & 6 & 11 & 21 \\
\hline $\begin{array}{l}\text { Attitude split } \\
\text { between parents } \\
\text {. }\end{array}$ & 7 & 0 & 3 \\
\hline Negative attitude & 9 & 1 & 7 \\
\hline $\begin{array}{l}\text { Varied attitude } \\
\text { toward parents }\end{array}$ & 2 & 2 & 3 \\
\hline Don't know & 1 & 0 & 2 \\
\hline Satisfactory & 0 & 0 & 9 \\
\hline Unanswered & $\underline{0}$ & 2 & 0 \\
\hline Total & $\overline{25}$ & $\overline{16}$ & $\overline{45}$ \\
\hline
\end{tabular}


Juvenile Court responses to the inquiry about parents' feelings toward the children tended to strengthen our speculation that these subjects may have been reluctant to acknowledge the extent of conflict between their parents and them. It may be that Juvenile Court runaways found it easier to express emotional conflict with parents by attributing negative feelings to their parents rather than to themselves. At any rate, the court group showed a definite increase in negative feelings (hositility, rejection, criticism) over the previous question.

\begin{tabular}{lccc}
\hline \multicolumn{3}{c}{ How Child Thinks His Parents } & Feel Toward Him \\
& Contact & JOH & Control \\
\hline Positive attitude & 6 & 6 & 22 \\
Negative attitude & 10 & 6 & 6 \\
$\begin{array}{l}\text { Parents have varied } \\
\text { attitude }\end{array}$ & 3 & 0 & 7 \\
$\begin{array}{l}\text { Parents are split } \\
\text { in attitude }\end{array}$ & 1 & 0 & 0 \\
$\begin{array}{l}\text { Satisfactory } \\
\begin{array}{l}\text { Don't know } \\
\text { Unanswered }\end{array}\end{array}$ & 0 & 0 & 9 \\
Total & 3 & 2 & 1 \\
\hline
\end{tabular}

Responses from the Contact Center and control group were, in general, consistent with answers to the previous question. Although highly tentative, this finding seemed to support an interpretation that running away is an indication of a lack of harmony and warmth in a youngster's relationship with his parents.

Answers to the pair of questions about the subject's feelings 
toward other family members and his perception of their feelings about him were fairly consistent with the preceding set of questions in that the non-runaways tended to express and identify more positive feelings between family members. The Juvenile Court group again had fewer subjects than Contact Center who expressed or perceived negative or mixed feelings in regard to other family members.

\begin{tabular}{|c|c|c|c|}
\hline Child's Feelings & $\begin{array}{c}\text { Toward 0ther } \\
\text { Contact } \\
\end{array}$ & $\begin{array}{c}\text { Family } \\
\text { JDH }\end{array}$ & $\begin{array}{c}\text { Members } \\
\text { Control }\end{array}$ \\
\hline Positive attitude & 9 & 9 & 24 \\
\hline Negative attitude & 4 & 1 & 3 \\
\hline Mixed feelings & 7 & 0 & 5 \\
\hline Satisfactory & 0 & 2 & 11 \\
\hline Jealous & 1 & 0 & 0 \\
\hline "Mothering" & 0 & 1 & 0 \\
\hline Don't know & 1 & 0 & 0 \\
\hline Unanswered & 3 & $\underline{3}$ & 2 \\
\hline Total & 25 & 16 & 45 \\
\hline
\end{tabular}

\begin{tabular}{lccc}
\hline How Child Thinks Family & Members & Feel Toward Him \\
& Contact & JDH & Control \\
\hline Positive attitude & 10 & 8 & 21 \\
Negative attitude & 4 & 5 & 7 \\
Neutral & 1 & 0 & 0 \\
Satisfactory & 0 & 1 & 9 \\
Mixed & 4 & 0 & 3 \\
Don't know & 1 & 0 & 5 \\
Unanswered & 5 & 2 & 0 \\
Total & $\frac{5}{25}$ & $\frac{2}{46}$ & $\frac{45}{2}$ \\
\hline
\end{tabular}


As with the attitudinal questions about school, the advantages of a scaled response over an open-ended response in soliciting information about family relations was clear from the preliminary study. It was hoped that with the assignment of numerical values to content areas that probed attitudes and feelings that significant correlations and differences would be more readily identifiable.

\section{Decision-Making Process}

The Juvenile Court and control groups were questioned as to who made the major decisions in matters important to the youngster. Most of the subjects felt that the decision-making power was in their parents' hands. But nearly half of the control group as compared to $25 \%$ of the JDH subjects claimed that issues were decided on a democratic basis in their home. The extent to which the authority and responsibility of decision-making is shared within a family may be another index of whether certain families are more likely to encounter runaway behavior in their children.

\begin{tabular}{llcc}
\hline & Who Makes Major Decisions & \multicolumn{3}{c}{ Re: Child? } \\
& Contact & jDH & Control \\
\hline Parents & (wasn't on & 7 & 23 \\
Child & question- & 4 & 1 \\
Democratic basis & naire) & 4 & 20 \\
Unaniswered & & 1 & 1 \\
Total & & 16 & 45 \\
\hline
\end{tabular}

The staff at Runaway House in Washington, D.C. reported that the "reasons" kids give for running away are usually that their parents didn't like their hair, their clothes, or their friends, 
and they just got "tired of hassling it."49 In view of this observation, all subjects on our study were asked to indicate if these areas and others were a source of conflict in their family and, if so, who usually decided the issue. Answers to this inquiry were difficult to interpret on the questionnaire and/or were incomplete. However, available data suggested some trends in the areas of child conflict and decision-making.

Youngsters in the control group felt that they were generally able to decide questions about their clothes, friends, hair, smoking, and school. Parents of control subjects tended to make the decisions about where their child could go and the hours he kept. The parents of Contact Center runaways had most decision-making power about the hours their child kept, his friends, where he could go, and drugs. Areas of greatest conflict for Juvenile Court subjects seemed to be where they went, their friends, hours, and drugs. Although no accurate tabulation could be made about decision-making authority in these conflict areas for the Juvenile Court sample, it was noted that four of the subjects claimed to be making their own decisions on all issues.

On the basis of the limited data, we could speculate that the amount of decision-making responsibility given to the child influences their adjustment in the family. Since the control group tended to make most of the decisions, and the runaways had either conflict or their parents deciding issues, perhaps a child who is able to exercise his own judgment about matters which concern him is less susceptible 
to running away.

Significant Other Adults

All subjects were asked what adults (they) would talk to about important things in order to determine if the existence of a person in whom they could trust and confide would mitigate against the impulse to run away from home. Approximately $40 \%$ of the control group identified one or both of their parents as the person(s) with whom they discuss important matters. Only 3 out of 44 control subjects stated that they had no one to talk with seriously. Seven of 14 (two did not answer) members of the Juventle Court group listed one or more adults. But a surprising one-third of the Contact Center runaways indicated that they had no one with whom to discuss things that were important to them.

\begin{tabular}{|c|c|c|c|}
\hline \multirow{2}{*}{\multicolumn{4}{|c|}{ What AduTts Does Child Have To Talk lo }} \\
\hline & & & \\
\hline Parents & 4 & 3 & 17 \\
\hline Friends & 3 & 4 & 6 \\
\hline Relative & 4 & 2 & 2 \\
\hline Professionals & 2 & 1 & 3 \\
\hline Combination & 1 & 2 & 13 \\
\hline None & 7 & 0 & 3 \\
\hline Anyone but parents & 0 & 1 & 0 \\
\hline Don't know & 0 & 1 & 0 \\
\hline Unanswered & 4 & 2 & 1 \\
\hline Total & 25 & 16 & 45 \\
\hline
\end{tabular}

Friendships

The majority of subjects in both the experimental and control 
groups stated that they had at least one close friend. However, a much higher proportion of the non-runaway group answered this question affirmatively. Nearly half of the Juvenile Court runaways had no close friendships.

The combined data from the questions concerning parents, other family members, and adult and peer friendships lends itself to a picture of runaway youth as having more difficulty with close interpersonal relationships than non-runaway adolescents. It appears that a runaway's family relationships may be more turbulent and that friendships with adults and peers outside the family are likely to be fewer as compared with non-runaways.

\begin{tabular}{|c|c|c|c|}
\hline Does Child Have & $\begin{array}{l}\text { Any Close } \\
\text { Contact }\end{array}$ & $\begin{array}{c}\text { Friendship } \\
\text { JDH } \\
\end{array}$ & $\begin{array}{l}\text { s? } \\
\text { Control }\end{array}$ \\
\hline Yes & 21 & 11 & 42 \\
\hline No & 3 & 5 & 3 \\
\hline Unanswered & 1 & $\underline{0}$ & $\underline{0}$ \\
\hline Total & 25 & 16 & 45 \\
\hline \multicolumn{4}{|l|}{ If yes, how many? } \\
\hline 1 & 7 & 4 & 3 \\
\hline 2 & 7 & 1 & 8 \\
\hline 3 & 1 & 3 & 10 \\
\hline many & 6 & 3 & 19 \\
\hline undetermined & 0 & 0 & 1 \\
\hline unanswered & $\underline{0}$ & $\underline{0}$ & 1 \\
\hline Total & 21 & 11 & 42 \\
\hline
\end{tabular}




\section{The Runaway Experience}

The preliminary study also included a series of questions regarding the runaway incident that brought the youth to one of the two agencies and his opinions about some aspects of the experience. It should be noted that $70 \%$ of the high school control group had previously considered leaving home. The most frequent reason listed for abandoning the plan to leave was that they had given this option more careful thought and decided that it wouldn't resolve the problem for them.

\begin{tabular}{|c|c|c|c|}
\hline If Child Has Never Rur & $\begin{array}{l}\text { Away, Has } \\
\text { Contact }\end{array}$ & $\begin{array}{c}\text { He Consi } \\
\text { JDH }\end{array}$ & $\begin{array}{l}\text { ered It? } \\
\text { Control } \\
\end{array}$ \\
\hline Yes & not & not & 31 \\
\hline No & applic. & applic. & 13 \\
\hline Unanswered & & & 1 \\
\hline Total & & & 45 \\
\hline \multicolumn{4}{|l|}{$\begin{array}{l}\text { If yes, why'd you } \\
\text { change your mind? }\end{array}$} \\
\hline thought it out & & & 11 \\
\hline fear of unknown & & & 7 \\
\hline worry/hurt parents & & & 6 \\
\hline punishment & & & 5 \\
\hline nowhere to go & & & 2 \\
\hline total & & & 31 \\
\hline
\end{tabular}

Almost all of the experimental group had left home before, and over half of each group had run away at least twice before. This data would indicate that once a youngster has tried running away as a method of coping with his problems, he is likely to repeatedly 
leave home.

\begin{tabular}{|c|c|c|c|}
\hline \multicolumn{3}{|c|}{ Has Child Run Away Before? } & \multirow{3}{*}{$\begin{array}{l}\text { Control } \\
\text { Not } \\
\text { Applic. }\end{array}$} \\
\hline Yes & 22 & 13 & \\
\hline No. & 2 & 3 & \\
\hline Unanswered & 1 & $\underline{0}$ & \\
\hline Tota 1 & 25 & 16 & \\
\hline \multicolumn{4}{|c|}{ How many times? } \\
\hline once & 7 & 3 & \\
\hline twice & 5 & 5 & \\
\hline 3 & 1 & 1 & \\
\hline 4 & 2 & 1 & \\
\hline many & 6 & 2 & \\
\hline unanswered & 1 & 1 & \\
\hline total & 22 & 13 & \\
\hline
\end{tabular}

Although $75 \%$ of the runaways in this study were 15 years of age or younger, most of these youth left home alone rather than with companions. Eighty-six percent of the Contact Center runaways and $62 \%$ of the court sample were away from home less than four weeks. A majority of both runaway groups had no specific destination in mind when they left home.

\begin{tabular}{|c|c|c|c|}
\hline & $\begin{array}{r}\text { Away Alone } \\
\text { Contact } \\
\end{array}$ & $\begin{array}{c}\text { or W/0th } \\
\text { JDH }\end{array}$ & Control \\
\hline Alone & 17 & 10 & \multirow{2}{*}{$\begin{array}{c}\text { Not } \\
\text { Applic. }\end{array}$} \\
\hline Others & 8 & 6 & \\
\hline Total & 25 & 16 & \\
\hline
\end{tabular}




\begin{tabular}{|c|c|c|c|}
\hline How Long Was Chi & $\begin{array}{r}\text { Away From } \\
\text { Contact }\end{array}$ & $\begin{array}{r}\text { Home } 0 r \\
\text { JDH }\end{array}$ & $\begin{array}{c}\text { Guardian? } \\
\text { Control }\end{array}$ \\
\hline Less than week & 11 & 5 & \multirow{7}{*}{$\begin{array}{l}\text { Not } \\
\text { Applic. }\end{array}$} \\
\hline Less than 4 weeks & 8 & 5 & \\
\hline 1 to 6 months & 1 & 6 & \\
\hline 6 to 12 months & 1 & 0 & \\
\hline Over a year & 1 & 0 & \\
\hline Unanswered & 6 & $\underline{0}$ & \\
\hline Total & 28 & 16 & \\
\hline
\end{tabular}

\begin{tabular}{|c|c|c|c|}
\hline Where Was & $\begin{array}{c}\text { Child Going When } \\
\text { Contact }\end{array}$ & $\begin{array}{l}\mathrm{He} \operatorname{Ran} ? \\
\mathrm{JDH}\end{array}$ & Control \\
\hline Relative's & 3 & 1 & \multirow[t]{10}{*}{$\begin{array}{l}\text { Not } \\
\text { Applic. }\end{array}$} \\
\hline Portland & 3 & 0 & \\
\hline Friends' & 2 & 4 & \\
\hline Contact & 2 & 0 & \\
\hline $\begin{array}{l}\text { Home (from } \\
\text { Institution) }\end{array}$ & 1 & 0 & \\
\hline Find Sister & 0 & 1 & \\
\hline Rock Festival & 0 & 1 & \\
\hline Didn't know & 13 & 9 & \\
\hline Unanśwered & 1 & $\underline{0}$ & \\
\hline Total & 25 & 16 & \\
\hline
\end{tabular}

A fight or argument with their parents was the precipitating incident most often identified by runaway youth of both groups. Such responses are consistent with data showing "freedom" as the aspect of running away that was most frequently liked by both groups. However, 
five Contact Center subjects stated that they 1iked "nothing" about running away.

\begin{tabular}{lccc}
\hline \multicolumn{3}{c}{ What Happened Just } & \multicolumn{3}{c}{ Before Child Ran } \\
Contact & JDH & Control \\
\hline Fight w/parents & 12 & 6 & $\begin{array}{c}\text { Not } \\
\text { Applic. }\end{array}$ \\
Fight w/siblings & 1 & 0 & \\
Severe restrictions & 2 & 0 & \\
"Fed Up" & 3 & 0 & \\
Ran from institution & 1 & 2 \\
Disappt. w/parents & 1 & 0 \\
Impulse & 0 & 2 \\
Seeking people & 0 & 1 \\
Other & 2 & 5 \\
Unanswered & 3 & 0 \\
Totals & 25 & 16 \\
\hline
\end{tabular}

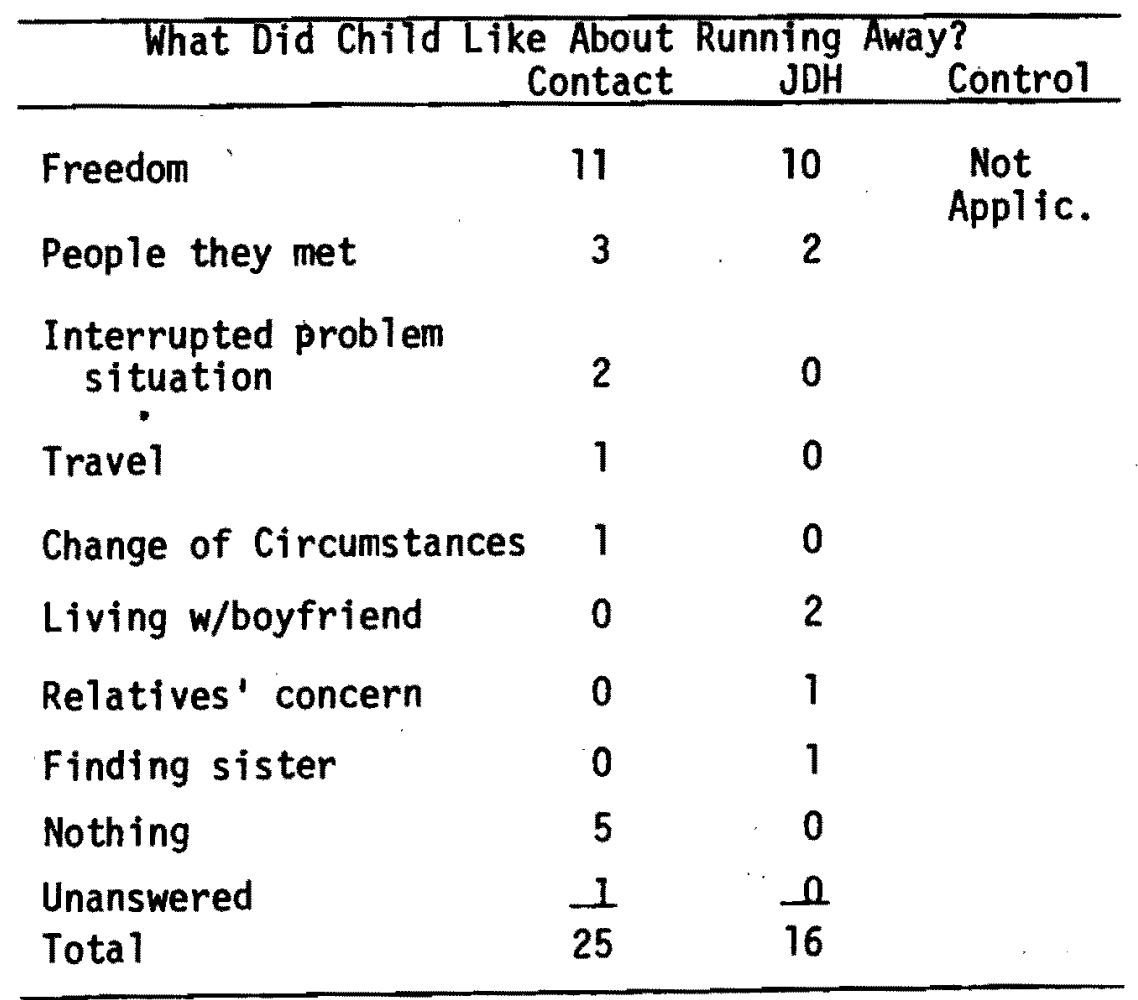


Sixty-one percent of the Contact Center sample stated that paranoia, fear and legal hassles were the things that they did not like about running away. None of these problems were singled out by the Juvenile Court group. By comparison, 75\% of the Juvenile Court sample identified basic survival, loneliness, and getting caught as the aspects of running away they did not like.

\begin{tabular}{|c|c|c|c|}
\hline What Did The Child & $\begin{array}{l}\text { Not Like Al } \\
\text { Contact } \\
\end{array}$ & $\begin{array}{l}\text { Runr } \\
\text { JDH }\end{array}$ & $\begin{array}{l}9 \text { Away? } \\
\text { Control }\end{array}$ \\
\hline Paranoia/fear & 8 & 0 & \multirow{9}{*}{$\begin{array}{l}\text { Not } \\
\text { Applic. }\end{array}$} \\
\hline Legal hassle & 6 & 0 & \\
\hline Survival/loneliness & 4 & 6 & \\
\hline Everything & 2 & 0 & \\
\hline Nothing & 1 & 3 & \\
\hline Getting caught & 0 & 6 & \\
\hline Other & 2 & 1 & \\
\hline Unanswered & 2 & $\underline{0}$ & \\
\hline Total & 25 & 16 & \\
\hline
\end{tabular}

When asked specifically how they felt about returning home, 25\% of the Contact Center runaways as compared to $62 \%$ of the Juvenile Court sample wanted to return home at the time they were completing the questionnaire. Seventy-one percent of the group at Contact Center, as opposed to $38 \%$ of the Juvenile Court runaways, did not want to return home at that time. (There was no "home" available as an option for one subject in each group.)

When asked what kind of help they wanted from the agency, onethird of the runaways at Contact Center said that they would like 
counseling services.

\begin{tabular}{lccc}
\hline $\begin{array}{l}\text { How Child Felt About } \\
\text { naire. }\end{array}$ & $\begin{array}{c}\text { Going Home } \\
\text { Contact }\end{array}$ & $\begin{array}{c}\text { When Doing } \\
\text { JDHestion- }\end{array}$ & $\begin{array}{c}\text { Questrol } \\
\text { Cont }\end{array}$ \\
\hline Want to & 6 & 8 & $\begin{array}{c}\text { Not } \\
\text { Applic. }\end{array}$ \\
Don't want to & 17 & 5 & \\
No "home" available & 1 & 1 & \\
Unsure & 1 & 0 & \\
Unanswered & $\underline{0}$ & 2 & 16 \\
Total & 25 & 16 & \\
\hline
\end{tabular}

Almost half of the subjects wanted assistance in finding a foster home or other housing arrangement. None of the Contact Center runaways specifically requested help in returning to the home situation that they had left.

\begin{tabular}{lccc}
\hline What Kind of Help Did Child Want & $\begin{array}{c}\text { From Agency? } \\
\text { Contact }\end{array}$ & $\begin{array}{c}\text { JDH } \\
\text { Control }\end{array}$ \\
\hline Counseling & 8 & 1 & $\begin{array}{c}\text { Not } \\
\text { Applic. }\end{array}$ \\
Foster Home & 6 & 4 & \\
Housing & 5 & 0 & \\
Information & 1 & 0 & \\
None & 2 & 3 & \\
Out of institution & 1 & 0 \\
To go home & 0 & 4 \\
Emancipation & 0 & 1 \\
Protect from running & 0 & 1 \\
Doesn't know & 1 & 2 \\
Combination & 1 & 0 \\
Total & 25 & 16 \\
\hline
\end{tabular}


On the other hand, only one Juvenile Court runaway specifically stated that he wanted counseling. Twenty-eight percent of this group want a foster home placement and an equal number of youngsters wanted help in returning to their homes. Over $20 \%$ of this runaway sample did not want any help from the court. The sizeable portion of runaways who expressed "resistance" to receiving social services from Juvenile Court is probably indicative of the barriers to effective intervention that a non-voluntary agency with an authoritarian image must overcome.

An additional series of -five questions was included in the schedule administered to the Contact Center sample in order to obtain information that was of particular interest to the agency staff. Non-traditional youth-serving agencies, such as Contact Center have occasionally been a focus of criticism actually contributing to the runaway problem by providing services to runaway youngsters. Our finding that $72 \%$ of the runaways did not know about Contact Center before they left home would tend to counter the argument that youngsters leave home because they know they can receive assistance from certain agencies.

Our data showed that 17 out of 24 subjects first heard about Contact Center from their friends. Seventy-two percent of the youngsters stated their reasons for coming to Contact Center in very general terms, i.e., "to get help." Sixty percent of the group did not have any immediate plans, wished to return home (or to foster home), or simply wanted to "work out their problems." The remaining $40 \%$ of the sample wanted a different living situation (usually 
foster care) or wished to travel.

In regard to future plans, approximately half of the Contact Center runaways intended to continue with school or to find employment. The remaining subjects were unsure of long-range objectives or else responded with a variety of highly individualized plans for the future.

Disposition

Information on the actual or expected disposition of each case was solicited from the counselor-interviewer at both of the agencies.

\begin{tabular}{|c|c|c|c|}
\hline Disposition Fo & $\begin{array}{l}\text { Towing } \mathrm{Ag} \\
\text { Contact }\end{array}$ & $\begin{array}{l}\text { Ey Con } \\
\text { Court }\end{array}$ & ${ }^{t}$ Control \\
\hline Returned home & 5 & 6 & \multirow[t]{7}{*}{$\begin{array}{l}\text { Not } \\
\text { Applic. }\end{array}$} \\
\hline Foster care & 8 & 1 & \\
\hline $\begin{array}{l}\text { Placed in or returned } \\
\text { to institution }\end{array}$ & 3 & 6 & \\
\hline Lived on their own & 1 & 1 & \\
\hline $\begin{array}{l}\text { Remained "on the } \\
\text { street" }\end{array}$ & 8 & 0 & \\
\hline Unanswered & $\underline{0}$ & 2 & \\
\hline Total & 25 & 16 & \\
\hline
\end{tabular}

At the time the questionnaire was administered, Contact Center staff anticipated that a substantial $36 \%$ of their runaways would remain "on the street" or otherwise manage to live on their own. Nearly $50 \%$ of the runaways were returned to their own homes or placed in foster care. Only $12 \%$ of the runaways from Contact were committed to or returned to an institution. Within the Juvenile Court sample an equal percentage of the subjects (38 percent) were returned to their 
own homes or placed in or returned to institutions. The remaining subjects either lived on their own, went into foster care, or had not formulated a plan at the time the questionnaire was administered. Summary

As a result of the findings of the preliminary survey, certain content areas were revised, eliminated, or expanded in more detail on the final questionnaire. Questions relating to the demographic characteristics of the subjects were altered in three areas. The sibling question was enlarged so as to allow for more possibilities than simply "sisters" and "brothers." The section on living arrangement of the child before running away was made more explicit. Finally, the question concerning the child's legal custody was made specific to those subjects who were not living with either natural parent. Information on the frequency of visits with the absent parent was also added to the final questionnaire.

All open-ended "feeling" or attitudinal questions were transferred to a ten-point continuum scale so that appropriate data for statistical testing could be derived. Due to the shift in sampling procedures at Juvenile Court, i.e., interviews were conducted by the intake unit rather than the field counseling staff, information on case disposition was not available on the second questionnaire. The final schedule for Contact Center was shortened considerably by the deletion of several questions that pertained to only their clients' knowledge and use of the agency's services.

The results of preliminary questions relating to parents' marital status, total number of siblings in the family, previous runaway experience and Juvenile Court referrals, trouble in school, dislike of 
school, and relationships with parents and other adults seemed to be statistically different between runaways and non-runaways. These areas hold the most promise for statistical significance with a larger experimental sample in the final survey. 
CHAPTER FIVE

PRESENTATION AND INTERPRETATION OF DATA

FINAL SURVEY

INTRODUCTION

Evaluation of data collected on the final survey was accomplished by subjecting fourteen independent variables to Chi-square analysis. This testing determined if frequency distributions were compatible with theoretically expected ratios due to chance alone. In the case of five continuous variables offering interval data, analysis of variance was completed to examine whether the population means differed significantly from each other. A $5 \%$ level of significance was accepted for all statistical tests conducted.

It was necessary to subgroup many of the independent variables to insure cells of sufficient numerical magnitude for Chi-square analysis. In addition, two runaway subgroups (chronic and nonchronic runaways) were included in the testing and analysis of selected variables. The tables presented in this segment of the study represent the subgroups utilized for purposes of statistical testing. A more definitive compendium containing actual frequencies and prior to subgrouping is furnished in the Appendix. $\underline{\text { Sex }}$

There were substantially more females than males in the runaway sample, 61 percent as compared to 39 percent. This sex distribution could be explained by (1) a bias in the sample reflecting a distortion resulting from the fact that the study was completed in a limited 
period; or, more likely, (2) an upward trend in the frequency of females running away. As noted in the discussion of the preliminary study, the increase in the total number of runaway referrals to Juvenile Court in 1971 over 1970 was due to an increase in female referrals and a decrease in male runaway referrals during the same time period. Therefore, our data from both Contact Center and Juvenile Court as well as the statistics on total runaway referrals to Juvenile Court would indicate that females are more likely to be involved in runaway behavior.

\section{TABLE II}

Frequency and Distribution of Sex

\begin{tabular}{lrrrrrrrrrrr}
\hline & \multicolumn{2}{c}{ Contact } & \multicolumn{2}{c}{ Court } & \multicolumn{2}{c}{ Control } & \multicolumn{2}{c}{ Non-chronic } & \multicolumn{3}{c}{ Chronic } \\
SEX & No. & $\%$ & No. & $\%$ & No. & $\%$ & No. & $\%$ & No. & $\%$ \\
\hline Male & 6 & 26 & 22 & 44 & 22 & 66 & 14 & 40 & 14 & 38 \\
Female & 15 & 74 & 28 & 56 & 12 & 34 & 21 & 60 & 22 & 62 \\
& & & & & & & & & & \\
Total & 21 & 100 & 50 & 100 & 34 & 100 & 35 & 100 & 36 & 100 \\
\hline
\end{tabular}

Based on the 1971 Juvenile Court statistics for total runaway referrals, the sex distribution of our combined runaway group was judged to be an approximate representative sampling of runaways identified in. Multnomah County. 50

Separation of the total runaway group into chronic and non-chronic runaways for selected testing resulted in two nearly identical groups in terms of sex distribution. In contrast to the preliminary study, the non-runaway control group was predominantly male. Thus, the possibility'was introduced that the final survey's failure to substantiate 
preliminary trends may be due to the high male representation in the high school group.

Race

As in the preliminary study, both the control and experimental groups were predominantly Caucasian. Insufficient representation in racial minority categories precluded the use of Chi-square analys is.

TABLE III

Frequency and Percentage Distribution of Race

\begin{tabular}{|c|c|c|c|c|c|c|c|c|}
\hline \multirow[b]{2}{*}{ RACE } & \multicolumn{2}{|c|}{ Contact } & \multicolumn{2}{|c|}{ Court } & \multicolumn{2}{|c|}{ Control } & \multirow{2}{*}{$\begin{array}{l}\text { Non-chronic } \\
\text { No. } \%\end{array}$} & Chronic \\
\hline & No. & $\%$ & No. & $\%$ & No. & $\%$ & & No. $\%$ \\
\hline Black & 0 & 0 & 3 & 6 & 0 & 0 & NO COMPAR & SONS \\
\hline Indian & 0 & 0 & 2 & 4 & 0 & 0 & & \\
\hline $\begin{array}{l}\text { Cauca- } \\
\text { sian }\end{array}$ & 19 & 90 & 38 & 76 & 31 & 91 & & \\
\hline $\begin{array}{l}\text { Orien- } \\
\text { tal }\end{array}$ & 0 & 0 & 1 & 2 & 3 & 9 & & \\
\hline Mixed & 0 & 0 & 2 & 4 & 0 & 0 & & \\
\hline $\begin{array}{c}\text { Other } \\
\text { N.A. }\end{array}$ & 2 & 10 & 4 & 8 & 0 & 0 & & \\
\hline Total & 21 & 100 & 50 & 100 & 34 & 100 & & \\
\hline
\end{tabular}

The ethnic grouping of Portland Public School enrollment for 197071 was $87.1 \%$ Caucasian; $9.8 \%$ Black; 1.5\% Orienta 1; 1.0\% Spanish-American; $0 . \dot{6} \%$ American Indian. 51 Effort was made to select high schools for the control sample which were known to have a mixture of ethnic groups enrolled. In spite of this, our almost exclusively Caucasian control sample clearly is not representative of the expected ethnic distribution in the public schools.

Examination of frequency distributions would indicate that the 
runaway program at Contact Center is not being utilized by minority youth. The apparent lack of knowledge about and motivation to use the services of Contact Center on the part of non-white runaways may be influenced by a tendency of law enforcement agencies to identify and refer to Juvenile Court runaways with "higher visibility." Also, the southwest Portland, core-area location of Contact Center does not lend itself to easy accessibility for many east-side minority youth.

Age

Previous investigations of the runaway phenomenon have identified various "peak" or "high risk" ages for runaway behavior. Hildebrand's study in 1963 reported that the rate for girls increased with age and was highest at age 17 ; boys peaked at age 14 and 15 , and then declined sharply. ${ }^{52}$ Research conducted in Salt Lake County, Utah found that females peaked at age 14, decreased at age 15, and increased at ages 16 and 17 . The male runaways in this study peaked at age 16 and then declined rapidly. 53 Comparison of the peak runaway ages for the combined experimental sampling of males and females in this study differed from the findings of the research cited above, but was generally more consistent with the results of the Utah project in 1969. The female runaways peaked at age 15 and then declined sharply. On the other hand, male runaways peaked at age 14 , declined slightly at age 15, and reached the highest incidence at age 16. Over half of the total sample of runaways were 15 years of age or younger. This finding supports a conclusion that runaways are "shockingly young" as reported in 1967 by a national magazine. 54 (See Figure IV.) 


\section{FIGURE IV}

Age Grouping of Male and Female Runaways

in Final Survey

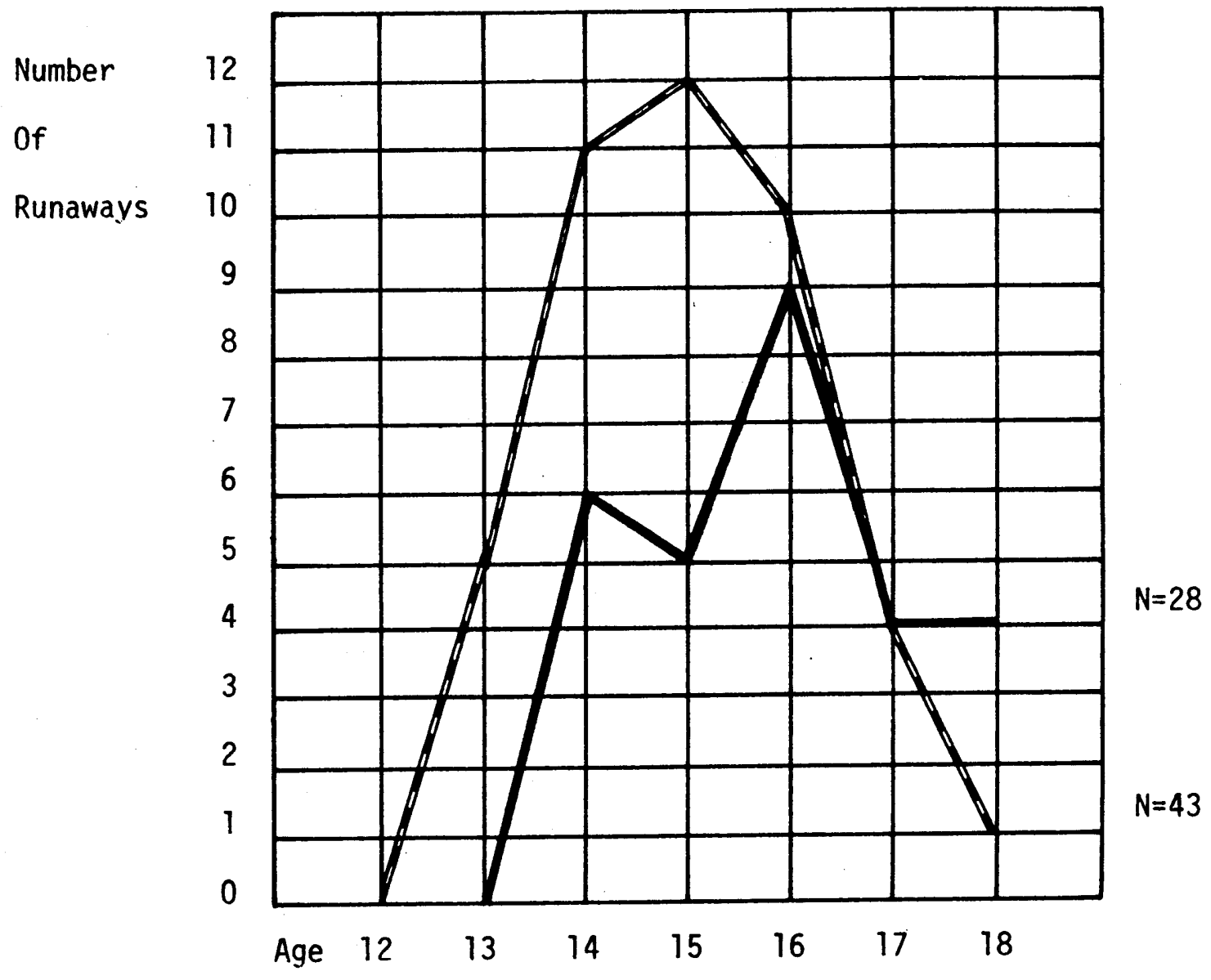

Fems re

Male 
TABLE IV

Frequency and Means of Subjects' Ages

\begin{tabular}{|c|c|c|c|c|c|c|c|c|c|c|}
\hline \multirow[b]{2}{*}{ AGE } & \multicolumn{2}{|c|}{ Contact } & \multicolumn{2}{|c|}{ Court } & \multicolumn{2}{|c|}{ Control } & \multicolumn{2}{|c|}{ Non-chrontc } & \multirow{2}{*}{\multicolumn{2}{|c|}{ Chronic }} \\
\hline & No. & $\%$ & No. & $\%$ & No. & $\%$ & No. & $\%$ & & \\
\hline $12-13$ & 1 & 5 & 4 & 8 & 0 & 0 & 1 & 3 & 4 & 11 \\
\hline $14-16$ & 16 & 76 & 37 & 74 & 33 & 98 & 27 & 77 & 26 & 72 \\
\hline $17-18$ & 4 & 19 & 9 & 18 & 1 & 2 & 7 & 20 & 6 & 17 \\
\hline Total & 21 & 100 & 50 & 100 & 34 & 100 & 35 & 100 & 36 & 100 \\
\hline Means & & & & & & & & & & \\
\hline$n=105$ & & .05 & & & & & & & & \\
\hline
\end{tabular}

The mean age of all runaways in this study was 15.3 years. Female runaways had the lowest average age (15.0 years) while male runaways tended to be older ( 15.8 years). A sampling procedure for the control group ( 1 imited to 9 th and 10 th grade classes) resulted in a lower mean age of 14.8 years for non-runaways. Contrary to what one might expect, a t-test of the chronic and non-chronic groups showed that the chronic runaways are significantly younger than their less experienced counterparts. Perhaps this is because kids are running away at earlier ages and in more frequency than other youth in previous times. The computed Chi-square value for the Contact, Juvenile Court, and Control groups was not sufficient to establish a statistically significant difference between the age: of the three populations. 
School Grade Level

Data on school grade level found $52 \%$ of the runaways from Contact Center and Juventle Court in the 9th and 10th grades, more than any other grade level. This frequency distribution corresponds to the expected level of school attainment for a predominantly 14-15 year old sample group. At this age in school, a young person is usually entering a larger, more sophisticated school setting (high school) that provides greater opportunity for social independence. Certainly much peer pressure is exhibited during this age for the adolescent to try new behaviors such as dating and learning to drive a car. We have speculated that the change in educational and social milieu may intensify the normal struggles of adolescents to establish their identity and autonomy, and thus lead to more serious conflicts with parents that of ten result in running away.

\section{TABLE $V$}

Frequency and Distribution of School Grade Levels

\begin{tabular}{|c|c|c|c|c|c|c|c|c|}
\hline GRADE & $\mathrm{Col}$ & $\overline{\mathrm{act}}$ & & & $\overline{\mathrm{COI}}$ & & Non-chronic & Chronic \\
\hline LEVEL & No. & $\%$ & No. & $\%$ & No. & $\%$ & No. & No. \\
\hline 7th-8th & 5 & 24 & 13 & 26 & 0 & 0 & NO COMPAR & SONS \\
\hline 9 th-10th & 7 & 33 & 27 & 54 & 33 & 97 & & \\
\hline 11 th-12th & 5. & 24 & 9 & 18 & 1 & 3 & & \\
\hline No answer & 4 & 19 & 1 & 2 & 0 & 0 & & \\
\hline Total & 21 & 100 & 50 & 100 & 34 & 100 & & \\
\hline
\end{tabular}

\section{Area of Residency}

As noted in the discussion of research methodology, our sampling 
procedure for the second phase of the study drew from the general population of runaways referred to the intake unit of Multnomah County Juvenile Court from January to February 1972. This runaway population differs from that obtained from field counselors in the preliminary survey in that it is not limited to Multnomah County residents. The difference in the sample populations of the two surveys is reflected in the fact that $40 \%$ of the subjects who completed the second questionnaire were not from the Tri-County area. We have no evidence to indicate that the inclusion of out-of-county residents biased the research findings.

\section{TABLE VI}

Frequency and Percentage Distribution of Residency Area

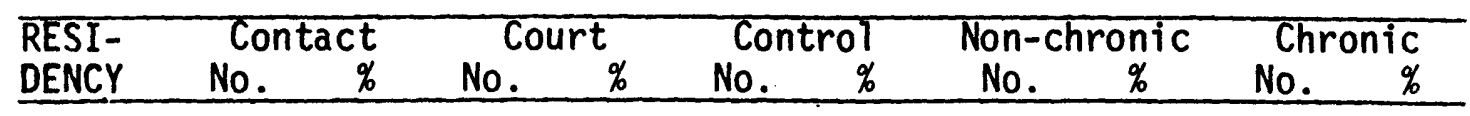

Portland

$\begin{array}{llllllll}\text { area } & 18 & 85 & 30 & 60 & 34 & 100 & \text { NO COMPARISONS }\end{array}$

Oregon

(not

$\begin{array}{llllll}\text { Portland) } 2 & 10 & 7 & 14 & 0 & 0\end{array}$

Out of

$\begin{array}{lllllll}\text { State } & 1 & 5 & 13 & 26 & 0 & 0\end{array}$

Total $\quad 21 \quad 100 \quad 50 \quad 100 \quad 34 \quad 100$

Our sample from Contact Center suggests that youth seeking runaway counseling from this agency are nearly all Portland area residents. It is probably the case that out-of-county runaways are more likely to request emergency assistance with food, housing or transportation rather than intensive counseling services. 
Welfare

The question regarding whether or not the subject's family was receiving public assistance was inadvertently omitted from the questionnaires administered to the Juvenile Court and control samples. Data from Contact Center showed that only one subject out of 18 reported that his family was on welfare. (Three subjects did not answer the question.) Due to the fact that data was incomplete, no conclusions were reached in regard to a possible correlation between runaway behavior and approximate family income.

\section{Marital Status of Natural Parents}

Subgrouping of parents who were married with parents who were separated (although, not necessarily legally separated) was compared with all other possible marital outcomes. The value yielded from Chisquare testing of the Court, Contact Center, and control group was not sufficient to establish a dependent relationship between marital status of natural parents and their children's runaway behavior. However, the control group did have the highest percentage of parents married or separated (62\%) when compared to Contact Center (57\%) and Juvenile Court (46\%).

Chi-square analysis of chronic and non-chronic runaways did result in a'statistically significant relationship between parents' marital status and recurrent runaway behavior, with $73 \%$ of the chronic runaways having natural parents not married or separated.

Statistical testing was also performed on married parents versus all other categories for Contact Center and Juvenile Court samples. Although the Chi-square value was not sufficient to establish a distinction between these two groups, the data suggested that the natural 
parents of Contact Center runaways were more likely to be still married than the parents of Juvenile Court subjects. Nearly $60 \%$ of the parents of Contact Center runaways were still married as compared to approximately $40 \%$ of the parents of Juvenile Court runaways.

TABLE VII

Frequency and Percentage Distribution of Marital Status of Natural Parents

\begin{tabular}{|c|c|c|c|c|c|c|c|c|c|c|}
\hline \multirow{2}{*}{$\begin{array}{l}\text { MARITAL } \\
\text { STATUS }\end{array}$} & \multicolumn{2}{|c|}{ Contact } & \multicolumn{2}{|c|}{ Court } & \multicolumn{2}{|c|}{ Control } & \multicolumn{2}{|c|}{ Non-Chronic } & \multicolumn{2}{|c|}{ Chronic } \\
\hline & No & $\%$ & No. & $\%$ & № & $\%$ & No. & $\%$ & No. & $\%$ \\
\hline $\begin{array}{l}\text { Married } \\
\text { Separa- } \\
\text { ted }\end{array}$ & 12 & 57 & 23 & 46 & 22 & 62 & 19 & 54 & 16 & 27 \\
\hline $\begin{array}{l}\text { Divorce } \\
\text { Widowed } \\
\text { Never } \\
\text { Marrie } \\
\text { Don't }\end{array}$ & & & & & & & & & & \\
\hline Know & 9 & 43 & 27 & 54 & 12 & 38 & 16 & 46 & 26 & 73 \\
\hline Total & 21 & 100 & 50 & 100 & 34 & 100 & 35 & 100 & 36 & 100 \\
\hline$n=106$ & & .05 & & .94 & & & & 5.46 & $\begin{array}{l}\text { p<. } \\
\text { d.f }\end{array}$ & \\
\hline
\end{tabular}

Chi square testing of the combined runaway populations versus the control group in terms of married parents as distinguished from all other possibilities did not result in a statistically significant relationship between runaway behavior and parents' marital status. Data from the final survey did not conclusively support the findings of the preliminary survey which suggested a defintte correlation between parents' marital status and running away. Percentage comparisons of all runaways versus the control group does suggest a tendency for 
marital discord to be associated with running away. Only forty-four percent of the natural parents of runaways were still married, in contrast to $65 \%$ of the non-runaway control group.

TABLE VIII

Frequency and Percentage Distribution of Marital Status of Natural Parents Married Compared to All Other Categories

\begin{tabular}{|c|c|c|c|c|c|c|c|c|}
\hline \multirow{2}{*}{$\begin{array}{l}\text { MARITAL } \\
\text { STATUS }\end{array}$} & \multicolumn{2}{|c|}{ Contact } & \multicolumn{2}{|c|}{ Court } & \multirow{2}{*}{\multicolumn{2}{|c|}{ AाT Runaways }} & \multicolumn{2}{|c|}{ Control } \\
\hline & No. & $\%$ & No. & $\%$ & & $\%$ & No. & $\%$ \\
\hline Married & 12 & 57 & 19 & 40 & 31 & 44 & 22 & 65 \\
\hline $\begin{array}{l}\text { Other } \\
\text { (Divorced, } \\
\text { Separated, } \\
\text { etc.) }\end{array}$ & 9 & 43 & 31 & 60 & 40 & 56 & 12 & 35 \\
\hline Total & 21 & 100 & 50 & 100 & 71 & 100 & 34 & 100 \\
\hline$n=71 \quad$ p>.05 & $x^{2}=$ & & d.f. $=1$ & & & $\begin{array}{l}=105 \\
k 2=3.45\end{array}$ & $\begin{array}{l}p>0 \\
\text { d.f. }\end{array}$ & \\
\hline
\end{tabular}

Available demographic data on divorce and separation in Multnomah County did not allow for a direct comparison of either our experimental or control group with the characteristics of the general population. Data from the 1970 Census indicates that $10.8 \%$ of all persons in Multnomah County who were ever married are divorced.55 In 1971 there were 3,543 divorces in Multnomah County, or 6.3 divorces per 1000 population. 56 It could be concluded that the breakdown of nuclear families is not specialized to the runaway population, but is common among the general community. 
TABLE IX

Length of Time Parents Have Been Separated or Divorced

\begin{tabular}{|c|c|c|c|c|c|c|c|c|c|c|}
\hline & & $\overline{a c t}$ & & & & rol & Non- & ronic & & nic \\
\hline & No. & $\%$ & No. & $\%$ & No. & $\%$ & No. & $\%$ & No. & $\%$ \\
\hline $\begin{array}{l}\text { Less th } \\
1 \mathrm{yr} .\end{array}$ & ${ }^{n} 0$ & 0 & 0 & 0 & 0 & 0 & 0 & 0 & 0 & 0 \\
\hline $\begin{array}{c}1 \text { to } 5 \\
\text { yrs. }\end{array}$ & 2 & 10 & 5 & 10 & 2 & 6 & 3 & 8 & 4 & 11 \\
\hline $\begin{array}{c}\text { More th } \\
5 \text { yrs. }\end{array}$ & ${ }^{n}$ & 5 & 10 & 20 & 5 & 15 & 4 & 11 & 7 & 19 \\
\hline $\begin{array}{l}\text { Not app } \\
\text { able }\end{array}$ & $\begin{array}{l}i c- \\
14\end{array}$ & 65 & 22 & 44 & 22 & 64 & 21 & 61 & 15 & 42 \\
\hline $\begin{array}{l}\text { No ansh } \\
\text { or } \\
\text { Don't } \\
\text { Know }\end{array}$ & 4 & 20 & 13 & 26 & 5 & 15 & 7 & 20 & 10 & 28 \\
\hline Total & 21 & 100 & 50 & 100 & 34 & 100 & 35 & 100 & 36 & 100 \\
\hline
\end{tabular}

Subjects who reported that their parents were divorced or separated were asked to specify the length of time since the divorce or separation had occurred. Current marital breakup did not appear as a contributing factor in the subject's probability of running away since no respondents (both runaway and non-runaway) listed marital breakup as occurring within the last year.

No statistical testing was applied to this data. However, frequencies for both runaway and non-runaway populations did indicate high percentages of marital break-up occurring more than five years from the time of the interview. This finding is no doubt indicative of marital breakdown occurring early in most marriages when the child is younger. The stress one would expect upon the child when his/her 
parents are experiencing severe conflict (i.e., divorce or separation) does not appear related to runaway behavior.

The twelve possibilities for living arrangements of the subjects were grouped for the purpose of analys is into the three categories shown in Table $X$. Eight-five percent of the non-runaway control group was living with one or both of their naturai parents, whereas, only 45\% of the combined runaway group was living with one or both of their natural parents at the time they left home.

TABLE $X$

Frequency and Percentage Distribution of Living Arrangement of Child Prior to Running Away

LVNG. Contact

Court

Control
Non-chronic Chrontc ARRANGE. No. $\%$ No. $\%$ No. $\%$ No. $\%$ No. $\%$

One or both natural

Fa.-Mo. 21 $42 \quad 29$ $85 \quad 11$ $53 \quad 21$ $59 \quad 11$ 30

One or both

Step-Fa.

or Mo. \&/

or Nat.

$\mathrm{Fa}$. or

Mo.

$13 \quad 26 \quad 5$

156

28

8

$27 \quad 11$

30

Foster

Parents,

Reltves,

Inst., Other

$16 \quad 32 \quad 0$

0

04

19

$6 \quad 14 \cdot 14$

40

$\begin{array}{lllllllllll}\text { Total } & 50 & 100 & 34 & 100 & 21 & 100 & 35 & 100 & 36 & 100\end{array}$

$\begin{array}{llll}n=105 \quad p<.05 \quad x^{2}=19.07 \quad \text { d.f. }=4 & \begin{array}{l}n=71 . \\ x^{2}=6.78\end{array} & \begin{array}{l}p<.05 \\ \text { d.f. }=2\end{array}\end{array}$


The computed Chi-square value for the question significantly related running away to a child's living arrangement and further substantiated the distinctions found in percentage comparisons. Test results clearly indicated a dependent relationship for both the runaways samples and the sub-grouping of chronic and non-chronic runaways between this variable and running away. (See Table $X$ )

Our data tends to counter the findings of a study on runaways in Salt Lake County, Utah, which suggested that "problems which could precipitate and cause a youth to run away from home are just as likely to occur in a home with both parents present as they are in other living arrangements." 57 On the contrary, the results of our study show a strong association between families that are not intact and runaway behavior.

Intact Families.

Differences between the runaway and control groups were also noted in comparing the respective numbers of youth living in "intact families." A family with both natural parents present or one natural parent and one step-parent was operationally defined as an "intact family," as opposed to single parent families, foster care, or institutional arrangements. The following percentages or subjects were found to be living in intact families: $82 \%$ of the control group; $71 \%$ of the Contact Center subjects; $52 \%$ of runaways at Juvenile Court; $60 \%$ of the non-chronic runaways; $55 \%$ of the chronic runaways.

Chi-square analysis of the runaway sample as compared to the control group resulted in a statistically significant relationship between running away and the lack of an intact family. Testing of 
the chronic and non-chronic runaway subgroups did not establish a dependent relationship between this variable and chronic runaway behavior. (See Table XI)

TABLE XI

Frequency and Percentage Distribution of Intact Family

\begin{tabular}{|c|c|c|c|c|c|c|c|c|}
\hline FAMILY & & way & Co & rol & Non- & ronic & $\mathrm{Ch}$ & nic \\
\hline TYPE & No. & $\%$ & No. & $\%$ & No. & $\%$ & No. & $\%$ \\
\hline Intact Family & 41 & 58 & 28 & 82 & 21 & 60 & 20 & 55 \\
\hline $\begin{array}{l}\text { All 0ther } \\
\text { Categories }\end{array}$ & 30 & 42 & 6 & 18 & 14 & 40 & 16 & 45 \\
\hline Total & 71 & 100 & 34 & 100 & 35 & 100 & 36 & 100 \\
\hline$n=105 \quad p<.05$ & $x^{2}=$ & & d. $f .=$ & & & & & $\begin{array}{l}5 \\
=1\end{array}$ \\
\hline
\end{tabular}

\section{Legal Custody}

Data on the legal custody of children who are not living with their natural parents showed $50 \%$ of the combined runaway population had legal custody with welfare, JDH, or other institutions. It should be noted that about one-third of the total runaway population was living with both their natural parents, and thus did not respond. Also, two court subjects and three non-runaways responded inappropriately, i.e., they were probably living with only one natural parent. All of the non-runaway population were in the legal custody of their natural parents, providing a striking contrast to the runaway group. When comparing the runaway subgroups, $38 \%$ of the non-chronic runaways and $68 \%$ of the chronic runaways were not in the legal custody of their 
natural parents. A Chi-square grouping of "institutional custody" tha (welfare, JDH, other institutions) vs. "parental and relative" custody showed no significant difference between chronic and nonchronic runaways, although chronic runaways were more likely $162 \%$ vs. $40 \%$ ) to be in the custody of an institution. This same analysis was done between runaways and non-runaways resulting in a significant difference.

TABLE XII

Frequency and Percentage Distribution of Person Having Legal Custody if Subject Not Living With Natural Parents

\begin{tabular}{|c|c|c|c|c|c|c|c|c|c|c|}
\hline LEGAL & & $\operatorname{act}$ & & & & 01 & Non- & ronic & & nic \\
\hline CUSTODY & No. & $\%$ & No. & $\%$ & No. & $\%$ & No. & $\%$ & No. & $\%$ \\
\hline $\begin{array}{l}\text { Natural } \\
\text { Parent ol } \\
\text { Relative }\end{array}$ & $r_{4}$ & 19 & 19 & 38 & 8 & 25 & 13 & 36 & 10 & 28 \\
\hline $\begin{array}{l}\text { Wel fare, } \\
\text { JDH, } \\
\text { Other }\end{array}$ & 7 & 33 & 16 & 32 & 0 & 0 & 8 & 27 & 15 & 41 \\
\hline $\begin{array}{l}\text { Not Ap- } \\
\text { plic. }\end{array}$ & 10 & 48 & 15 & 30 & 26 & 75 & 14 & 37 & 11 & 31 \\
\hline Total & 21 & 100 & 50 & 100 & 34 & 100 & 35 & 100 & 36 & 100 \\
\hline$n=71$ & & & $\star \times 2$ & .96 & d. & & & $\begin{array}{l}6 \\
2.19\end{array}$ & & \\
\hline
\end{tabular}

Visitation of Subject Not Living With Natural Parents

Because there was only one subject within the control group for which visitation with either the natural mother or natural father applied, it is evident that the vast majority of these youth were living 
with their natural parents; this is supported by the responses to the question regarding living arrangement. In determining frequency of visitation with the natural mother for the Contact sample $(n=5)$, it was found that 40 percent of the subjects visited often or occasionally while 60 percent visited seldom or not at all. Within the juvenile court sample $(n=20), 70$ percent visited often or occasionally with the natural mother and 30 percent visited seldom or not at all. Visitation with the natural father was overwhelmingly found to occur seldom or not at all (100 percent for the Contact sample and 63 percent for the court sample). There was no significant difference between the Contact Center and the court sample or between chronic and non-chronic runaways regarding the frequency of visits with their natural parents.

TABLE XIII

Frequency and Percentage Distribution of Visitation With Absent Father

VISITS Contact Court Control Non-chronic Chronic

FATHER No. $\%$ No. $\%$ No. $\%$ No. $\%$ No. $\%$

Often or

Occasion-

ally

0

$0 \quad 7$

$31 \quad 1 \quad 100$

$2 \quad 20$

5

38

Seldom

or not

at all

$\begin{array}{lll}4 & 100 \quad 12\end{array}$

63

0

8

$80 \quad 8$

62

Total $\quad 4 \quad 100 \quad 19$

$n=23$

$$
\text { p).05 } \quad * x^{2}=2.11
$$

d.f. $=1$

100

10

100

$13 \quad 100$

*Chi-square value pertains to comparison of

Court and Contact Center only; "not applic-.

able or no answer" frequencies were not

included in test. 
TABLE XIV

Frequency and Percentage Distribution of Visitation With Absent Mother

\begin{tabular}{|c|c|c|c|c|c|c|c|c|c|c|}
\hline \multirow{2}{*}{$\begin{array}{l}\text { VISITS } \\
\text { MOTHER } \\
\end{array}$} & \multicolumn{2}{|c|}{ Contact } & \multicolumn{2}{|c|}{ Court } & \multicolumn{2}{|c|}{ Control } & \multicolumn{2}{|c|}{ Non-chronic } & \multicolumn{2}{|c|}{ Chronic } \\
\hline & No. & $\%$ & No. & $\&$ & No. & $\&$ & No. & $\&$ & No. & $\&$ \\
\hline $\begin{array}{l}\text { Often or } \\
\text { Occasion } \\
\text { ally }\end{array}$ & 2 & 40 & 14 & 70 & 0 & 0 & 4 & 50 & 12 & 71 \\
\hline $\begin{array}{l}\text { Seldom } \\
\text { or not } \\
\text { at all }\end{array}$ & 3 & 60 & 6 & 30 & 1 & 100 & 4 & 50 & 5 & 29 \\
\hline Total & 5 & 100 & 20 & 100 & 1 & 100 & 8 & 100 & 17 & 100 \\
\hline$n=25$ & \multicolumn{2}{|c|}{$p>.05$} & \multicolumn{2}{|c|}{$\star x^{2}=1.56$} & \multicolumn{2}{|c|}{ d.f. $=1$} & \multicolumn{2}{|c|}{$n=25$} & \multicolumn{2}{|c|}{ p>.05 } \\
\hline \multicolumn{7}{|c|}{$\begin{array}{l}\text { *Chi-square value pertains to comparison } \\
\text { of Court and Contact Center only; "not } \\
\text { applicable or no answer" frequencies } \\
\text { were not included in the test. }\end{array}$} & \multicolumn{2}{|c|}{$x^{2}=1.00$} & \multicolumn{2}{|c|}{ d.f. $=1$} \\
\hline
\end{tabular}

Subject's Feeling Toward Parent(s) (or Institution)

Interval data was obtained on this question from scaled responses which ranged from "dislike" to "love." Analysis of variance was completed on the group means of the Court, Contact, and Control samples; a separate computation was made for the chronic and non-chronic runaways.

Analysis of variance of the Court, Contact Center, and control group means indicate that a youngster's feelings toward his parents (or the institution in which he has been placed) have a statistically significant influence on runaway behavior. This finding would tend to counter the claims of earlier writers that running away is a natural phenomenon or youth, motivated by a spirit of adventure rather 
than any particular conflict in life. 58

Contact Center runaways, with a low group mean of 3.76 , held the most negative attitude toward their parents or foster parents. Since the majority of the court runaways had been held, at least briefly in detention, it was speculated that the experience of apprehension and incarceration may have temporarily altered their attitude toward the home or institution which they had left.

TABLE XV

\section{Analysis of Variance: Subject's Feelings Toward Parents (or Institution) He Was Living With}

\begin{tabular}{|c|c|c|c|c|}
\hline $\begin{array}{l}\text { Sample } \\
\text { Group }\end{array}$ & $\begin{array}{l}\text { Number of } \\
\text { Subjects }\end{array}$ & $\begin{array}{l}\text { Total } \\
\text { Score }\end{array}$ & $\begin{array}{c}\text { Mean } \\
\text { Average }\end{array}$ & $\begin{array}{l}\text { Analysis } \\
\text { of Variance } \\
\end{array}$ \\
\hline Court & 50 & 311 & 6.22 & $n=105$ \\
\hline Contact & 21 & 78 & 3.76 & $p<.05$ \\
\hline Control & 34 & 301 & 8.85 & $F_{102}^{2}=10.63$ \\
\hline Non-chronic & 35 & 200 & 5.71 & $n=71$ \\
\hline Chronic & 36 & 190 & 5.28 & $F l_{69}=.39$ \\
\hline \multicolumn{5}{|c|}{ 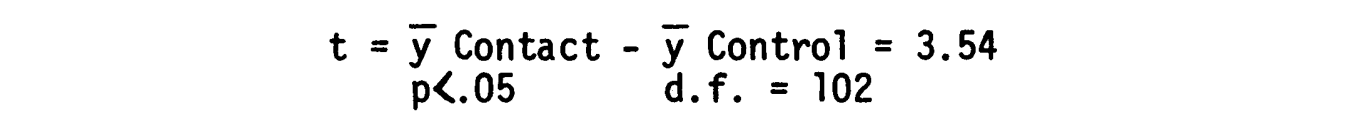 } \\
\hline - & \multicolumn{4}{|c|}{$\begin{array}{c}t={ }_{\text {p }} \bar{y} \text { Court }-\bar{y} \text { Control }=4.43 \\
\text { d.f. }=102\end{array}$} \\
\hline
\end{tabular}

Variance in the group means of the chronic and non-chronic runaways in relation to the variability between each group was not greater than that expected by chance.

A comparison of the Contact Center group mean versus the control 
group showed a significant difference between the two sample groups. Likewise, analysis of the control group and Juvenile Court subjects established that the court group was significantly more negative in their attitude toward their parents. How Subject Thinks Parent(s) Feel Toward Him

Interval data on this variable was obtained from the same type of hate-love scale used in the preceding question on the subject's feeling toward his parent(s).

\section{TABLE XVI}

Analys is of Variance: How Subject Thinks Parent(s) Feel Toward Him

\begin{tabular}{|c|c|c|c|c|}
\hline $\begin{array}{l}\text { Sample } \\
\text { Group }\end{array}$ & $\begin{array}{l}\text { Number of } \\
\text { Subjects }\end{array}$ & $\begin{array}{l}\text { Total } \\
\text { Score } \\
\end{array}$ & $\begin{array}{c}\text { Mean } \\
\text { Average }\end{array}$ & $\begin{array}{l}\text { Analysis } \\
\text { of Variance }\end{array}$ \\
\hline Court & 50 & 329 & 6.58 & $n=105$ \\
\hline Contact & 21 & 113 & 5.38 & $p<.05$ \\
\hline Control & 34 & 311 & 9.10 & $F_{102}^{2}=18.28$ \\
\hline Non-chronic & 35 & 209 & 5.97 & $n=71$ \\
\hline Chronic & 36 & 227 & 6.31 & $F_{69}^{P}=.24$ \\
\hline
\end{tabular}

Analys is of variance of the Juvenile Court and Contact Center samples showed that a youngster's perception of how his parents feel toward him bears a statistically significant relationship to running away. It should be noted that the high school control sample's group mean was 9.1 on a 10-point scale. Contact Center runaways with a low mean of 5.38 , held the most negative opinion of the nature of their relationship with their parents or guardian. 
The group means for chronic and non-chronic runaways were very similar for this question and, therefore, statistical testing did not establish a relationship between this variable and chronic runaway behavior.

Number of Siblings

The average number of siblings for the two experimental samples, the control subjects, and the two runaway sub-groupings was calculated from the total number of siblings belonging to each respective group. The averages shown on Table 17 indicate that Contact Center runaways tend to have the smallest number of siblings in their families. This finding supports the observations of the agency staff that the runaway program is utilized primarily by middle and upper-middle class youth who tend to come from smaller families.

TABLE XVII

Frequency Distribution of Total Number of Sibling and Percentage Distribution of Unnatural Siblings

\begin{tabular}{lccccc}
\hline $\begin{array}{l}\text { Sample } \\
\text { Group }\end{array}$ & $\begin{array}{c}\text { Total } \\
\text { Subjects }\end{array}$ & $\begin{array}{c}\text { Total } \\
\text { Siblings }\end{array}$ & $\begin{array}{l}\text { Average \# } \\
\text { Siblings }\end{array}$ & $\begin{array}{c}\text { Unnatural } \\
\text { Siblings }\end{array}$ & $\begin{array}{c}\text { \% Unnat. } \\
\text { Siblings }\end{array}$ \\
\hline Contact & 21 & 50 & 2.4 & 18 & .36 \\
Court & 50 & 159 & 3.2 & 52 & .33 \\
Control & 34 & 104 & 3.1 & 20 & .19 \\
\hline Non-chrorric & 35 & 101 & 2.9 & 21 & .21 \\
Chronic & 36 & 109 & 3.0 & 49 & .45 \\
\hline
\end{tabular}

$n=71 \quad p_{<} 05 \quad \star_{z}=3.89$

* $z$ score applies only to the comparison of the percentage of unnatural siblings in the chronic and non-chronic categories. 
Statistical testing on the sibling data focused on the difference between groups in regard to the number of unnatural siblings. An "unnatural sibling" was operationally defined as a step-brother or sister, a half-brother or sister, or foster sibling. Our supposition was that the frequency of unnatural siblings occurring in each group would serve as an opproximate measure of deviation from an undisrupted nuclear family structure.

Percentage comparisons of chronic versus non-chronic runaways showed that chronic runaway had a significantly higher ratio of unnatural siblings in their families. This finding may correlate with the earlier data on marital status which showed that $73 \%$ of the parents of chronic runaways were divorced, widowed, or never married.

Ordinal Position

Chi-square analysis of the oldest and youngest children in the combined runaway group and in the two subgroups did not establish a statistically significant relationship between ordinal position in the family and runaway behavior.

TABLE XVIII

Frequency and Percentage Distribution of Ordinal Positions

\begin{tabular}{|c|c|c|c|c|c|c|c|c|}
\hline \multirow{2}{*}{$\begin{array}{l}\text { Ordinal } \\
\text { Position }\end{array}$} & \multirow{2}{*}{\multicolumn{2}{|c|}{$\begin{array}{l}\text { Combined Runaways } \\
\text { No. \% }\end{array}$}} & \multicolumn{2}{|c|}{ Control } & \multirow{2}{*}{\multicolumn{2}{|c|}{ Non-chronic }} & \multicolumn{2}{|c|}{ Chronic } \\
\hline & & & No. & $\%$ & No. & & No. & $\%$ \\
\hline 01 dest & 25 & 35 & 7 & 21 & 10 & 28 & 15 & 42 \\
\hline Youngest & 14 & 20 & 9 & 26 & 8 & 23 & 6 & 16 \\
\hline $\begin{array}{l}\text { Middle } \\
\text { Or Not } \\
\text { Applicable }\end{array}$ & 32 & 45 & 18 & 53 & 17 & 49 & 15 & 42 \\
\hline Total & 71 & 100 & 34 & 100 & 35 & 100 & 36 & 100 \\
\hline $\begin{array}{l}n=105 \\
\text { *Chi-squ } \\
\text { parison } \\
\text { positiol }\end{array}$ & $\begin{array}{l}\text { p>.05 } \\
\text { e value } \\
\text { f the } 0 \\
\text {. }\end{array}$ & $\begin{array}{l}* x^{2}=1.93 \\
\text { ertains on } \\
\text { est and yo }\end{array}$ & $\begin{array}{l}d \\
\text { to }\end{array}$ & & & 1.27 & & $\begin{array}{l}05 \\
=1\end{array}$ \\
\hline
\end{tabular}


Preliminary data suggesting a tendency for the youngest child in a family to be more less the larger samples responding to the final questionnaire.

Percentage distributions did suggest that chronic runaways were not likely to be the youngest child in the family. Consideration of the combined runaway group versus the control subjects indicated that runaways are more often the oldest rather than the youngest child in the family.

Parental Treatment of Subject in Relation to Siblings

The computed Chi-square value for Contact Center, Court, and control subjects who stated that their parents treated them either better or worse in relation to siblings significantly related perceived parental treatment and runaway behavior. Forty-four percent of the total runaway sample as compared to only $6 \%$ of the control group felt that their parents treated them worse in relation to siblings.

Furthermore, the issue of equitable treatment from parents is undoubtedly an important factor in a youngster's general feelings toward his parents. Data from this question, when viewed in conjunction with the findings from the inquiry about subjects' feelings toward his parents, would strongly suggest that a poor relationship with parents is a major contributor to running away. This phenomena of differential treatment may be enhanced by the finding of more unnatural siblings occurring in runaway families.

The Chi-square value for chronic and non-chronic runaways was not sufficient to establish a dependent relationship between the 
subjects' perception of parental treatment of self in relation to siblings and chronic runaway behavior.

\section{TABLE XIX}

Frequency and Percentage Distribution of Parental Treatment Of Subject In Relation To Siblings

\begin{tabular}{|c|c|c|c|c|c|c|c|c|c|c|}
\hline \multirow{2}{*}{$\begin{array}{l}\text { PARNTL } \\
\text { TRTMT } \\
\end{array}$} & \multicolumn{2}{|c|}{ Contact } & \multicolumn{2}{|c|}{ Court } & \multicolumn{2}{|c|}{ Control } & \multicolumn{2}{|c|}{ Non-chrontc } & \multicolumn{2}{|c|}{ Chrontc } \\
\hline & No. & $\%$ & No. & $\%$ & No. & $\%$ & No. & $\%$ & No. & $\%$ \\
\hline Same & 6 & 25 & 27 & 54 & 27 & 79 & 16 & 46 & 17 & 47 \\
\hline Better & 0 & $\mathrm{c}$ & 3 & 6 & 3 & 9 & 1 & 3 & 2 & 6 \\
\hline Worse & 12 & 57 & 19 & 38 & 2 & 6 & 14 & 40 & 17 & 47 \\
\hline $\begin{array}{l}\text { Differen } \\
\text { or not } \\
\text { Applic. }\end{array}$ & 3 & 14 & 1 & 2 & 2 & 6 & 4 & 11 & 0 & 0 \\
\hline Total & 21 & 100 & 50 & 100 & 34 & 100 & 35 & 100 & 36 & 100 \\
\hline & \multicolumn{2}{|c|}{ p<. 05} & \multicolumn{2}{|c|}{$* x^{2}=20.59$} & \multicolumn{2}{|c|}{ d. $f .=4$} & \multicolumn{2}{|c|}{$\begin{array}{l}n=67 \\
\text { d.f. }=1\end{array}$} & \multicolumn{2}{|c|}{$\begin{array}{l}p>.05 \\
x^{2}=.29\end{array}$} \\
\hline $\begin{array}{l}{ }^{*} \text { Chi- } \\
\text { pari }\end{array}$ & & & $r t$ & & to & c & & & & \\
\hline
\end{tabular}

\section{Trust Between Parent and Child}

Another variable that was believed to be an important factor in family relationships is the amount of trust between parent and child. In many respects, a continuum response scale focusing on trust was thought to be a more comprehensive measure of conflict regarding decision-making authority than data about how specific issues are decided. Subjects were asked to indicate both how much they feit their parents trusted them as well as how much they trusted their parents. Possible responses ranged from "distrust" to "trust completely." 
TABLE XX

Analys is of Variance: How Subject Feels Parent(s) Trusts Him

\begin{tabular}{|c|c|c|c|c|}
\hline $\begin{array}{l}\text { Sample } \\
\text { Group }\end{array}$ & $\begin{array}{l}\text { Number of } \\
\text { Subjects }\end{array}$ & $\begin{array}{l}\text { Total } \\
\text { Score }\end{array}$ & $\begin{array}{c}\text { Mean } \\
\text { Average }\end{array}$ & $\begin{array}{c}\text { Analysis } \\
\text { of Variance }\end{array}$ \\
\hline Court & 50 & 187 & 3.59 & $n=105$ \\
\hline Contact & 21 & 62 & 2.95 & $p<.05$ \\
\hline Control & 34 & 259 & 7.60 & $F_{102}^{2}=31.66$ \\
\hline Non-chronic & 35 & 118 & 3.69 & $n=71$ \\
\hline chronic & 36 & 110 & 3.36 & $F_{69}^{1^{p>}=.05}$ \\
\hline
\end{tabular}

Analysis of variance on the question of parental trust showed a statistically significant relationship between the variable and runaway behavior. Contact Center subjects perceived their parents as trusting them far less than the non-runaway control group thought their parents trusted them. The Juvenile Court runaways rated parental trust only slightly higher than did the Contact Center group. Variance in the group means of chronic and non-chronic runaways was not sufficient to establish a dependent relationship between parental trust and running away.

The importance of mutual trust between parent and adolescent was further substantiated by testing of interval data showing how much the young person trusts his own parents. Analysis of variance of group means from Contact Center, control group and Juvenile Court showed that variabllity between groups was far greater than could be expected by chance. Contact Center subjects placed far less trust in their parents than did the control group; Juvenile Court 
runaways trusted their parents somewhat more than the Contact Center subjects. Test results on the chronic and non-chronic runaway groups again did not establish a statistically significant relationship between a youngster's trust in his parents and running away.

TABLE XXI

Analys is of Variance: Subject's Trust of Parent(s)

\begin{tabular}{|c|c|c|c|c|}
\hline $\begin{array}{l}\text { Sample } \\
\text { Group }\end{array}$ & $\begin{array}{l}\text { Number of } \\
\text { Subjects }\end{array}$ & $\begin{array}{l}\text { Total } \\
\text { Score }\end{array}$ & $\begin{array}{c}\text { Mean } \\
\text { Average } \\
\end{array}$ & $\begin{array}{c}\text { Analysis } \\
\text { of Variance } \\
\end{array}$ \\
\hline Court & 50 & 281 & 5.62 & $n=105$ \\
\hline Contact & 21 & 91 & 4.30 & p<.05 \\
\hline Control & 34 & 300 & 8.80 & $\mathrm{~F}_{102}^{2}=22.94$ \\
\hline Non-chronic & 35 & 182 & 5.20 & $n=71$ \\
\hline Chronic & 36 & 192 & 5.33 & $F_{69}^{1 p>.05}$ \\
\hline
\end{tabular}

As with the pair of questions concerning the general tenor of feelings between parents and child, the testing of trust between parents and child was able to distinguish significant variables between the total runaway sample and non-runaways. However, analys is of variance of the two subgroup means did not result in the identification of a statistically significant relationship between trust or feelings and chronic runaway behavior.

Significant Other Adults

A majority of both the runaway and non-away subjects stated that they did have an adult with whom they could discuss important matters. However, a higher percentage of the control group (68\%), as compared to the combined runaway sample (56\%)answered the question affirmatively. 
Chi-square testing of only the chronic and non-chronic runaways (excluding subjects who responded in the "other" category) established a statistically significant relationship between this variable and repetitive running away. Youngsters who do not have a trusted adult to talk with were more likely to engage in chronic runaway behavior.

\section{TABLE XXII}

Frequency and Percentage Distribution of Adults With Whom Important Matters Are Discussed

\begin{tabular}{|c|c|c|c|c|c|c|c|c|c|c|}
\hline \multirow{2}{*}{\multicolumn{3}{|c|}{ ADULTS T0 Contact }} & \multicolumn{2}{|c|}{ Court } & \multicolumn{2}{|c|}{ Control } & \multicolumn{2}{|c|}{ Non-chronic } & \multicolumn{2}{|c|}{ Chronic } \\
\hline TALK TO & & $\%$ & No. & $\%$ & No. & $\%$ & No. & $\%$ & No & $\%$ \\
\hline Yes & 11 & 52 & 29 & 58 & 23 & 68 & 24 & 68 & 16 & 45 \\
\hline No & 8 & 38 & 19 & 38 & 11 & 32 & 9 & 26 & 18 & 50 \\
\hline $\begin{array}{l}\text { Other } \\
\text { (non- } \\
\text { adult) }\end{array}$ & 2 & 9 & 2 & 4 & 0 & 0 & 2 & 6 & 2 & 5 \\
\hline Total & 21 & 100 & 50 & 100 & 34 & 100 & 35 & 100 & 36 & 100 \\
\hline & & & & & 8 & & & & & \\
\hline
\end{tabular}

How Long Was Subject on the Run

Our data on the length of time that a youngster stays on the run from his home (or institution) tends to support the findings of other researchers that such episodes are poorly planned and of brief duration. 59 Another interpretation of the short time away from home implies that runaway behavior is more an attempt to call attention to an unsatisfactory home situation than a desire to leave home. ${ }^{60}$ 
Two-thirds of the Contact Center sample and nearly $60 \%$ of the court runaways were on the run for one week or less.

TABLE XXIII

Frequency and Percentage Distribution For How Long Subject Was on the Run

\begin{tabular}{lrrrrrrrrr}
\hline \multirow{2}{*}{} & \multicolumn{2}{c}{ Contact } & \multicolumn{2}{c}{ Court } & \multicolumn{3}{c}{ Non-chronic } & \multicolumn{2}{c}{ Chronic } \\
TIME & No. & \multicolumn{1}{c}{ No. } & $\%$ & No. & $\%$ & No. & $\%$ \\
\hline Less than one week & 14 & 67 & 29 & 58 & 21 & 60 & 22 & 61 \\
One - Two weeks & 2 & 10 & 7 & 14 & 3 & 11 & 6 & 17 \\
Two - Four weeks & 2 & 10 & 6 & 12 & 6 & 17 & 2 & 6 \\
Four weeks or more & 1 & 3 & 3 & 6 & 1 & 3 & 3 & 8 \\
Other or no answer & 2 & 10 & 5 & 10 & 4 & 9 & 3 & 8 \\
Total & 21 & 100 & 50 & 100 & 35 & 100 & 36 & 100 \\
\hline
\end{tabular}

The undetermined number of runaways who do not seek help from voluntary social service agencies or who are not referred to Juvenile Court may comprise a group of youngsters with greater resources and more sophistication in their plans to run away. We have speculated, therefore, that it may be this unidentified population of runaways who are the youth that stay away from home for longer periods or fail to return home at all.

\section{Previous Runaway Experiences}

Juvenile Court subjects had an average of 3.12 previous runaway episodes as compared to an average of 2.00 prior runaway experiences for the Contact Center group. However, the analysis of variance was not sufficient to establish a statistically significant difference in the group means. Fifty-eight percent of the Juvenile Court runaways 
were chronic as compared to only $33 \%$ of the Contact Center runaways. This would imply that Contact runaways have had less runaway experience than kids who are referred to Juvenile Court.

TABLE XXIV

Frequency and Percentage Distribution of Previous Runaway Experiences

\begin{tabular}{|c|c|c|c|c|c|c|c|c|}
\hline Number of & & $\mathrm{act}$ & & & Non- & ronic & & nic \\
\hline Previous Runs & No. & $\%$ & No. & $\%$ & No. & $\%$ & No. & $\%$ \\
\hline None - two & 14 & 66 & 21 & 42 & 35 & 100 & 0 & 0 \\
\hline Three - Five & 5 & 24 & 21 & 42 & 0 & 0 & 26 & 72 \\
\hline Six - Elght & 1 & 5 & 5 & 10 & 0 & 0 & 6 & 17 \\
\hline Nine or More & 1 & 5 & 3 & 6 & 0 & 0 & 4 & 11 \\
\hline Total & 21 & 100 & 50 & 100 & 35 & 100 & 36 & 100 \\
\hline Means & & & & & & & & \\
\hline$=71$ & .05 & & 2 & & $. f .=6$ & & & \\
\hline
\end{tabular}

Thirty-eight percent of the Contact Center runaways in contrast to $16 \%$ of the court group had not previously run away from home. Since a majority of the subjects from both agencles had had at least one other runaway experience, it would appear that once running away has been tried, it is likely to be a recurrent method of coping with problems.

Although our research was not designed to evaluate the effectiveness of service from either agency, this data does draw attention to the question of the efficacy of social services in deterring repeated runaway behavior. The finding of a study of runaways in Salt Lake 
County, Utah, clearly indicated that "youth who are running away from home are not aware of services which are available to them." 61 Furthermore, it was found that of "those youth who had contact with a social agency offering personal counseling services almost two-thirds (63 percent) stated that they had not been helped with their problems. "62 Therefore, a dual problem confronts those who wish to help runaways develop alternate ways of handling their difficulties: 1) a lack of awareness of services on the part of youth, and 2) a lack of serviceeffectiveness once help is sought.

Event That Precipitated Runaway

In assessing the reasons for the subject running away, no significant difference occurred between court and Contact; and chronics vs. non-chronic runaways.

TABLE XXV

Frequency and Percentage Distribution of Event That Precipitated Runaway

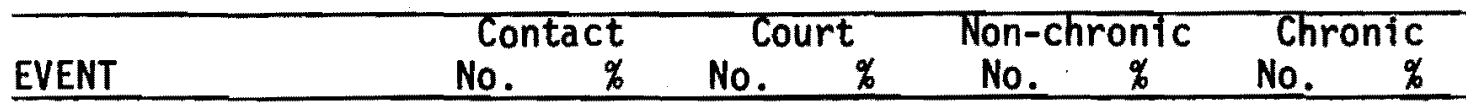

Fight with parents, sibling, or change in marital status of parents 10 $48 \quad 28$ $56 \quad 18$ $52 \quad 20$ 56

Kicked out, law violation, nothing specific. 2

other, no answer

$\begin{array}{lll}9 & 43 \quad 10\end{array}$ $24 \quad 6$ $17 \quad 8$ 22

Total $21 \quad 100$ 100 $\begin{array}{llllll}50 & 100 & 35 & 100 & 36 & 100\end{array}$

$\begin{array}{lllll}n=71 \quad p>.05 & x^{2}=4.65 & \text { d.f. }=2 & \begin{array}{l}n=71 \\ x^{2}=1.24\end{array} & \begin{array}{l}p>05 \\ \text { d.f. }=2\end{array}\end{array}$


Thus, the actual result of this particular question is that a majority of the runaways (55\%) ran away from home because of a family fight or conflict--(Category 1, 2, 4). Furthermore, exactly $50 \%$ of the court runaways gave "fight w/parents" as the reason for running away, while $38 \%$ of the Contact runaways gave that reason. These findings are representative of other questions concerning the runaway's attitude toward his family. Certainly the family adjustment is critically important in determining whether a child will run away from home. Has Subject Ever Been to Juvenille Court

Statistical testing of the Court and Contact runaways resulted in no significant difference between the populations. However, $72 \%$ of the Court runaways had been to Juvenile Court versus $57 \%$ of the Contact sample.

TABLE XXVI

Frequency and Percentage Distribution of Previous Juvenile Court Contacts

\begin{tabular}{|c|c|c|c|c|c|c|c|c|c|c|}
\hline $\begin{array}{l}\text { Been to } \\
\text { Juventle }\end{array}$ & $\mathrm{Co}$ & act & & & & rol & Non- & ronic & Ch & nic \\
\hline Ct. Bfr. & No. & $\%$ & No. & $\%$ & No. & $\%$ & No. & $\%$ & No. & $\%$ \\
\hline Yes & 12 & 57 & 36 & 72 & 0 & 0 & 16 & 46 & 32 & 89 \\
\hline No & 9 & 43 & 14 & 28 & 34 & 100 & 19 & 54 & 4 & 11 \\
\hline Total & 21 & 100 & 50 & 100 & 34 & 100 & 35 & 100 & 36 & 100 \\
\hline$n=71$ & & & * & & & & & 1.5 .10 & & $\begin{array}{l}05 \\
=1\end{array}$ \\
\hline
\end{tabular}

This may suggest that the recidivism to Juvenile Court agencies is quite high for runaways. Certainly a majority of the runaways sampled 
had been to a social agency before, and had apparently not received effective intervention. Comparison of the chronic vs. non-chronic runaways resulted in.a high significant difference in terms of previous Juvenile Court contact. While less than half of the non-chronics had been to Juvenile Court, an overwhelming $89 \%$ of the chronic runaways had previous Court contact. Even more conclusive is that all of the non-runaway population denied any previous Court contact. This finding generally supports the premise that runaways have a high probability of referral to Juvenile Courts as opposed to non-runaways. Why Referred to Juventle Court

In assessing the reasons for referral to Juvenile Court, a comparison was made between non-status versus status offenses (running away, truancy, curfew, and drinking). Between Court and Contact Center, there was a significant difference among status offenses, with 72\% of the Court population being referred for status offenses and only $33 \%$ of the Contact population referred for this reason. It appears that Contact runaways may have more serious delinquent involvement than the Court runaway population. Perhaps the reporting accuracy of Juvenile Court referrals varied greatly between the two runaway populations. In comparing the chronic versus non-chronic groups, no significant difference was found, al though $44 \%$ of the nonchronic and $72 \%$ of the chronic runaways had been referred for status offenses. This supports the recurrent behavior pattern of runaways tending to run away more than once, and furthermore not being likely to become involved in serious delinquency. Sixty-nine percent of the Court runaways had been referred for runaway while only $33 \%$ of the 
Contact population for this reason. No data was applicable on the control group and thus we did not compare runaways and non-runaways in this question. Several authors, such as Robins and 0 'Neal, ${ }^{63}$ and Nye and Short, ${ }^{64}$ have stressed the relationship between running away and other anti-social behavior. On the basis of our research, running away is not a valid predictor of serious delinquency, al though since running away is presently labeled delinquent behavior, runaways are likely to have previous and future delinquency.

TABLE XXVII

Frequency and Percentage of Status Offense Referrals To Juvenfle Court

\begin{tabular}{|c|c|c|c|c|c|c|c|c|}
\hline \multirow{2}{*}{$\begin{array}{l}\text { REASON FOR } \\
\text { REFERRAL } \\
\end{array}$} & \multirow{2}{*}{\multicolumn{2}{|c|}{$\begin{array}{l}\text { Contact } \\
\text { No. \& }\end{array}$}} & \multicolumn{2}{|c|}{ Court } & \multicolumn{2}{|c|}{ Non-chronic } & \multicolumn{2}{|c|}{ Chronic } \\
\hline & & & No. & $\&$ & No. & $\&$ & No. & $\&$ \\
\hline Status Offense & 4 & 33 & 26 & 72 & 7 & 44 & 23 & 72 \\
\hline Non-Status Offense & 8 & 67 & 10 & 28 & 9 & 56 & 9 & 28 \\
\hline Total & 12 & 100 & 36 & 100 & 16 & 100 & 32 & 100 \\
\hline$p<.05$ & & & d.f & & & 3.60 & & $\begin{array}{l}05 \\
.=1\end{array}$ \\
\hline
\end{tabular}

Trouble in School

Statistical testing was done to determine if a runaway was more likely to become in trouble in school than non-runaways, and this hypothes is was substantiated. Forty-one percent of the runaway population had been in trouble in school, while only $15 \%$ of the nonrunaways responded positively to the question. Comparison was done on the chronic versus non-chronic runaways and this resulted in no significant difference. Fifty percent of the chronic runaways had 
been in "trouble." This seemed to follow the trend of chronics versus non-chronics having little difference in character.

\section{TABLE XXVIII}

Frequency and Percentage Distribution of Subject Having Been In Trouble At School

\begin{tabular}{|c|c|c|c|c|c|c|c|c|c|c|}
\hline $\begin{array}{l}\text { Trouble } \\
\text { in }\end{array}$ & & act & & & & trol & Non- & rontc & & nic \\
\hline & No. & $\%$ & No. & $\%$ & No. & $\%$ & No. & q & No. & $\%$ \\
\hline Yes & 8 & 38 & 21 & 42 & 5 & 15 & 12 & 34 & 17 & 47 \\
\hline No & 12 & 57 & 28 & 56 & 29 & 85 & 23 & 66 & 17 & 47 \\
\hline $\begin{array}{l}\text { Not } \\
\text { Applic. } \\
\text { (out of } \\
\text { school) }\end{array}$ & 1 & 5 & 1 & 2 & 0 & 0 & 0 & 0 & 2 & 6 \\
\hline Tota 1 & 21 & 100 & 50 & 100 & 34 & 100 & 35 & 100 & 36 & 100 \\
\hline$n=71$ & & & $\star x^{2}$ & & & d.f. $=1$ & & $\begin{array}{l}9 \\
1.75\end{array}$ & & $\begin{array}{l}.05 \\
. x 1\end{array}$ \\
\hline
\end{tabular}

If Yes, What Kind of Trouble

No statistical testing was done on this particular question because of the wide variance in the responses and relative lack of applicability to the control group. It should be noted that over $50 \%$ of the Court runaways were in minor trouble $(1,3)$, and exactly $50 \%$ of the Contact runaways were in minor trouble. This pattern was not changed between the chronic and non-chronic groups, with nearly $50 \%$ of the non-chronic runaways and over $50 \%$ of the chronic runaways being in "minor trouble." Thus, the kind of trouble in school seemed constant throughout all groups of runaways. 


\section{TABLE XXIX}

Frequency and Percentage Distribution of Type of Trouble. in School

\begin{tabular}{|c|c|c|c|c|c|c|c|c|c|c|}
\hline Type of & & tact & & & & rol & Non- & ronic & & \\
\hline Trouble & No. & $\%$ & No. & $\%$ & No. & $\%$ & No. & $\%$ & No. & $q$ \\
\hline Truancy & 3 & 14 & 2 & 4 & 1 & 3 & 3 & 9 & 2 & 6 \\
\hline Assault & 0 & 0 & 4 & 8 & 0 & 0 & 1 & 3 & 3 & 8 \\
\hline $\begin{array}{l}\text { Breaking } \\
\text { School } \\
\text { Rules }\end{array}$ & 1 & 5 & 9 & 18 & 1 & 3 & 3 & 9 & 7 & 19 \\
\hline Expelled & 4 & 19 & 3 & 6 & 1 & 3 & 4 & 11 & 3 & 8 \\
\hline Drugs & 0 & 0 & 1 & 2 & 0 & 0 & 0 & 0 & 1 & 3 \\
\hline Other & 0 & 0 & 1 & 2 & 2 & 6 & 0 & 0 & 1 & 3 \\
\hline $\begin{array}{l}\text { Not } \\
\text { Applic. }\end{array}$ & 13 & 62 & 30 & 60 & 29 & 85 & 24 & 68 & 19 & 53 \\
\hline Total & 21 & 100 & 50 & 100 & 34 & 100 & 35 & 100 & 36 & 100 \\
\hline
\end{tabular}

How Subject Feels About School

Comparison was done between Court, Contact and the control group and a significant difference was found. Clearly the runaway populations exhibited more negative feelings than the control group and thus accounted for the statistical difference. No statistical test was done on the chronic versus non-chronic groups because of the minimal difference between means. It can safely be asserted that no difference in attitude toward school occurs between chronics and nonchronics. However, while $18 \%$ of the non-chronic group stated they absolutely "hate" school, $40 \%$ of the chronic group gave this response. This signifies a readiness for the chronic runaways to admit intensely 
negative feelings toward school.

TABLE $X X X$

Analys is of Variance: How Subject Feels Toward School

\begin{tabular}{lcccc}
$\begin{array}{l}\text { Sample } \\
\text { Group }\end{array}$ & $\begin{array}{c}\text { Number of } \\
\text { Subjects }\end{array}$ & $\begin{array}{c}\text { Tota } \\
\text { Score }\end{array}$ & $\begin{array}{c}\text { Population } \\
\text { Mean }\end{array}$ & $\begin{array}{c}\text { Analysis of } \\
\text { Variance }\end{array}$ \\
\hline Court & 50 & 211 & 4.22 & $\mathrm{n}=105$ \\
Contact & 21 & 98 & 4.67 & $\mathrm{p}<.05$ \\
Control & 34 & 216 & 6.35 & $\mathrm{~F}_{102}^{2}=4.63$ \\
\hline Non-chronic & 35 & 162 & 4.25 & No test \\
Chronic & 36 & 173 & 4.30 & \\
\hline
\end{tabular}




\section{CHAPTER 6}

CONCLUSIONS

\section{RESULTS}

This study has been concerned with determining significant characteristics between runaway and non-runaway populations, and the agencies which serve them. Data was recorded in both a preliminary and a final survey using different population samples. A combined runaway population of 71 subjects from Multnomah County Juvenile Court and Contact Center was utilized on the final survey; thirty-four nonrunaway Portland Public High School students served as the control population.

Three basic questions were established for consideration at the outset of this research study. These questions, given in the Introduction, are listed below with the findings from the final survey.

1. Are runaways significantly different from non-runaways in terms of the selected independent varjables? The following 15 variables were found to identify characteristics that occurred statistically more often $(*)$ in runaways or that showed a greater tendency to be associated with runaway behavior:

A. Sex--Runaways were likely to be female.

B. Parents' marital status--Runaways were likely to have natural parents not married to each other.

C. *Living Arrangement--Runaways not living with natural parents.

D. *Intact Family--Runaways not members of intact families.

E. *Legal Custody--Runaways were in institutional custody. 
F. *Feeling Toward Parents--Runaways had negative attitudes toward parents/or institution with whom they are living.

G. Siblings--Runaways were likely to have more "unnatural" siblings.

H. Ordinal Position--Runaways tended to be oldest child in family.

I. *Parental Treatment--Runaways felt they received worse treatment from parents in relation to other siblings.

J. *Subject's Trust in Parents--Runaways felt less trust toward parents.

K. *Parental Trust in Subjects--Runaways felt less trust from their parents.

L. Significant Other Adults--Runaways had fewer adults to talk to about important matters.

M. *Previous Court Referrals--Runaways had more Juvenile Court referrals.

N. "Trouble in School--Runaways experienced more "trouble" in school.

0. *Attitude Toward School--Runaways were likely to have a more negative attitude toward school.

2. Are Contact Center runaways significantly different from Juvenile Court runaways in terms of the selected independent variables? The following 10 variables were found to identify characteristics that occurred statistically more often ( $*$ ) in Contact Center runaways or that showed a greater tendency to be associated with runaways from 
Contact Center.

A. Race--Contact Center runaways are pre-dominantly Caucasian.

B. Area of Residency--Contact Center runaways are more likely to be Portland area residents.

C. Parents' Marital Status---Contact Center runaways' natural parents are more likely to be married.

D. Visitation with Absent Parent--Contact Center runaways, if not living with natural mother, tend to visit natural mother infrequently.

E. *Feelings Toward Parents--Contact Center runaways had more negative attitudes toward parent/or institution.

F. Siblings--Contact Center runaways tend to have fewer siblings.

G. *Parental Treatment--Contact Center runaway felt that they received worse treatment from parents in relation to other siblings.

H. Previous Runaway Experiences---Contact Center runaways were likely to have had fewer prior runaway experiences.

I. Previous Juvenile Court Referrals--Contact Center runaway tended not to have previous Juvenile Court referrals.

J. *Nature of Previous Juvenile Court Referral--Contact Center runaways were not referred for status offenses.

The combined data from three scaled response questions relating to parent-child relationships appears to support a trend for Contact Center runaways to hold considerably more negative attitudes toward their parents than did Juvenile Court runaways. For questions concerning how much the child trusted his parents, how much the child thought his parents trusted him, and how the child perceived his 
parents feeling toward him, our computed population means showed that Contact Center subjects were much less trustful of their parents and, in turn, generally believed that they were trusted and loved less than did the subjects at Juvenile Court.

3. Are chronic runaways significantly different from non-chronic runaways in terms of the selected independent variables? The following 10 variables were found to identify characteristics that occurred statistically more often $\left(^{*}\right)$ in chronic runaways or that showed a greater tendency to be associated with chronic runaway behavior:

A. *Age--Chrontc runaways were younger.

B. *Parents' Marital Status--Chronic runaways' natural parents were not married or were separated.

C. *Living Arrangements--Chronic runaways were living with foster parents, relatives, or in institutional settings.

D. Legal Custody--Chronic runaways were likely to be in the custody of an institution.

E. *Siblings--Chronic runaways had more "unnatural siblings."

F. Ordinal Position--Chronic runaways were not the youngest child in the family.

G. *Significant Other Aduits--Chronic runaways had fewer adults to talk with about important matters.

H. *Previous Juvenile Court Referrals--Chronic runaways had more previous Juvenile Court referrals.

I. Reason For Previous Juvenile Court Referral--Chronic runaways were more often referred for "status offenses."

J. Feelings About School--Chronic runaways had more negative 
attitudes toward school.

Furthermore, additional characteristics unique to the runaway population included the following:

1. Female runaways peaked at age 15, while male runaways peaked at age 16 (See Table IV).

2. Runaways were predominately in the freshman and sophomore classes in high school.

3. The precipitating event for running away was most often "family conflict."

4. Running away from home is a pattern of behavior likely to be repetitive.

5. When not living with natural father, runaways visited infrequently.

6. Runaways experienced "serious" trouble in school.

Information that was specific to Contact Center runaways based on the Preliminary Survey included the following:

1. Seventy-two percent of the runaways did not know about Contact Center before they left home.

2. Most of the runaways later learned of the agency from friends.

3. Reasons for coming to Contact Center were stated in very general terms, i.e., "to get help." (A previous comparative question found that the specific kind of help most often requested was assistance in finding a foster home or other living arrangement.)

4. Sixty percent of the group did not have any immediate plans, wished to return home (or to foster care), or simply wanted to "work out their problems," 
5. The future plans of $50 \%$ of the Contact Center subjects were either to continue with school or to find employment. Other runaways were unsure of their future plans or reported a highly individualized plan for the future.

\section{Impact For The Community}

With respect to the previously cited results, numerous implications can be drawn for runaways and the agencies which serve them. Using the differences between runaways and non-runaways, early identification of runaway-prone youth may be implemented. This would increase the effectiveness of prevention which typically has not been a focus for social service agencies. Particular attention must be given to family characteristics, relationship with parents, and school adjustment when considering preventative and treatment alternatives. The effect of the public school system upon a child's potential to run away appears to be significant. Youth who experience difficulty in adjusting to the school system have increased probability that they will become a runaway. Therefore, the runaway's family is not the only causal factor within the total environment of the runaway youth.

Using the differences between Contact Center and Juvenile Court, it becomes apparent that different social agencies receive client populations with differing characteristics, even when the "presenting problem" is identical. This phenomena suggests that prevention and treatment planning must consider the agency context rather than focusing only upon the social problem. General cross-agency differences between Contact and Juvenile Court occurred in areas of runaway's area of residency, race, family characteristics, relationship with 
parents, and previous runaway referrals and experience. Speculation of the research group that Contact Center is serving a more middleclass population than Juvenile Court, based on a number of siblings, economic information, and previous Court referrals was only substantiated in the final survey. It should be noted that this impression is far from conclusive; data in the preliminary survey suggested contradictory results. This inconsistency could be attributed to a non-representative sample in one or both of the surveys, or a changing characteristic in the client population.

The larger number of chronic runaways at Juvenile Court may suggest that, for the most part, Contact's runaways are less experienced in running away and manage to escape the juvenile justice system. Certainly the likelihood of being referred to court increases as a kid runs more times. Perhaps para-professional community agencies such as Contact Center offer more potential for reaching adolescents earlier in their anti-social and problematic behavior. The focus of efforts to develop preventative services for runaways and youth experiencing interpersonal conflict should be directed at highly accessible points in the community, i.e., the public schools.

The characteristics which distinguish chronic from non-chronic runaways bear a striking similarity to the variables which differentiate runaways from non-runaways. Eight out of the ten variables (80\%) resulting in differences between the chronic and non-chronic runaway were also common to the characteristics of runaways. These results show that chronic runaways are experiencing poorer family situations, and more negative attitudes toward school, than their non-chronic counterparts. Characteristics significant to runaways are qualitatively 
and quantitatively similar in their cumulative effect upon determining the extent of runaway involvement. Also the high frequency of chronic runaways in our runaway population suggests the recurring pattern of runaway behavior. While no conclusive remarks can be given about the treatment of this behavior, it can certainly be assumed that effective intervention is not being accomplished. Runaways are for the most part not a "delinquent" group of adolescents who become involved in behavior destructive to the community.

Implications For Future Research

On the basis of the findings of this study, several recommendations can be made for further research on the problem of runaway youth. As noted in the discussion of delimiting features of this study, our sampling procedure did not allow for a comparison of services provided to runaways at Juvenile Court and Contact Center. Information on the nature of current services and/or treatment is essential if we are to begin to address the difficult question of service effectiveness.

A longitudinal study of runaways would allow for a more thorough review of individual dispositions. Patterns of superficial adjustment to a troubled living situation, evidence of later serious anti-social behavior, and treatment methods and placements that proved to be inappropriate as well as ineffective could be more readily identified.

This study did not approach the problem of service effectiveness from the point of view of the client. Future research should take into account the opinion of runaway youth and their families concerning the type of services that were available or, in many cases, 
mandatory for runaway youth.

Development of a more definitive typology or runaway youth would require research with greater attention to socioeconomic variables, e.g., specific family income, educational levels of parents, etc. Furthermore, if theories which link runaway behavior to emotional instability are to be affirmed, discarded or modified, selected psychological testing should be performed with various runaway populations.

At the same time, the possibility should be investigated that cultural trends in social organization and shifts in value orlentations may influence runaway behavior. Measures of value divergence or conflict between parent and child, when combined with other significant varlables, could serve as a predictor of runaway prone youth. Earlier identification of potential runaways would enable truly preventative intervention.

It is our hope that this study and future research on runaways and other status offenders will initiate a reassessment of the concept of delinquency. A more complete understanding of these youth and all juvenile offenders is contingent upon removing the stigma of delinquency from behavior which is not criminally destructive. Even when dealing with seriously deviant youth, the juvenile justice labeling process may, have effects which are, in the long range, detrimental to the healthy adjustment of adolescents. Probably more important is the total community response to helping troubled individuals achieve thedr full potential.

. . We will have to create communities that break down the isolation felt by so many parents and children. We have to encourage human contact and warmth between families as well as within them. We will 65 probably have to transform the whole American ethos. 
FOOTNOTES

1. David Riley, "Runaways: And Then There Were Thousands," The Washingtonian, November, 1971 ; p. 64.

2. Statistical Report 1971--Multnomah County Juvenile Court and Donald E. Long Home, Portland, Oregon.

3. George E. Outland, "Determinants Involved in Boy Transiency," Journal of Educational Sociology, Vol. II, No. 6, February, 1938, pp. $371-72$.

4. Ibid, pp. 366-67.

5. Thomas Minehan, Boy and Girl Tramps of America, Farrer and Rinehart, New York, 1934.

6. August Aichhorn, Wayward Youth, Viking Press, New York, 1935.

7. Ibid, p. 38 .

8. Ibid, p. 41.

9. Douglas A. Thom, M.D., Normal Youth and Its Everyday Problems, D. Appleton-Century Co., New York, 1932.

10. Ibid, p. 245.

11. Amos Robey, M.D., Richard T. Rosenwalf, M.D., John E. Snel1, M.D. and Rita E. Lee, "The Runaway Girl: A Reaction to Family Stress," American Journal of Orthopsychiatry, Vol. XXIV, No. 4, July, 1964 , pp. 762-767.

12. Ibid, p. 763.

13. Dorothy C. Wylie and Joseph Weinreb, "The Treatment of a Runaway Adolescent Girl Through Treatment of the Mother," American Journal of Orthopsychiatry, Vol. XXVIII, No. 1, January 1958, pp. 188-195.

14. Dr. Frederick Rosenheim, "Techniques of Therapy," American Journal of Orthopyschiatry, October, 1940, Vol. X, pp. 651-65.

15. Ibid, p. 657.

16. Herbert Staub, "A Runaway from Home," Psychoanalytic Quarterly, 12 (1): 1943, pp. 1-22.

17. Lawson G. Lowrey, "Runaways and Nomads," American Journal of Orthopsychiatry, Vol. XI, No. 4, October, 1941, pp. 775-783.

18. Ibid, p. 781.

19. Ibid, p. 777. 
20. Leo Kanner, M.D., Child Psychiatry, Charles C. Thomas, publisher,
2nd ed., 1950.

21. Ibid, pp. 697-98.

22. Morris D. Reimer, "Runaway Children," American Journal of Orthopsychiatry, Vol. $X$, July, 1940, p. 522.

23. Ibid, pp. 522-23.

24. Ibid, p. 523.

25. Ibid, p. 525 .

26. Randa11 M. Foster, M.D., "Intrapsychic and Environmental Factors in Running Away from Home," American Journal of Orthopsychiatry, Vol. XXXII, No. 3, Apri1, 1962, pp. 486-91.

27. Ibid, p. 491.

28. Theodore Leventhal, "Inner Control Deficiencies in Runaway Children," Archives of General Psychiatry, Vol II, August, 1964, pp. 170-76.

29. Ibid, p. 170.

30. Ibid, p. 175.

31. Ibid, p. 175.

32. Ibid, p. 172-173.

33. Joseph E. Paull, "The Runaway Foster Child," Child Welfare, July, 1956, pp. 21-26.

34. Lawrence S. Bradshaw, et a1, Runaway Youth in Salt Lake County, unpublished Masters Thes is, University of Utah, June, 1969.

35. James A. Hildebrand, "Why Runaways Leave Home," The Journal of Criminal Law, Criminology and Police Science, Northwestern University School of Law, Vo1. 54, No. 2, June, 1963, pp. 211-16.

36. Ivan Nye and James F. Short, Jr., "Scaling Delinquent Behavior," American Sociological Review, June 1957, pp. 326-31.

37. Lee N. Robins, "Mental Illness and the Runaway--A 30 Year Followup Study," Human Organization, Winter, 1958, pp. 11-15.

38, Ibid, p. 13.

39. Lee N. Robins and Patricia O'Neal, "The Adult Prognosis for Runaway Children," American Journal of Orthopsychiatry, Vol. XXIX, No. 4, October, 1959, pp. 752-61. 
40. Ibid, pp. 760-61.

41. Robert Shellow, Julianna R. Schamp. Elliot Liebow, and Elizabeth Unger, Suburban Runaways of the 1960's, Society for Research in Child Development, Chicago, 1967.

42. Ibid, p. 21.

43. Ibid, p. 28.

44. Rev. Larry Beggs, Huckleberry's for Runaways, Bal lantine Books, New York, 1969.

45. David Riley, "Runaways: And Then There Were Thousands," The Washingtonian, November, 1971, pp. 64-73.

46. Ibid, p. 123.

47. Jane Whitbread, "Runaways: Greenwich Village Case Histories," Look, July. 25, 1967, pp. 26-32.

48. Lawrence Bradshaw, et al, Runaway Youth in Salt Lake County, University of Utah, June, 1969, p. 41.

49. David Riley, "Runaways: Then There Were Thousands," The Washingtonian, November, 1971, Vol. 7, No. 2, p. 66.

50. Male referrals, 761 ; female referrals, 1204 ; total runaway referrals 1,965. 1971 Multnomah County Juvenile Court Statistical

Report, p. 8.

51. Portland Public Schools' Annual Report, 1970-71, (unpublished at the time of this study; data provided by administrative staff.)

52. James A. Hildebrand, "Why Runaways Leave Home," Journal of Criminal Law, Criminology and Poltce Science, LIV, June, 1963, pp. 221-226.

53. Lawrence S. Bradshaw, et. al., Runaway Youth in Salt Lake County, University of Utah, June, $19 \overline{969}, \bar{p}, 36$.

54. "Runaway Kids," Life, LXIII, November, 1967, p. 18.

55. Census Population \& Housing, CRAG, June, 1971, p. 1.

56. Vital Statistics, Oregon State Health, 1971.

57. Lawrence S. Bradshaw, et. al., Runaways in Salt Lake County, p. 41.

58. Douglas A. Thom, 1932, Normal Youth and Its Everyday Problems,

D. Appleton-Century Co., New York, 1932. 
59. Robert Shellow, et al, Suburban Runaways of the 1960's, Society For Research in Chitd Development, Chicago, 1967, p. T9.

60. Rev. Larry Beggs, Huckleberry's for Runaways, Ballantine Books, New York, 1969, p. 12 .

61. Lawrence S. Bradwhaw, et al, Runaway Youth in Salt Lake County, University of Utah, June, 1969, p. 65 .

62. Ibid, p. 57.

63. Lee N. Robins and Patricia 0'Neal, "The Adult Prognosis for Runaway Children," American Journal of Orthopsychiatry, Vol. XXIX, No. 4, October, 1959, pp. 752-761.

64. Ivan Nye and James F. Short, Jr., "Scaling Del inquent Behavior," American Sociological Review, June, 1957, pp. 326-333.

65. David Riley, "Runaways: Then There Were Thousands," The Washingtonian, November, 1971, p. 71. 
APPENDIX A

INTERVIEW FORM

1st COURT QUESTIONNAIRE

Court \#

Date

Sex Race Birthdate Age Are you living at home? Yes No If not, with whom?

Check ( ) parents' marital status: Married Divorced Separated

Check ( ) who has legal custory: Parents Court Relative

other

Number of siblings: Brothers Sisters No. at home

Your position in family: 01 dest Middle Youngest

Is family receiving welfare? Yes No

How were you referred to the court? Parents Police School

Other

Have you been referred to court before? Yes No

What kind of help would you like to receive from the court?

School Grade level Have you ever been in any trouble at school? If so, what?

Were you attending school at the time you ran away? Yes No

If not, were you: expelled suspended dropped out How do you feel about school? (indicate attitude and degree of emotion) Have you ever run away before? Yes__ No _ If yes, how many times? Did you run away alone or w/others? If w/others, how many?

How long have you been away from home, guardian, or foster home? 
What happened just before you decided to run?

(probe for critical incident)

What did you like most about running away?

(probe for single thing liked most)

What did you dislike most about running away?

(probe for single thing disliked most)

How do you feel about your parents/guardian?

(Indfcate attitude \& degree of emotion)

How do you think your parents/guardian feel toward you? How do you feel toward other famtly members?

(indicate attitude \& degree of emotion)

How do you think other family members feel toward you? What adults would you talk to about important things? (parents, relatives, etc.)

Do you have any close friendships? (Not family)

If so, how many?

Where were you going when you ran away?

How do you feel about going home?

Indicate with * next to subject which is of greatest conflict between yourself and parents. Write next to each subject whether you decide it or your parents.

Clothes Hair Where to go Hours

Friends Drugs Cigarettes School

How are conflicts usually settled? Parents decide You decide Decided on democratic basis 
Disposition: (appropriate code)

Placement: (appropriate code)

01 Remand

(CHGE NOT SUBSTNTD)

02 Found not inv by cnsir

03 Dismissed at ct hearing

(CHARGE SUBSTNTD NO HEARING)

04 Handled concrntly/other refrl

$05 \mathrm{Warn} / \mathrm{close}$ or child disaprd

06 Place on informl suprvision

07 Cont on informl suprv

08 Cont on form 1 probn

09 Ret to (spcfy via item 10)

10 Ret to other jrsdn

11 Rfrd to other court, agency/ indiv

12 Suprvn, ct. dep

13 Suprvn, wifr, dep

14 Suprvn, other, dep
(CHARGE SUBSTNTD AT HEARING)

15 Handled cocrntly/other refrl

16 Dismissed

17 Place on forml probn

18 Cont on forml probn

19 Suspnd commt

20 Revoke suspnd cmmt (spcfy via item 10)

21 Commtd to (spcfy via item 10)

22 Rtrnd to (spcfy via 1 tem 10)

23 Rtrnd to other jrsdn

24 Suprvn, ct, dep

25 Suprvn, wlfr, dep

26 Suprun, other, dep

(SPECIAL PROCEEDINGS)

27 Term/prntl rights

28 Perm commt/prntl rights (via

29 Other item 10)

Counselor's comments: (Please specify who made the dispositional plan and what type of treatment or service was given.) 
APPENDIX B

PRELIMINARY SURVEY

CONTACT INTERVIEW FORM

Name

Date

Home address

Phone

city, state

Parents address Phone city, state

Sex Birthdate Age Birthplace Race

Parents Marital Status (Married, Divorced, etc.) Your Legal Custody (Parents, Court, etc.)

Number of siblings: Brothers Sisters No. living at home

Your position in the family: 01dest Youngest Middle

Is family receiving welfare? Yes _ No If yes, caseworker

Have you ever been to Juvenile Court? Yes No If yes, why?

If applicable, why did you come to Portland area?

(Friends, Relatives, City action)

How did you hear about Contact Center?

(Friends, Paper, Other agency, etc.)

Why did you come to Contact Center?

(To get help, curiosity, etc.)

What kind of help do you want from Contact?

(Housing, counseling, information, etc.)

School last attended Grade level Have you ever been in any serious trouble at school? If so, what?

Were you attending school at the time you ran away? Yes_ No___ If no, were you expelled suspended dropped out

How do you feel about school? 
What are your immediate plans?

(Return home, find fos ter care, travel, etc.)

What are your future plans?

(Find job, travel, go to school, etc.)

Interviewer 


\section{RUNAWAY INFORMATION}

Have you ever run away before? Yes No If yes, how many times?

Did you run away alone or with others? If with others, how many?

How long have you been away from home? (parents home) (if applicabTe)

What happened just before you decided to run?

(fight with parents, kicked out, etc.)

What did you like about running away?

(freedom, travel, no fights, etc.)

What don't you like about running away?

(loneliness, no economic support, etc.)

How do you feel toward your parents/guardian?

(indicate attitude and degree of emotion)

How do parents/guardian feel toward you?

(indicate attitude and degree of emotion)

How do you feel toward other family members?

(indicate attitude and degree of emotion)

How do other family members feel toward you?

(indicate attitude and degree of emotion)

What adults would you talk to about important things?

(parents, relatives, etc.)

Do you have any close friendships? (not family) If so, how many?

Where were you going when you ran away? (to see friends, didn't know, etc.)

Did you know about Contact Center before you ran away? Yes_ No Why don't you want to go home now? (indicate factors runaway wants changed)

Who usually decides questions about the following matters? Indicate with * next to subject which is of greatest conflict.

Clothes Hair Where you go Hours Friends Drugs 
Interviewer's comments: any information regarding impressions, recommendations for helping this person, and reason for the runaway. 


\section{DISPOSITION AND REFERRAL SHEET}

Client Status (runaway, crasher, street person, etc.)

Phone clearance with (name of person)

Outcome of parent/guardian contact

(indicate general response and attitude)

Legal waiver sent__ By Date Received

Services Provided Date

Housing

Information

Counseling

Medical

Family session

Lega 1

Food

Financial

Transportation

other

Disposition (returned home, foster home, community agency, remained on street, etc.):

Client impression of help received from Contact (indicate attitude and emotion):

Client departure date Client destination

Worker comments (Please include any follow-up or information about client): 


\author{
APPENDIX C \\ PRELIMINARY SURVEY \\ CONTROL QUESTIONNAIRE
}

Date

Sex Birthdate Age

Check ( ) parents' marital status: Married Separated Divorced Check ( ) who has legal custody: Parents Court _ Other

No. of siblings: Brothers Sisters No. at home

Your position in the family: 01dest Middle Youngest

Is your family receiving welfare? Yes No Have you ever been to juvenile court? Yes No

If yes, why?

School Grade level Have you ever been in any trouble at school? Yes No If yes, what?

How do you feel about school?

How do you feel toward your parents/guardian?

How do you think your parents/guardian feel toward you?

How do you feel toward other family members?

How do you think other family members feel toward you?

What adults would you talk to about important things?

Do you have any close friendships? If so, how many? Indicate with * next to subject which is of greatest conflict between yourself and parents: write next to each subject whether you decide it or your parents.

Clothes Hair Where you go Hours

Friends Drugs Cigarettes School 
How are conflicts usually settled? Parents decide You decide Decided on democratic basis

Have you ever been away from home for 24 hours or more without parental consent? Yes No

If you have been away from home for more than 24 hours, was there an agency involved? Yes No

What agency? Welfare Juvenile Court Contact Center

If you have never been away from home wi thout parental consent, have you ever considered it? Yes No If yes, why did you decide against it? 
APPENDIX D

MULTNOMAH COUNTY JUVENILE COURT

RUNAWAY FORM

Name Date

Home Address Phone

(City, State)

Sex Birthdate Age _ Race

Check the status of your natural (biological) parents;

1. Stil1 Married

4. Widowed

2. Separated

5. Never Married

3. Divorced

6. Don't know

If \#3 or \#4 above, approximately how many years ago did this occur?

Check the people you were living with before you ran away; and specify the number of brothers and sisters present:

$\begin{array}{ll}\text { Natural Mother } & \text { Natural Brothers } \\ \text { Natural Father } & \text { Natural Sisters } \\ \text { Stepmother } & \text { Step-Brothers } \\ \text { Stepfather } & \text { Step-Sisters } \\ \text { Foster Parents } & \text { Half-Brothers } \\ \text { Relatives } & \text { Half-Sisters } \\ \text { Institution } & \text { Foster Siblings }\end{array}$

If not living with natural parents, who has your legal custody?

Natural Mother

Natural Father

Relatives
Welfare

Juv. Court

Other

If not living with either natural parent, check the frequency which you generally visit them: 
Mother: Often__ Occasionally_ Seldom_ Not at all__

Father: Often__ Occasionally_ Seldom_ Not at all__

How long have you been on the run?

What happened just before you decided to run?

(fight w/parents, kicked out, etc.)

Have you ever run away before? Yes__ No__ If yes, how many times?

Have you ever been to Juvenile Court? Yes__ No__ If yes, why?

School last attended Grade Level__ Have you ever been

in any serious trouble at school? If yes, what?

Circle the number which most closely represents your feelings about school:

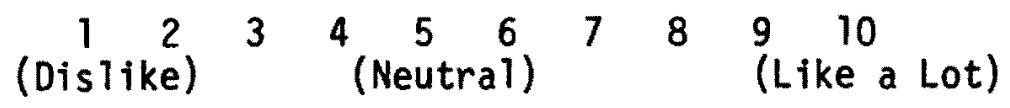

Circle the number which most closely represents your feelings about the parents (or institution) that you are living with:

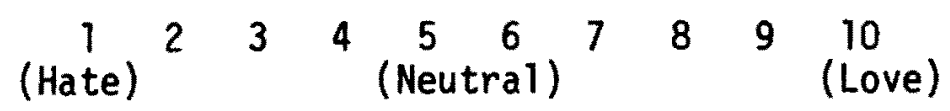

Circle the number which most closely represents how much YOU TRUST your parents :

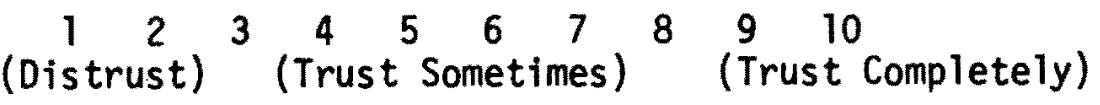

Circle the number which most closely represents the feelings of your parents (whom you lived wi th) toward you:

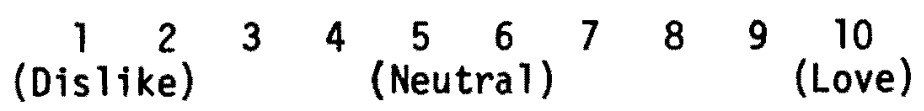

Circle the number which most closely represents how much YOUR PARENTS TRUST you:

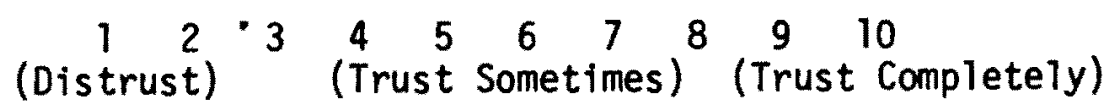

If applicable, how do your parents treat you in relation to your brothers and/or sisters whom you live with?

$$
\text { About Same__ Better__ Worse }
$$

Your position is the family: 01dest__ Youngest__ Middle Are there any adults with whom you can discuss important matters and problems privately?

Yes

No 
APPENDIX E

CONTACT CENTER RUNAWAY FORM

Name Date

Home Address Phone

(City, State)

Parents Name Father Occupation (Parents you live with) (If no father, ist mother) Parents Address Phone (City, State) Sex Birthdate Age Race

Check the status of your natural (biological) parents:

1. Still married

4. Widowed

2. Separated

5. Never married

3. Divorced

If \#3 or \#4 above, approximately how many years ago did this occur?

Check the people you were living with before you ran away; and specify the number of brothers and sisters present:

Natural Mother

Natural Brothers

Natural Father

Natural Sisters

Step-Mother

Step-Brothers

Step-Father

Step-Sisters

Foster Parents

Half-Brothers

Relatives

Half-Sisters

Institution

Foster Siblings

If not living with natural parents who has your legal custody?

Natural Mother

Natural Father

Relatives
Welfare

Juv. Court

Other 
Is the family you were living with receiving welfare? Yes No

If yes, 11st County and Caseworker: County

Caseworker

If not living with either natural parent, check the frequency which you generally visit them:

Mother: Often Occastonally Seldom Not at all

Father: often Occastonally Seldom Not at all

How long have you been on the run?

What happened just before you decided to run?

(Fight w/parents, kicked out, etc.)

Have you ever run away before? Yes No If yes, how many times? Have you ever been to Juvenile Court? Yes No If yes, why?

School last attended Grade Leve1 Have you ever been in any serious trouble at school? If yes, what?

Circle the number which most closely represents your feelings about schoot:

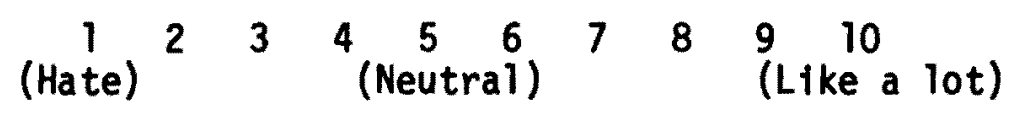

Circle the number which most closely represents your feelings about the parents (or institution) that you are living with:

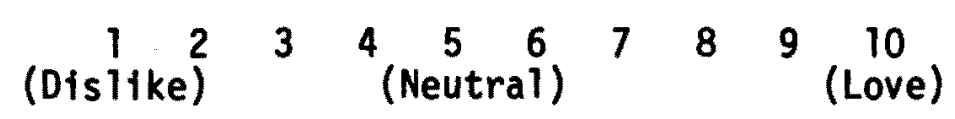

Circle the number which most closely represents how much you trust your parents:

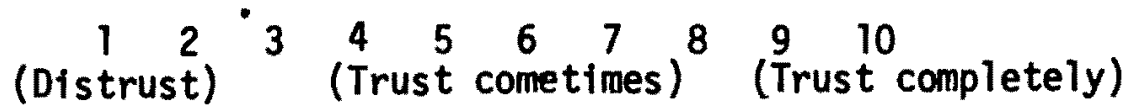

Circle the number which most closely represents the feelings of your parents (who you lived with) toward you:

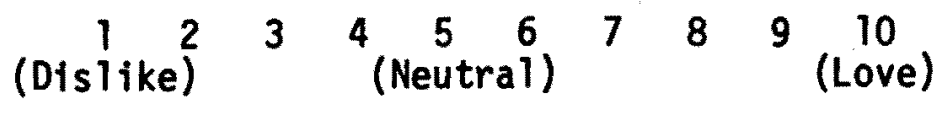


Circle the number which most closely represents how much your parents trust you:

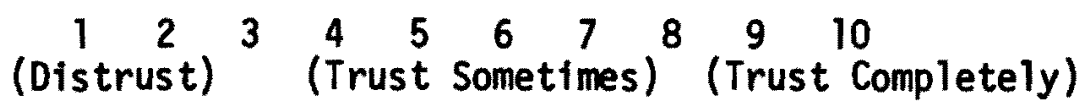

If applicable, how do your parents treat you in relation to your brothers and/or sisters who you live with?

About Same

$$
\text { Better }
$$

Worse

Your position in the family: 01dest Youngest Middle

Are there any adults who you can discuss important matters and problems with privately?

Yes No 
APPENDIX $F$

QUESTIONNAIRE

CONTROL

Date Age Birthdate

Sex: Male Female

Race: White Black Oriental

Check the status of your natural (biological) parents:

1. Still Married

2. Separated

3. Divorced
4. Widowed

5. Never Married

6. Don't know

If \#3 or \#4 above, approximately how many years ago did this occur?

Check the people you are presently living with; and specify the number of brothers and sisters present:

$\begin{array}{ll}\text { Natural Mother } & \text { Natural Brothers } \\ \text { Natural Father } & \text { Natural Sisters } \\ \text { Stepmother } & \text { Step-Brothers } \\ \text { Stepfather } & \text { Step-Sisters } \\ \text { Foster Parents } & \text { Half-Brothers } \\ \text { Relatives } & \text { Half-Sisters } \\ \text { Institution } & \text { Foster Siblings }\end{array}$

If not living with natural parents, who has your legal custody?

$\begin{array}{ll}\text { Natural Mother } & \text { Welfare } \\ \text { Natural Father } & \text { Juv. Court } \\ \text { Relatives } & \text { Other }\end{array}$

If not living with either natural parent, check the frequency which you generally visit them:

Mother: Often Occasionally Seldom Not at all

Father: Often Occasionally Seldom Not at all

Have you ever run away from home? Yes No 
If yes, how many times?

Have you ever been to Juvenile Court? Yes No

If yes, why?

School attending any sertous troub $\bar{T}$ at school? Yes Grade Have you ever been in No_If yes, what?

Circle the number which most closely represents your feelings about schoot.

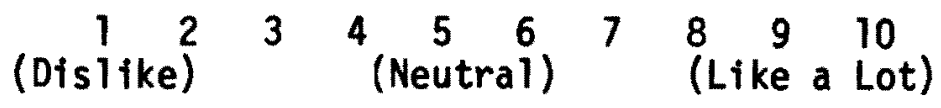

Circle the number which most closely represents your feelings about the parents (or institution) that you are living with:

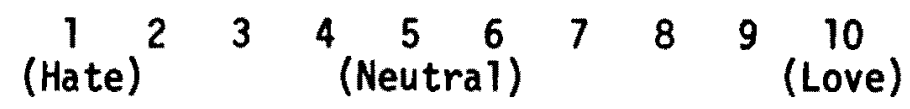

Circle the number which most closely represents how much YOU TRUST your parents.

$$
\begin{array}{ccccccc}
1 & 2 \\
\text { (Distrust) } & 3 & 4 & 5 & 6 & 7 & 8 \\
\text { (Trust Sometimes) } & 8 & 9 & 9 \\
\text { (Trust Completely) }
\end{array}
$$

Circle the number which most closely represents the feelings of your parents (whom you live with) toward you:

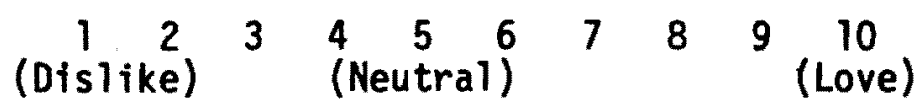

Circle the number which most closely represents how much YOUR PARENTS TRUST you:

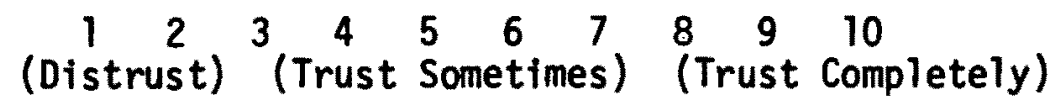

If applicable, how do your parents treat you in relation to your brothers and/or sisters whom you live with?

About Same

Better

Worse

Your position in the family: 01dest Youngest Middle

Are there any adults with whom you can discuss important matters and problems privately?

Yes No 
APPENDIX $G$

Frequency Tabulation Tables of Independent Variable for

Second Questionnatre

Independent

Variable

Contact Court Control Non-Chronic Chronic

Sex

1. Male

2. Female Total

$\begin{array}{rrr}6 & 22 & 22 \\ \frac{15}{21} & \frac{28}{50} & \frac{12}{34}\end{array}$

14

14

$\frac{21}{35}$

$\frac{22}{36}$

\section{Race}

1. B1ack

2. Indfan

3. Caucasian

4. Oriental

5. Mixed

6. Other or no answer Total

$\begin{array}{rrr}0 & 3 & 0 \\ 0 & 2 & 0 \\ 19 & 38 & 31 \\ 0 & 1 & 3 \\ 0 & 2 & 0 \\ 2 & 4 & 0 \\ \frac{2}{21} & 50 & \frac{1}{34}\end{array}$

Age

1. 12

2. 13

3. 14

4. 15

5. 16

6. 17

7. 18

Total

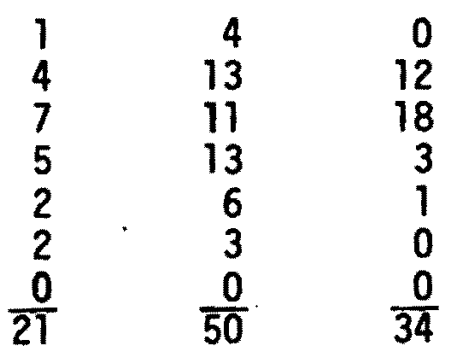

1
4
9
14
5
2
0
$\frac{0}{35}$

4
13

Not Computed

Grade Level in

School

1. $\frac{\text { 7chool }}{7-8}$

2. $9-10$

3. $11-12$

4. No answer Total

Address

1. Portland area

2. Oregon

3. Out of State Total

\begin{tabular}{rrr}
5 & 13 & 0 \\
7 & 27 & 33 \\
5 & 9 & 1 \\
4 & 1 & 0 \\
\hline 21 & 50 & $\frac{1}{34}$
\end{tabular}

18

27

$\frac{1}{21}$

$\frac{13}{50}$
34

0 $\begin{array}{ll}7 & 0 \\ 3 & \frac{0}{34}\end{array}$

3034
Not Computed 
Parents' Marital

\section{Status}

1. Stili Married

2. Separated

3. Divorced

4. Widowed

5. Never Married

6. Don't know Total

12
0
6
0
2
1
21

$\begin{array}{rr}19 & 22 \\ 4 & 0 \\ 20 & 9 \\ 4 & 2 \\ 3 & 0 \\ 0 & 1 \\ 50 & 34\end{array}$

14

2

16

3

$\frac{0}{36}$

$$
\begin{aligned}
& 14 \\
& 2 \\
& 16 \\
& 3 \\
& 1 \\
& 0 \\
& \hline 6
\end{aligned}
$$

Length of Time Separated or Divorced

1. Less than 1 year 0

$0 \quad 0$

$\begin{array}{rr}5 & 2 \\ 10 & 5\end{array}$

3. More than 5 years 1

$22 \quad 22$

17
2
10
1
4
1
35

17
2
10
1
4
1
35

17
2
10
1
4
1
35

4. Not applicable 14

5. No answer or don't know Total

$\frac{4}{21}$

$\frac{13}{50}$

$\begin{array}{rr}0 & 0 \\ 3 & 4 \\ 4 & 7 \\ 21 & 15 \\ \frac{7}{35} & \frac{10}{36}\end{array}$

Who Subject Was

Living With Be-

fore Running

Away

1. Natural Mother

2. Natural Father

3. Both 1 and 2 .

4. Stepmother

5. Stepfather

6. Both 4 and 5 .

1
0

5

5

13

10

0

0

0

0

0

$\frac{5}{34}$

$\frac{10}{36}$

7. Natural Mother and stepfather 4

8. Natural Father and stepmother

9. Foster Parents

10. Relatives

11. Institutions

12. Other Total

0

रो

9

$\begin{array}{rl}5 & 1 \\ 2 & 1 \\ 14 & 9 \\ 0 & 0 \\ 0 & 0 \\ 1 & 0\end{array}$

4

4
6

30

$7 \quad 0$

$\frac{0}{50}$

$\frac{0}{34}$

$\begin{array}{rr}6 & 7 \\ 1 & 4 \\ 5 & 5 \\ 1 & 2 \\ 0 & 7 \\ 0 & 0 \\ \frac{0}{35} & \frac{0}{36}\end{array}$

Legal Custody if not Living with Either Natural Parent

1. Natural Mother

2. Natural Father

3. Both 1 and 2

4. Relatives

$\begin{array}{ll}4 & 9 \\ 0 & \\ 0 & \\ 0 & 2\end{array}$

9
6
2
2

6
2
0
0

4 


\begin{tabular}{rr}
1 & 2 \\
5 & 13 \\
1 & 1 \\
10 & 15 \\
\hline 21 & $\frac{15}{50}$
\end{tabular}

5. Welfare

6. Juvenile Court

2
13

1

8. Not Applicable Total
How Subject Feels About Parents (or Institution $\mathrm{He}$ is Living With

(Hate)
2
3
4
5
6
7
8
9
10 (Love)

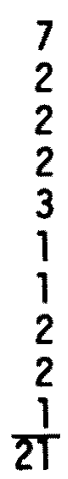

No. of Stblings

Subject Living With

Before Running Away

1. Natural Brothers

2. Natural Sisters

46

43

2
4

1

0

0

$\frac{26}{34}$

$\frac{2}{14}$

$\frac{11}{36}$

60

38

37

22

38

3. Step Brothers

10

6

13

12

8
13

Step Sisters

1

5. Half-Brothers

3

1

13

6. Half-Sisters

0

7. Foster Stblings

$\frac{10}{50}$

2
24 Total

$\frac{24}{159}$

$\frac{0}{104}$

$\begin{array}{r}6 \\ 1 \\ 21 \\ \hline 109\end{array}$

Ordinal Position
1. Oldest
2. Middle
4. Not Applicable
Total

8

8

17

7

10

15

23

18

$\frac{1}{21}$

$\frac{0}{50}$

9

16

15

$\frac{0}{34}$

8

6

$\frac{1}{35}$

$\frac{0}{36}$

How Subject Views

Parental Treatment

Iwd Self in RItn

to Siblings

1. About the Same

6

27
3
19
1
0
50

27
3
2
2
0
34

16

17

2. Better

0

3. Worse

4. Not Applifcable

5. Different Total 
Independent

Variable

Contact Court Control Non-Chronic Chronic

How Subject Feels

That His Parents

Trust Him
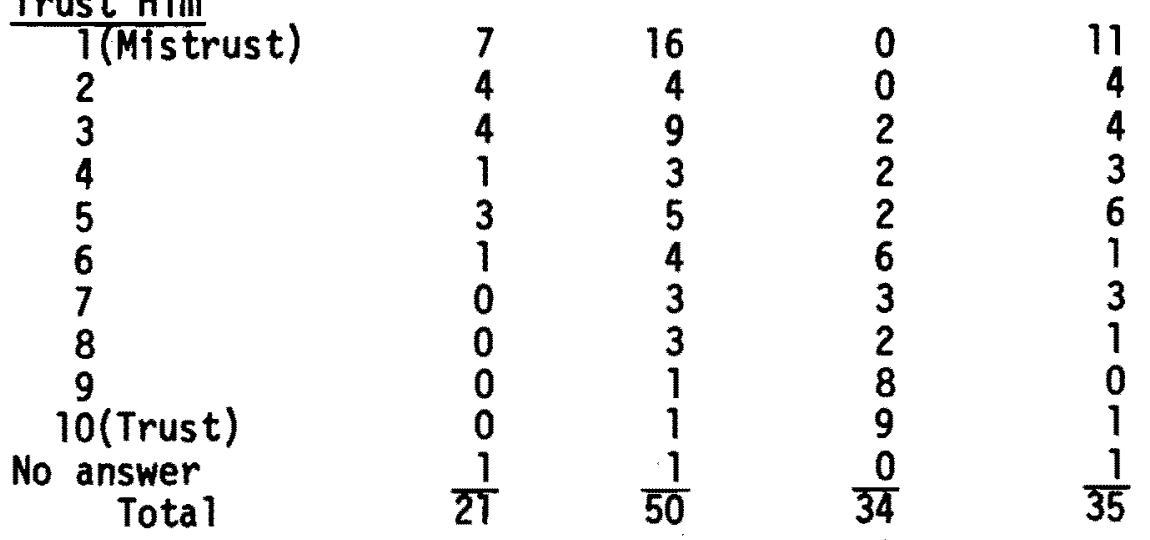

12
4
9
1
2
4
0
2
1
0
1
$\frac{36}{36}$

How Subject Trusts

Parents
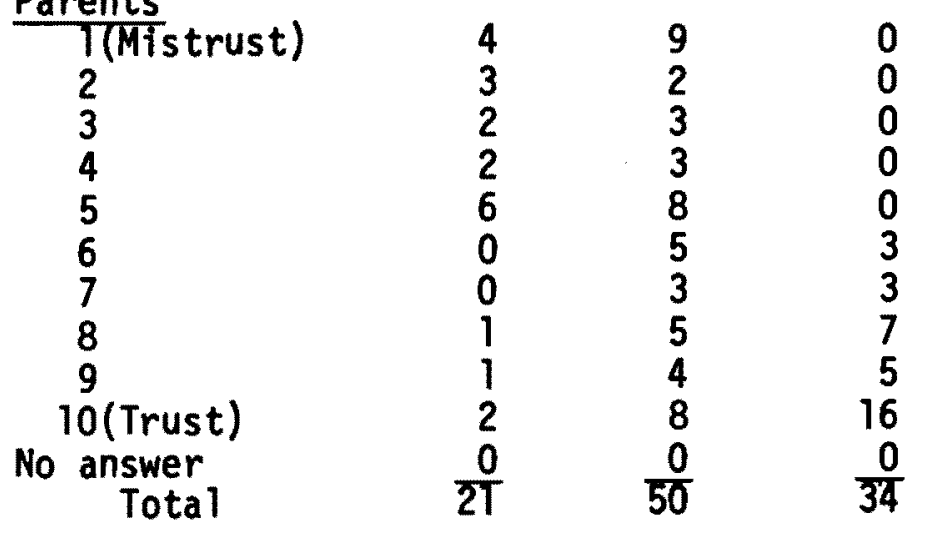

5
3
4
3
7
3
1
1
2
6
1
36

How Subject Views

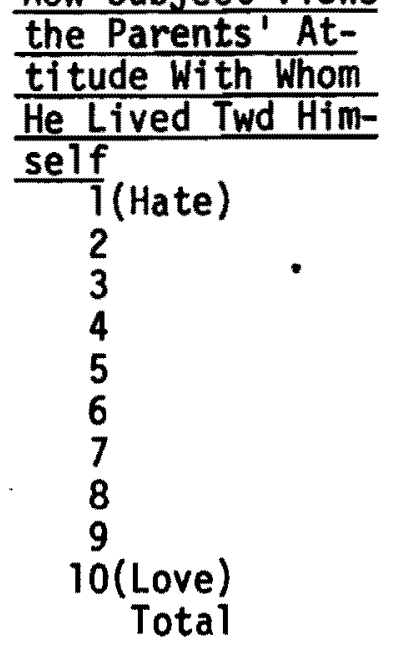

$\begin{array}{rrrrr}3 & 3 & 0 & 2 & 4 \\ 0 & 1 & 0 & 1 & 0 \\ 2 & 2 & 0 & 3 & 1 \\ 3 & 5 & 1 & 5 & 3 \\ 4 & 6 & 2 & 4 & 6 \\ 2 & 10 & 0 & 4 & 7 \\ 2 & 4 & 2 & 4 & 2 \\ 1 & 4 & 0 & 2 & 3 \\ 2 & 2 & 7 & 2 & 2 \\ 2 & 13 & \frac{22}{34} & \frac{7}{34} & \frac{8}{36}\end{array}$


Independent

Variable

Contact Court Control Non-Chronic

Chronic

Any Adults With

Whom Important

Matters Can be

Discussed

1. Yes

2. No

3. Other (someone

$11 \quad 29$

$8 \quad 19$

23

24

16

11

18

other than an adult)

$2 \quad 2$

$\underline{0}$

Total

21

50

34

36

How Long Was Sub-

ject on the Run

1. Less Than 1 Week 14

2. 1 to 2 Weeks

29 Not

7 Applic.

21

22

3. More Than 2 But Less Than 4 Weeks

4. One Month or More 1

5. Other or no answer 2 Total

35

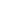
Total

Has Subject Ever Run

$\frac{\text { Away Before }}{\text { No }}$

Yes, \# of Times

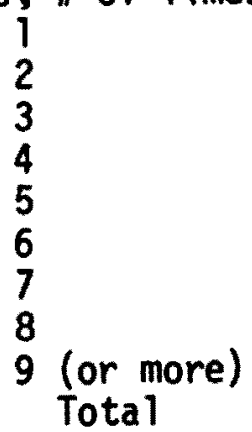

6

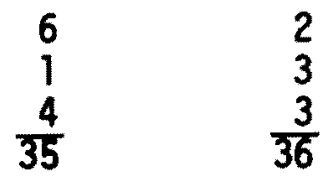

Not Computed

Has Subject Eyer Been

To Juvenfle Court

1. Yes

2. No

Total
$12 \quad 36$

$\frac{9}{21}$

$\frac{14}{50}$

16
$\frac{19}{35}$

32

0
34
34

$\frac{4}{36}$

If Subject Has Been to Juventle Court, Why

1. Runaway

24

0

22

2. Truancy

3. Drugs

4. Curfew 
Independent

Variable

Contact

Court Control

Non-Chronic Chronic

5. Theft or Shopilfting

6. Drinking

7. Variety

8. Other (Includes no answer)

9. Not Applicable

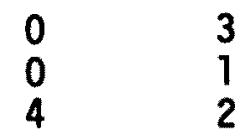

0

0

2

0

\begin{tabular}{rr}
4 & 4 \\
9 & 14 \\
\hline 21 & $\frac{14}{50}$
\end{tabular}

0
$\frac{34}{34}$

5

What Happened to

Subject Before

Decision to Run

1. Fight With Parents or Unhappy Home

Situation

2. Fight With Siblings

8

25

Not

16

17

Applic.

3. Change in Marital

Status of Prnts.

1

2

2

4. Kicked out

$\begin{array}{rr}1 & 1 \\ 1 & 2 \\ 1 & 3 \\ 0 & 7 \\ 5 & 9 \\ \frac{4}{21} & \frac{1}{30}\end{array}$

1

1
$\frac{4}{36}$

5. Law Violation

6. Nothing Specific

7. Other

8. No answer Total

Has Subject Been in

Trouble at School

1. Yes

2. No

8

3. Not Applicable

(out of school)

Total

12

$\frac{1}{21}$

If Trouble in School,

What Kind of Trouble

1. Truant

2. Assault

3. Bkg. School Rules 1

4. Expelled . 4

5. Drugs

6. Other 7. Not Applicable $\frac{13}{2 T}$
Tota1
21

28

$\frac{1}{50}$
5
29

12

23

$\frac{0}{35}$

$\frac{0}{34}$

How Subject Feels

About School

T(Distike)

17

17

1

3

3

5

$\frac{2}{35}$

$\frac{3}{36}$

2

6

14

0
0

3

0 


\section{Independent}

Variable

\section{Contact}

Court Control

Non-Chronic Chronic

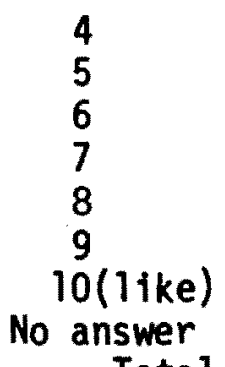

Total

$\begin{array}{rr}3 & 5 \\ 3 & 9 \\ 1 & 7 \\ 1 & 3 \\ 1 & 1 \\ 0 & 1 \\ 2 & 3 \\ 1 & 1 \\ \text { 21 } & 50\end{array}$

$\begin{array}{r}2 \\ 7 \\ 9 \\ 3 \\ 5 \\ 4 \\ 2 \\ 0 \\ \hline 34\end{array}$

4
7
3
4
0
1
1
$\frac{1}{35}$

4

9

5

$7 \quad 9$

5

15

0

1

2

0

4

$\frac{1}{36}$

If Not Living With

Natural Parents, How often Visits Mother

1. Often

2. Occasiona 11y

0

7
7
4
2

0

0

0

3. Seldom

4. Not at all

0

1

$\frac{16}{21}$

$\frac{30}{50}$

$\frac{33}{34}$

1
3
2
2

2

3

4 or no answer Total

21

$\frac{27}{35}$

$\frac{23}{36}$

If Not Living With

Natural Parents, How Often Visits Father

1. Often

2. Occasionally

3. Seldom

4. Not at all

5. Not Applicable or no answer Total

0

0

4

0

$\frac{17}{21}$

Is Family Receiving

Welfare

1. Yes

2. No

3. No answer Total
1
1
6
2

2

3
4

6

6

0

$\frac{31}{50}$

$\frac{33}{34}$

$\frac{25}{35}$

$\frac{23}{36}$ 
BIBL IOGRAPHY

Afchhorn, August, Wayward Youth, Viking Press, New York, 1935.

Beggs, Larry Rev., Huckleberry's for Runaways, Ballantine Books, New York, 1969.

Bradshaw, Lawrence Stuart, et al, Runaway Youth in Salt Lake County, unpublished Masters Thesis, University of Utah, June 1969.

Census Population and Housing, CRAG, June 1971, p. 1.

Foster, Randall M., M.D., "Intrapsychic and Environmental Factors in Running Away from Home," American Journal of Orthopsychiatry, Vol. XXXII, No. 3, Apr11 1962, pp. 486-491.

Hildebrand, James A., "Why Runaways Leave Home," The Journal of Criminal Law, Criminology, and Police Science, Northwestern University School of Law, Vo1. 54, No. 2, June 1963, pp. 211-216.

Kanner, Leo, M.D., Child Psychiatry, Charles C. Thomas, publisher, 2nd Edition, 1950.

Leventha1, Theodore, "Inner Control Deficiencies in Runaway Children," Archives of General Psychiatry, Vol. II, August 1964, Pp. 70-76.

Lowrey, Lawson G. , "Runaways and Nomads," American Journal of Orthopsych fatry, Vol. XI, No. 4, October 1941, pp. 775-783.

Minehan, Thomas, Boy and Girl Tramps of America, Farrer and Rinehart, New York, 1934.

1971 Multnomah County Juvenile Court Statistical Report, p. 8.

Nye, F. Ivan, and James F. Short, "Scaling Delinquent Behavior," American Sociological Review, June 1957, p. 326-331.

Outland, George E., "Determinants Involved in Boy Transciency," Journal of Educational Sociology, Vol. II, No. 6, February 1938, p. $361-372$.

Paul1, Joseph E., "The Runaway Foster Child," Child Welfare, July 1956, pp. 21-26.

Portland Public Schools' Annual Report, 1970-71 (unpublished).

Reimer, Morris D., "Runaway Children," American Journal of Orthopsychiatry, Vol. X, July 1940, pp. 522-526. 
Riley, David, "Runaways: And Then There Were Thousands," The Washingtonian, November 1971, pp. 64-73.

Robey, Amos, M.D.; Richard J. Rosenwald, M.D.; John E. Snell, M.D.; and Rita E. Lee, "The Runaway Girl: A Reaction to Family Stress," American Journal of Orthospychiatry, Vol. XXXIV, No. 4, July 1964, p. 762-767.

Robins, Lee N., "Mental Illness and the Runaway--A 30-Year FollowUp Study," Human Organization, Vo1. 16, No. 4, Winter 1958, p. 11-15.

Robins, Lee N., Ph.D., and Patricia O'Neal, M.D., "The Adult Prognosis for Runaway Children," American Journal of Orthopsychiatry, Vol. XXIX, No. 4, October 1959, pp. 752-761.

Rosenheim, Dr. Frederick, "Techniques of Therapy," American Journal of Orthopsychiatry, October 1940, Vol. X, pp. 651-665.

Shellow, Robert; Juliana R. Schamp; Elliot Liebow; and Elizabeth Unger, Suburban Runaways of the 1960's, Society for Research in Development Monography, Vol. 32, No. 3, Chicago, 1967.

Staub, Herbert, "A Runaway From Home," Psychoanalytic Quarterly, Vol. 12, No. 1, 1943, pp. 1-22.

Thom, Douglas A., M.D., Normal Youth and Its Everyday Problems, D. Appleton-Century Co, New York, 1932.

Vital Statistics, Oregon State Board of Health, 1971.

Whitbread, Jane, "Runaways," Look, July 25, 1967, p. 26-32.

Wylie, Dorothy C. and Joseph Weinreb, "The Treatment of a Runaway Adolescent Girl Through Treatment of the Mother," American Journal of Orthopsychiatry, Vol. XXVIII, No. 1, January 1958, p. 188-195. 